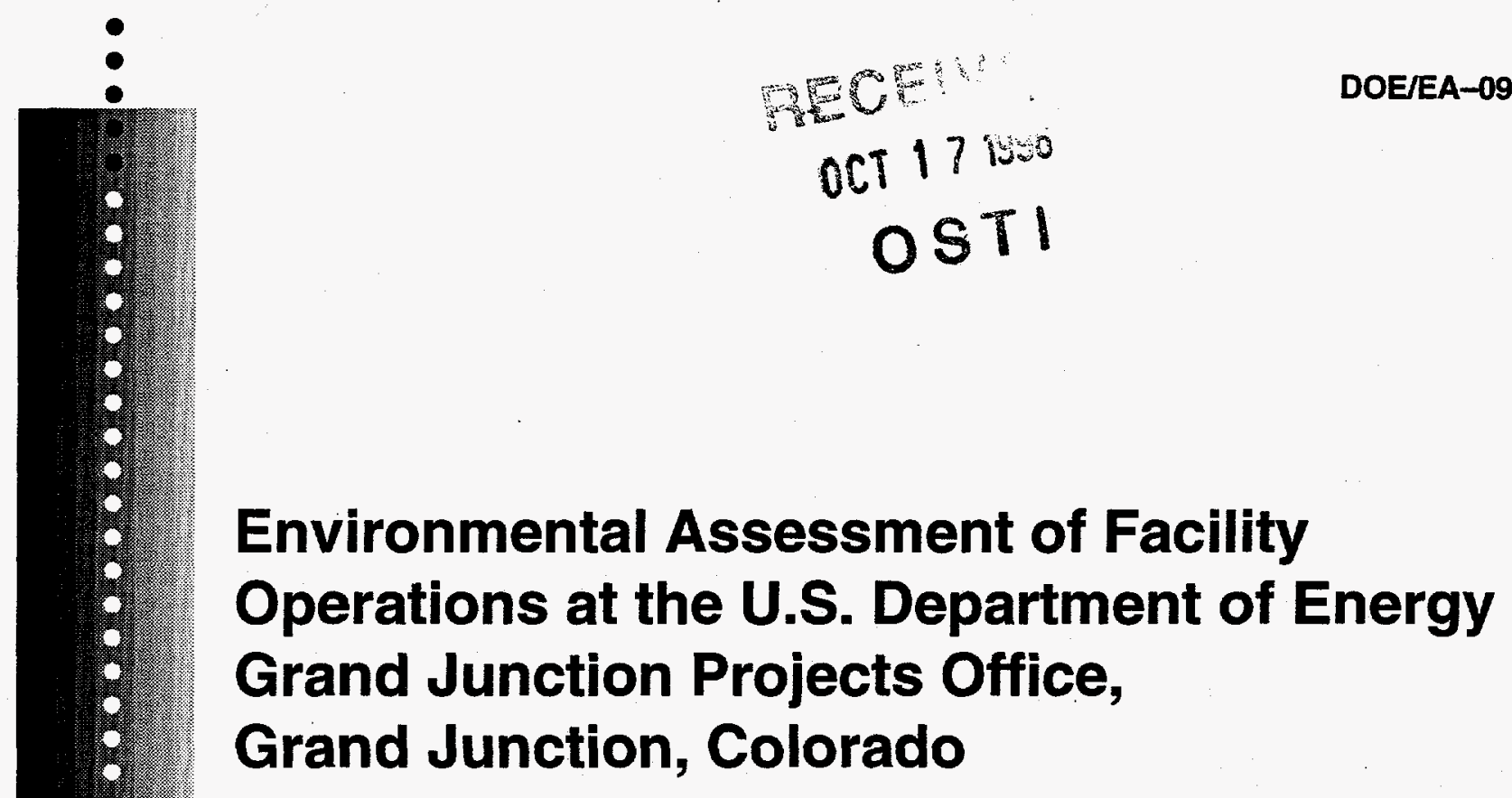

June 1996

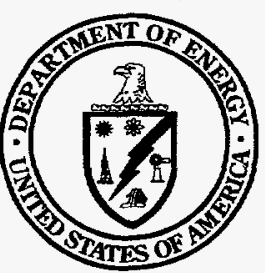

U.S. Department of Energy Grand Junction Projects Office

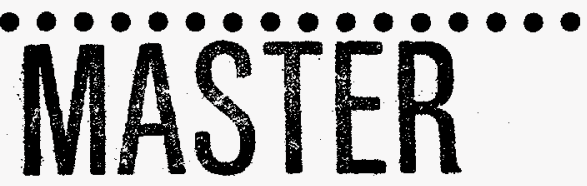




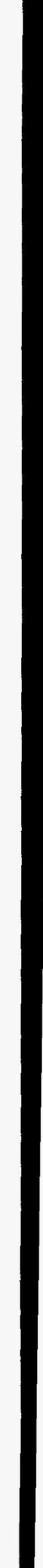




\section{U.S. DEPARTMENT OF ENERGY}

Finding of No Significant Impact, Facility Operations at the U.S. Department of Energy Grand Junction Projects Office, Grand Junction, Colorado

\section{AGENCY: U.S. Department of Energy}

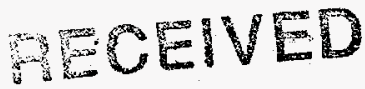

ACTION: Finding of No Significant Impact

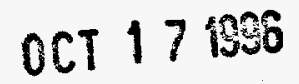

SUMMARY: The U.S. Department of Energy (DOE) has prepared a sitewide O STI environmental assessment (EA) (DOE/EA-0930) of the proposed action to continue and expand present-day activities on the DOE Grand Junction Projects Office (GJPO) facility in Grand Junction, Colorado. Because DOE-GJPO regularly proposes and conducts many different on-site activities, DOE decided to evaluate these activities in one sitewide EA rather than in multiple, activity-specific documents. On the basis of the information and analyses presented in the EA, DOE has determined that the proposed action does not constitute a major Federal action significantly affecting the quality of the human environment, as defined by the National Environmental Policy Act (NEPA) of 1969 (42 U.S. Code 4321, et seq.). Therefore, preparation of an environmental impact statement is not required for facility operations, and DOE is issuing this Finding of No Significant Impact (FONSI).

ADDRESSES: Individual copies of the EA are available from: Mr. Don Leske, Project Manager, U.S. Department of Energy Grand Junction Projects Office, P.O. Box 2567, Grand Junction, CO 81502-2567, (970) 248-6008.

FOR FURTHER INFORMATION ON THE NEPA PROCESS, CONTACT: Mr. Jeff Robbins, NEPA Compliance Officer, Environmental Protection Division, U.S. Department of Energy Albuquerque Operations Office, P.O. Box 5400, Albuquerque, NM 87115, (505) 845-4426.

\section{SUPPLEMENTARY INFORMATION:}

Background

History of GJPO Facility

GJPO facility lands were purchased in 1943 by the U.S. War Department for the development of a central refinery to treat and concentrate uranium oxide in support of the Manhattan Project. In late 1947, the U.S. Atomic Energy Commission (AEC) established an office on site to manage the domestic uranium program and to establish a uranium exploration program. AEC conducted uranium milling and assaying activities until 1971. In 1974, AEC initiated the National Uranium Resource Evaluation program to comprehensively assess the nation's uranium resources; this program was completed in 1984 by DOE, the successor agency to AEC. In recent years, DOE-GJPO has provided technical and administrative support personnel for various DOE, U.S. Department of Defense, and U.S.

DISTRIBUTION OF THIS DOCUMENT IS UMLIMITEO
$\begin{aligned} & \text { DOE/Grand Junction Projects Office } \\ & \text { June } 1996\end{aligned}$


Environmental Protection Agency (EPA) programs, including laboratory and construction services that are required to support environmental restoration activities.

\section{History of Grand Junction Projects Office Remedial Action Project}

In 1984, formal site investigations were initiated under the Grand Junction Projects Office Remedial Action Project (GJPORAP) to assess the extent of radiological contamination on the facility from past operations. Historically, uranium mill tailings and associated radioactive materials (collectively referred to as "UMT waste") were stored or disposed of on site. An estimated 76,500 cubic meters of tailings and contaminated soil was stabilized on site, and 230 cubic meters of contaminated process equipment was buried on site. Approximately one-third of the facility was assessed as contaminated.

A Remedial Investigation/Feasibility Study-EA was prepared to identify potential cleanup strategies and to satisfy NEPA and Comprehensive Environmental Response, Compensation, and Liability Act requirements (the GJPO facility, however, is not a Superfund site). A FONSI for GJPORAP removal operations was issued by DOE in 1989, and the GJPORAP Record of Decision was finalized and approved in April 1990. Removal of UMT waste began in 1989 and is ongoing. By July 1, 1994; all known exterior UMT waste had been removed from the facility and transported to the Uranium Mill Tailings Remedial Action (UMTRA) Project Cheney Disposal Cell. This cell is located 18 miles southeast of Grand Junction and is designed to permanently contain residual radioactive materials.

Future GJPORAP actions entail removal of UMT waste from facility buildings; these actions are described and analyzed in the EA associated with this FONSI.

\section{Proposed Action}

DOE proposes to continue operations at its GJPO facility, expand specific on-site facilities, and upgrade selected operations. The EA describes continuing operations under nine general categories: facility maintenance and operations, laboratory operations, GJPO tenant operations, environmental restoration activities, other GJPO operations, research and development, waste management, environmental monitoring, and workplace monitoring. In addition, the EA describes the proposed activities associated with the anticipated expansion and upgrade of GJPO facilities and operations. The need for environmental cleanup and project management support across the DOE complex would increase requirements at the GJPO for environmental restoration, waste management, research and development, engineering and geoscience capability, and laboratory capacity. Providing this increased capability would involve the renovation of existing facilities and construction of new facilities. The planned activities associated with continuation and expansion of facility operations are summarized in Table 1.

Remedial actions under GJPORAP, encompassing removal of UMT waste in on-site buildings, would continue under the proposed action. Table 2 lists the buildings proposed for decontamination and demolition. 
Table 1. Summary of Proposed Construction Activities Under the Proposed Action Alternative

\begin{tabular}{|c|c|}
\hline $\begin{array}{l}\text { Fiscal } \\
\text { Year }\end{array}$ & Proposed Construction Activity \\
\hline 1997 & $\begin{array}{l}\text { Three Modular Buildings (new buildings) } \\
\text { Radiochemistry Preparation Laboratory (upgrade within Building 20) } \\
\text { Organic Extraction Laboratory (upgrade within Building 20) } \\
\text { Health Training Facility (new building) } \\
\text { Maintenance and Testing Facility (new building) }\end{array}$ \\
\hline 1998 & $\begin{array}{l}\text { Two Modular Buildings (new buildings) } \\
\text { Emergency Operations Center (new building-replaces Building 19) } \\
\text { Environmentally Controlled Volatile Organic Measurement Laboratory (upgrade within } \\
\text { Building 20) } \\
\text { Kitchen Addition (addition to Building 46) }\end{array}$ \\
\hline 1999 & $\begin{array}{l}\text { Three Modular Buildings (new buildings) } \\
\text { New Irrigation System } \\
\text { Office Building (new building-replaces Buildings 57A-E) } \\
\text { Semivolatile Organic Laboratory (upgrade within Building 20) }\end{array}$ \\
\hline 2000 & $\begin{array}{l}\text { Northwest Office Complex (new building-replaces Buildings 2, 18, 54, and 810) } \\
\text { Medical Facility (new building) }\end{array}$ \\
\hline 2001 & Site Management Offices and Shops (new building) \\
\hline 2002 & Environmental Restoration Field Equipment Facility (new building) \\
\hline 2007 & New Analytical Chemistry Laboratory (new building) \\
\hline
\end{tabular}

\section{Environmental Impacts}

The environmental impacts associated with the proposed action are described in the EA and are summarized in this FONSI. Only those elements of the environment that would be affected by the proposed action are discussed. Because cultural resources, prime or unique farmlands, and threatened and endangered plants do not occur on or adjacent to the facility, these elements are not discussed in this FONSI. Other elements of the environment, such as land use, visual resources, floodplains, wetlands, geology, mineral resources, and recreation, may occur on or adjacent to the facility but are not affected by activities associated with the proposed action; therefore, they also are not discussed in this FONSI.

\section{Transportation}

Under the proposed action, daily traffic to and from the GJPO facility would continue as in the past. Approximately 600-660 vehicles driven by employees and approximately 50 service vehicles driven by subcontractors or delivery personnel would arrive at and depart from the facility each day. An average of three vehicle accidents per year could be expected 
Table 2. Proposed Remedial Actions Under GJPORAP

\begin{tabular}{|l|l|}
\hline \multicolumn{1}{|c|}{ Building } & \\
\hline Building 1 & Demolition \\
\hline Building 34 & Demolition \\
\hline Building 35 & Demolition \\
\hline Building 36 & Demolition \\
\hline Building 46 & Demolition of floor; tailings removal from beneath building \\
\hline Building 810 & $\begin{array}{l}\text { Assessment of contamination on soil surface; decontamination if } \\
\text { necessary }\end{array}$ \\
\hline Building 31-A & Decontamination of sump \\
\hline Building 33 & Demolition \\
\hline Building 938 & Decontamination of attic areas \\
\hline Building 2 & Decontamination or demolition \\
\hline Building 7 & Demolition \\
\hline Building 20 & Decontamination \\
\hline
\end{tabular}

to occur in the employee parking lot, and an average of two vehicle accidents per year could be expected to occur within the confines of the facility. Injuries to people are not expected to occur, and damage to vehicles is expected to be minor.

When buildings are decontaminated or demolished under GJPORAP, three to four tandem dump trucks would be used to transport waste materials to the UMTRA Cheney Disposal Cell or Mesa County landfill. Each truck would make a maximum of five trips per day and would haul a maximum of 9 cubic meters (about 17 tons) of material per trip. The impacts associated with the transportation of these wastes are discussed in the environmental impact statement for the Climax Mill Site and the Administrative Record: Grand Junction Projects Office Remedial Action Project, Direct Truck Haul of Residual Radioactive Material to the Cheney Repository.

About twice a year, approximately 500 kilograms (1,100 pounds) of hazardous, polychlorinated biphenyl (PCB), low-level, and mixed wastes would be shipped from the GJPO facility by a subcontracted waste packaging and shipping service and transported to one or more commercial waste facilities. The potential for spill accidents during transportation of these wastes would be low because of the relatively small volumes and low frequency of shipments. In addition, the potential for spills would be reduced by complying with U.S. Department of Transportation regulations for packaging and shipping and by complying with Procedure 5.5, "Shipment of Hazardous Waste, " in the DOE contractor's Stores, Property, and Transportation Desktop Manual. 
On the facility itself, a small potential for transportation accidents involving spills of hazardous, PCB, low-level, or mixed waste would exist. Wastes would be transferred periodically from satellite accumulation areas to the Waste Accumulation Modules or to the Hazardous and Mixed Waste Storage Unit. The potential for spills would be reduced by following established procedures for on-site waste transportation outlined in Procedure 7.4, "On-Site Waste Transfer," in the DOE contractor's Environmental Services Desk Instructions. Generally, no more than 150 liters (40 gallons) of waste would be transported at one time. If an accidental spill were to occur, emergency spill-response procedures in Chapter 12, "Hazardous Materials Contingency Plan and Emergency Procedures," of the GJPO Emergency Preparedness and Response Plan would be followed.

\section{Noise}

Under the proposed action, temporary increases in noise levels would result primarily from routine renovation activities, GJPORAP remedial actions, building construction, and the use of motorized vehicles. With rare exceptions, noise levels would be well below the Federal action level of 85 decibels. Administrative or engineering controls would be considered if noise levels exceeded 85 decibels, in accordance with regulations in 29 Code of Federal Regulations Section 1910.95, "Occupational Noise Exposure."

\section{Air Quality}

Radon emissions from the instrument calibration facilities and radon calibration chambers would continue to be released at a rate of approximately 0.52 curies per year. This amount would have no measurable effect on the atmospheric radon concentration at the facility boundary.

Radioparticulate emissions from the Analytical Laboratory and Baghouse and nonradiological air particulate emissions (dust) would continue to be well under applicable Federal and State standards. The expected dose to the maximally exposed off-site individual (from radioparticulate emissions) would be about 0.00006 millirem per year, which is well under the EPA and DOE dose limit of 10 millirems per year. Concentrations of nonradiological air particulate emissions also would be well under the EPA and State of Colorado maximum annual concentration of 50 micrograms per cubic meter $\left(\mu \mathrm{g} / \mathrm{m}^{3}\right)$ and maximum 24-hour concentration of $150 \mu \mathrm{g} / \mathrm{m}^{3}$. In 1993, when UMT waste was removed from exterior areas of the facility, the maximum annual concentration was $16.9 \mu \mathrm{g} / \mathrm{m}^{3}$, and the maximum 24-hour concentration was $42.8 \mu \mathrm{g} / \mathrm{m}^{3}$. Future GJPORAP operations, which would entail removal of UMT waste from buildings only, are expected to generate substantially lower concentrations of particulate matter.

\section{Soils}

Under the proposed action, areas of unknown, radiologically contaminated soils could be discovered during GJPORAP remedial actions. These soils would be removed upon discovery and hauled to the UMTRA Cheney Disposal Cell. 
Soil contamination could result if a waste or fuel spill occurred on the facility. Hazardous, PCB, low-level, or mixed wastes would be transported across the facility from satellite accumulation areas to Waste Accumulation Modules or to the Hazardous and Mixed Waste Storage Unit. However, spills would be unlikely because of the primary and secondary containment features of the packaging and waste storage areas. If a spill were to occur, the affected area would be small because of the relatively small volumes (generally less than 150 liters or $\mathbf{4 0}$ gallons) of waste transported. GJPO emergency spill-response procedures would be followed if a spill occurred. Contaminated soils would be immediately treated and/or contained so that the affected area was minimized.

Another source of potential soil contamination would be the sewer pipelines, from which sewer effluent could leak. Currently, there is no leak detection system for the pipelines. If a leak should occur, an unknown area of soil might be contaminated. If the leak were detected, contaminated soils would be treated and/or disposed of properly.

\section{Groundwater}

Under the proposed action, groundwater-quality impacts could occur as a result of a fuel or waste spill or a sewer-line leak. If a spill or leak were to occur, contaminants could migrate to the alluvial aquifer through the soil or, more likely, through the surface ponds that are in hydrologic contact with the underlying alluvial aquifer. However, it would be unlikely for the spilled contaminants to adversely affect groundwater quality because of the generally small quantities of fuel or waste transported or stored on the facility.

Because all known exterior UMT waste that historically contaminated the groundwater was removed by July 1, 1994 (contamination still exists within and under buildings), groundwater quality should improve over time by means of natural flushing. Concentrations of waterquality constituents associated with past leaching of uranium mill tailings are expected to be below applicable standards within 50 to 80 years.

\section{Surface Water}

Surface-water quality of the North Pond, South Pond, and wetlands is expected to improve over time through passive remediation of the alluvial groundwater. Surface-water impacts could occur as a result of a fuel or waste spill near or directly into a water source; however, it would be unlikely for the spilled contaminant to adversely affect water quality because of the generally small quantities of waste and fuel stored or transported on the facility. If a spill were to occur, GJPO emergency spill-response procedures would be followed.

\section{Vegetation}

Under the proposed action, impacts to vegetation could occur as a result of a fuel or waste spill. If a spill were to occur, the affected area would be minimal because of the relatively small volumes of waste and fuel stored or transported on the facility. GJPO emergency spillresponse procedures would be followed if a spill were to occur. The contaminated material 
would be immediately treated and/or contained and disposed of properly; vegetation, if destroyed or removed, would be replaced.

Minor impacts to vegetation would occur as a result of building construction. Most of the proposed construction would occur in areas currently covered with asphalt or road base. Construction of the Northwest Office Complex, the new Analytical Chemistry Laboratory, and the Medical Facility, however, would result in the removal of about 0.2 hectare ( 0.5 acre) of vegetation, consisting mainly of upland seeded species, bluegrass lawn, and ornamental trees and shrubs. This loss in vegetated area would be offset by the revegetation of disturbed ground around the newly constructed buildings.

\section{Wildlife}

Building construction and GJPORAP activities under the proposed action would cause temporary increases in noise levels, which could result in temporary displacement of wildlife. Permanent displacement of wildlife might result from the increase in human activity associated with the use of a new building, such as the Northwest Office Complex. Most of the new construction would occur in areas currently covered by asphalt or road base, which support minimal or no wildlife habitat. Construction of the Northwest Office Complex, the new Analytical Chemistry Laboratory, and the Medical Facility, however, would result in the removal of about 0.2 hectare ( 0.5 acre) of vegetation, which could result in the destruction of one to five bird nests and temporary displacement of two to three rabbits or squirrels. Destroyed habitat would be replaced by revegetating disturbed ground around the newly constructed buildings.

Potential waste or fuel spills would not substantially affect wildlife or aquatic life because (1) the spill would be contained and GJPO emergency spill-response procedures would be implemented immediately, and (2) spills into surface-water sources would be of a relatively low volume and would be diluted immediately. The greatest potential impact would be to aquatic life (e.g., frogs or frog eggs) present at the actual spill location.

\section{Socioeconomics}

Under the proposed action, continuation and expansion of GJPO facility operations would not negatively affect current socioeconomic trends in the Grand Junction area. Overall, the city and local businesses would continue to benefit from the employment of up to 680 people who buy homes, goods, and services in the area. The purchasing of local goods and services by DOE-GJPO would continue as in the past (goods and services purchased by the DOE contractor in fiscal year 1995 totaled $\$ 17.7$ million, about 70 percent of which went to local businesses). In fiscal year 2000 , the purchasing of local goods and services could decrease as a result of the completion of GJPORAP activities. 


\section{Human Health}

Workers involved in GJPORAP and waste transportation activities and personnel working in the Analytical Laboratory, Radon Laboratory, Sample Preparation Plant, Petrology Laboratory, Environmental Sciences Laboratory, Maintenance Shop, and Hazardous and Mixed Waste Storage Unit would potentially be exposed to chemicals, toxic substances, and radioactive sources. All these personnel would be required to follow established operational, health, and safety procedures to reduce or eliminate their exposure to harmful elements. Additionally, standard operating procedures would require engineering or radiological controls to be implemented to reduce exposure levels. Actual procedures that would be followed are discussed in numerous GJPO plans, manuals, and desk instructions.

Personnel involved in renovation, construction, and GJPORAP activities would have the highest exposure to tripping hazards and industrial accidents. The risk to personnel would be about the same as that for workers on any other construction site. On the GJPO facility, renovation, construction, and GJPORAP personnel would be required to attend job-site safety meetings and implement the "buddy system" to help reduce injury risks. The potential for other workers on the facility and the general public to be exposed to chemicals, toxic substances, radioactive sources, tripping hazards, or industrial accidents would be low or about the same as that for a worker in a similar office environment.

\section{Alternatives to the Proposed Action}

\section{No Action Alternative}

Under the No Action Alternative, present-day activities would continue on the GJPO facility; however, the program expansions and concomitant facility upgrades under the proposed action would not occur. Impacts associated with the continuation of GJPO operations would be very similar to those outlined for the proposed action. Slight adverse effects to humans and wildlife would occur from the continuation of current noise levels and traffic volumes on and adjacent to the facility. The potential for waste or fuel spills that could negatively affect soils, groundwater, surface water, vegetation, wildlife, or human health would continue to be negligible. If a spill were to occur, GJPO emergency spill-response procedures would be implemented immediately to mitigate the effects.

The primary impacts of the No Action Alternative would be socioeconomic. Continued operation of the GJPO facility would result in the continued employment of up to 680 people from the Grand Junction area and, subsequently, the continuation of these individuals' contributions (e.g., housing, retail sales, and community services) to the local economy. Continued operation also would sustain local procurement of a variety of materials, equipment, supplies, and subcontracted labor and services. The socioeconomic impacts of continued facility operations, which were associated with a funding of $\$ 88$ million in fiscal year 1995, would be highly beneficial. 


\section{Shutdown Alternative}

Under the Shutdown Alternative, current operations at the GJPO facility, with the exception of GJPORAP activities, would be discontinued (the GJPORAP Record of Decision commits DOE to completing GJPORAP). Programmatic responsibilities presently maintained by DOE-GJPO would be discontinued or transferred to other DOE offices. Up to 680 people would lose their jobs at the facility. Implementation of this alternative would prohibit the GJPO from supporting DOE's cleanup goals.

Termination of operations under the Shutdown Alternative would have several long-term beneficial impacts. Traffic volumes on and adjacent to the facility would be nearly eliminated, resulting in three to five fewer traffic accidents annually, less pollutant emissions, and less noise. Suspension of renovation and construction activities would result in reduced noise levels, dust concentrations, and potential for human injury. The elimination of wastes generated by and fuel used on the facility would prevent impacts to the environment from spills.

The most substantial impacts under this alternative, however, would be adverse. Socioeconomically, the loss of up to 680 jobs would negatively affect the Grand Junction housing market, local tax base, vigor of many service industries, and well-being of the community in general. The mental well-being of the terminated employees and their families also could be adversely affected for several years, until new jobs could be acquired.

FINDING: On the basis of the analysis of potential environmental impacts in the EA, the No Action and Proposed Action Alternatives to continue and expand present-day activities at the GJPO facility would not significantly affect the quality of the human environment within the meaning of NEPA. Therefore, DOE is issuing this FONSI, and an environmental impact statement is not required.

Signed in Albuquerque, New Mexico, this 8 day of Jun , 1996.

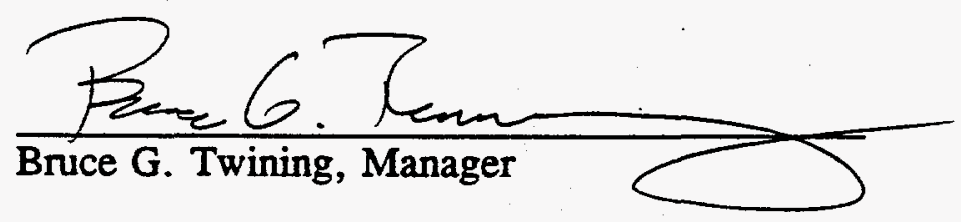





\title{
Environmental Assessment of Facility Operations at the U.S. Department of Energy Grand Junction Projects Office, Grand Junction, Colorado
}

\author{
June 1996
}

\author{
U.S. Department of Energy \\ Grand Junction Projects Office \\ 2597 B 3/4 Road \\ Grand Junction, Colorado 81503
}





\section{DISCLAIMER}

Portions of this document may be illegible in electronic image products. Images are produced from the best available original document. 


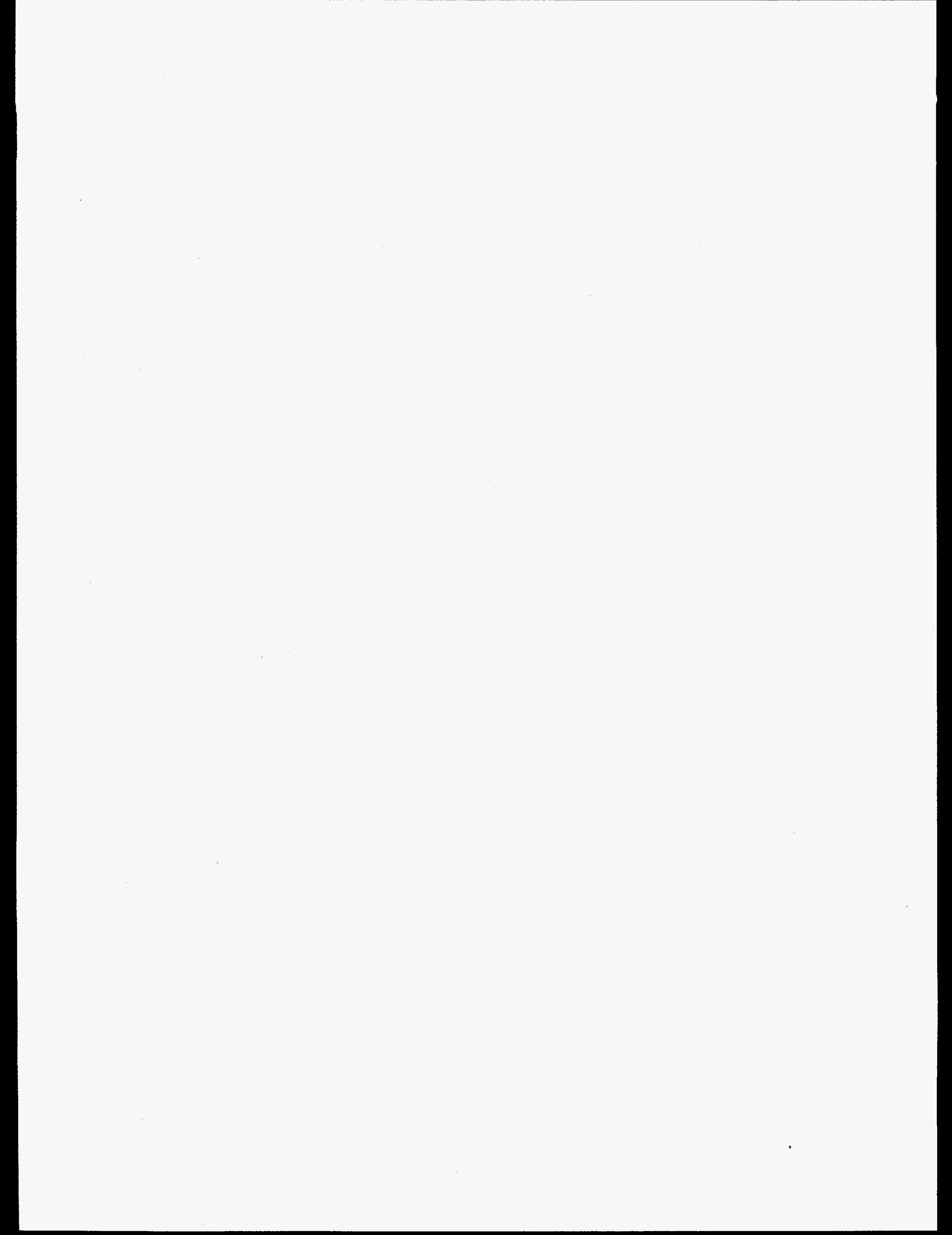




\section{Contents}

Page

Abbreviations and Acronyms $\ldots \ldots \ldots \ldots \ldots \ldots \ldots \ldots \ldots \ldots \ldots \ldots \ldots$ Definitions

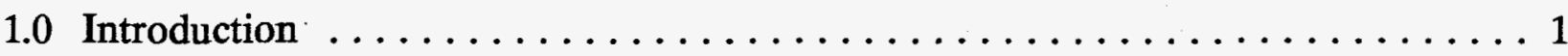

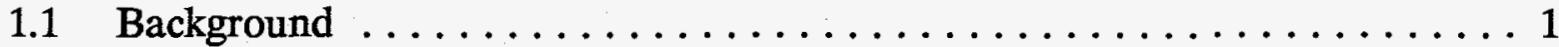

1.2 Site Description and History $\ldots \ldots \ldots \ldots \ldots \ldots \ldots \ldots \ldots \ldots \ldots \ldots \ldots$

1.3 Grand Junction Projects Office Remedial Action Project . . . . . . . . . . . 5

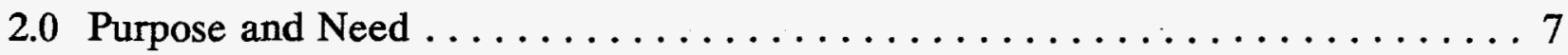

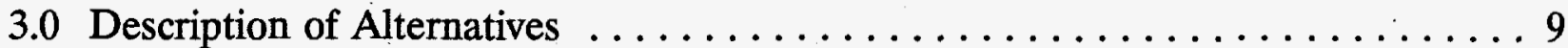

3.1 No Action Alternative $\ldots \ldots \ldots \ldots \ldots \ldots \ldots \ldots \ldots \ldots \ldots$

3.1.1 Facility Maintenance and Operations ................ 9

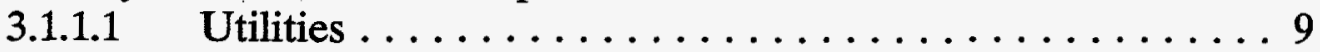

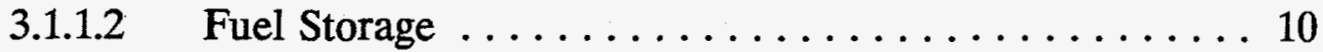

3.1.1.3 Storm-Drain System $\ldots \ldots \ldots \ldots \ldots \ldots$

3.1.1.4 Sanitary Sewer ........................ 11

3.1.1.5 Telephone Service ................. 11

3.1.1.6 Ventilation and Air Conditioning ............ 11

3.1.1.7 Energy Management ................. 11

3.1.1.8 Building Renovation . . . . . . . . . . . . . 12

3.1.1.9 Asbestos Abatement . . . . . . . . . . . . . 13

3.1.1.10 Road Renovation and Maintenance ............ 13

3.1.1.11 Facility Ground Maintenance $\ldots \ldots \ldots \ldots . \ldots \ldots$

3.1.1.12 Maintenance Shop Activities .............. 15

3.1.1.13 Site Security . . . . . . . . . . . . . . . 15

3.1.1.14 Emergency Preparedness ................. 15

3.1.1.15 Site Safety Assessment ... . . . . . . . . . . ... 16

3.1.1.16 Extremely Hazardous Substances . . . . . . . . . . 16

3.1 .2 Laboratories . . . . . . . . . . . . . . . . . . . . 16

3.1.2.1 Analytical Laboratory . . . . . . . . . . . 17

3.1.2.2 Petrology Laboratory . . . . . . . . . . . . . . . 18

3.1.2.3 Sample Preparation Plant ... . . . . . . . . . . 18

3.1.2.4 Radon Laboratory . . . . . . . . . . . . . . . . . . 19

3.1.2.5 Environmental Sciences Laboratory . . . . . . . . . . . 21

3.1.2.6 Environmental Instrumentation Laboratory . . . . . . . . 22

3.1 .3 GJPO Tenant Operations ..................... 23

3.1.3.1 Oak Ridge National Laboratory Operations . . . . . . . . . 23

3.1.3.2 Los Alamos Core and Sample Repository . . . . . . . . 23

3.1.3.3 General Services Administration ... . . . . . . . . 24

3.1.3.4 U.S. Army Reserve ... . . . . . . . . . . . . . . 24

3.1.4 Environmental Restoration Activities . . . . . . . . . . . . . . . 24 


\section{Contents (continued)}

Page

3.1.5 Other GJPO Operations $\ldots \ldots \ldots \ldots \ldots \ldots \ldots \ldots \ldots \ldots 26$

3.1.5.1 On-Site Medical Facility . . . . . . . . . . . 26

3.1.5.2 Instrument Calibration Facilities $\ldots \ldots \ldots \ldots \ldots \ldots 26$

3.1.5.3 Copying Services . . . . . . . . . . . . . . 27

3.1.5.4 On-Site Food Service ................ 27

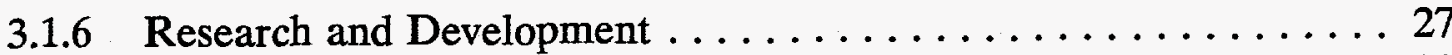

3.1.7 Waste Management.......................... 29

3.1.7.1 Waste Types ..................... 30

3.1.7.2 Waste Minimization ................. 32

3.1.7.3 Waste Accumulation and Storage ........... 32

3.1.7.4 Waste Transportation and Disposal ........... 33

3.1.7.5 Mixed-Waste Treatment Program ............. 34

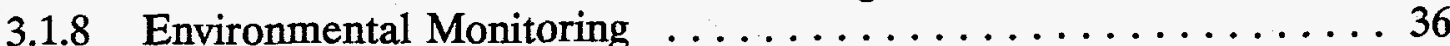

3.1.8.1 Groundwater ....................... 36

3.1.8.2 Surface Water . . . . . . . . . . . . . . . 36

3.1.8.3 Wetland Areas $\ldots \ldots \ldots \ldots \ldots \ldots \ldots \ldots \ldots \ldots \ldots$

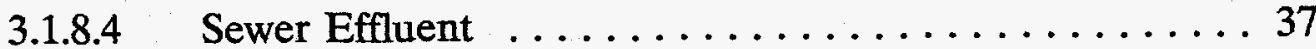

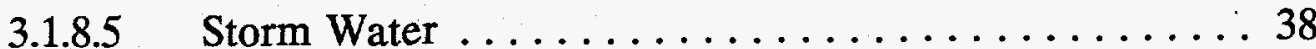

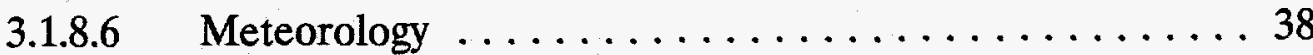

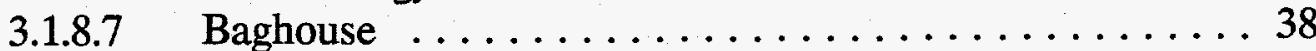

3.1.9 Workplace Monitoring $\ldots \ldots \ldots \ldots \ldots \ldots \ldots \ldots \ldots \ldots \ldots$

3.1.9.1 Radiation Exposure Surveys . . . . . . . . . . 39

3.1.9.2 Contamination Surveys $\ldots \ldots \ldots \ldots \ldots \ldots \ldots \ldots . \ldots \ldots$

3.1.9.3 Airborne Radioactivity Monitoring ........... 40

3.2 Proposed Action Alternative $\ldots \ldots \ldots \ldots \ldots \ldots \ldots \ldots \ldots \ldots . \ldots . \ldots$

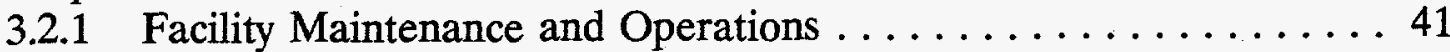

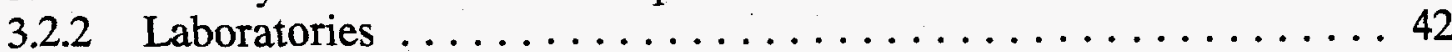

3.2.3 Environmental Restoration Activities ............... 45

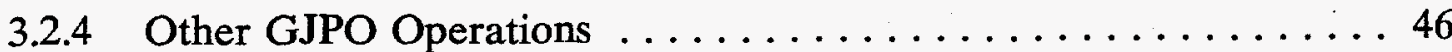

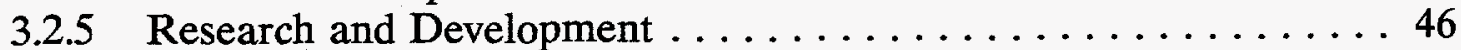

3.2.6 Waste Management ....................... 48

3.3 Shutdown Alternative $\ldots \ldots \ldots \ldots \ldots \ldots \ldots \ldots \ldots \ldots \ldots$

4.0 Affected Environment $\ldots \ldots \ldots \ldots \ldots \ldots \ldots \ldots \ldots \ldots \ldots \ldots \ldots \ldots$

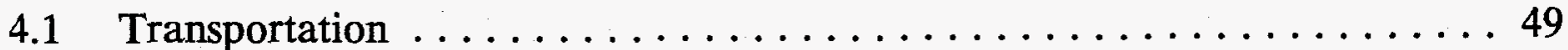

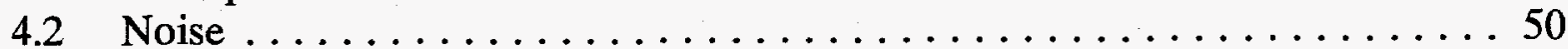

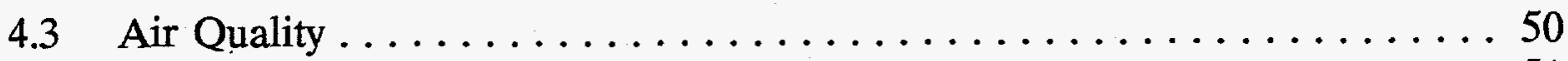

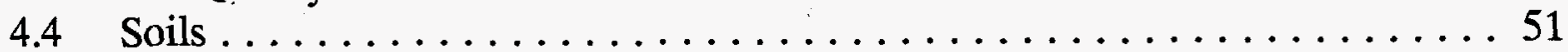

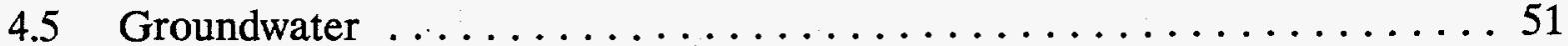

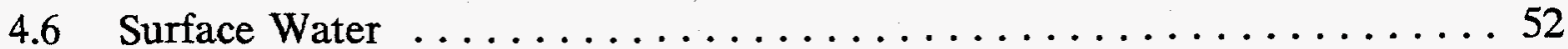

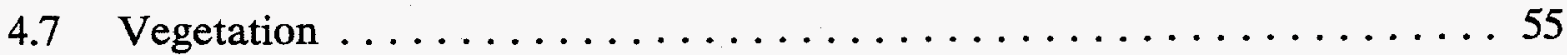

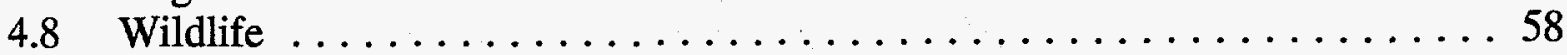




\section{Contents (continued)}

Page

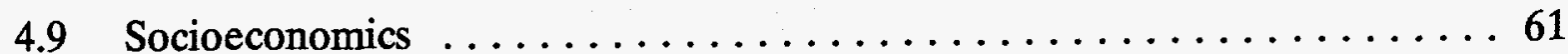

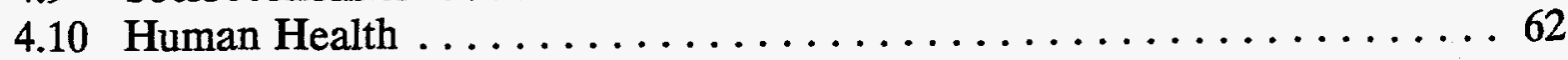

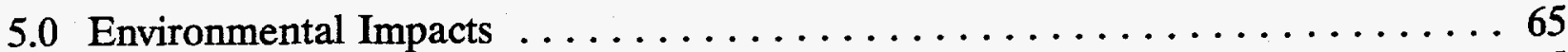

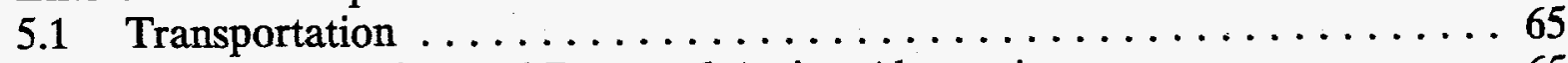

5.1 .1 No Action and Proposed Action Alternatives ........... 65

5.1.2 Shutdown Alternative . . . . . . . . . . . . . . . . 67

$5.2 \quad$ Noise . . . . . . . . . . . . . . . . . . . . . . 68

5.2.1 No Action and Proposed Action Alternatives ........... 68

5.2.2 Shutdown Alternative $\ldots \ldots \ldots \ldots \ldots \ldots \ldots \ldots \ldots 6$

5.3 Air Quality . . . . . . . . . . . . . . . . . . . 68

5.3.1 No Action and Proposed Action Alternatives . . . . . . . . 68

5.3.2 Shutdown Alternative $\ldots \ldots \ldots \ldots \ldots \ldots \ldots \ldots \ldots \ldots$

5.4 Soils . . . . . . . . . . . . . . . . . . . . . . . . 69

5.4.1 No Action and Proposed Action Alternatives ............ 69

5.4 .2 Shutdown Alternative $\ldots \ldots \ldots \ldots \ldots \ldots \ldots \ldots \ldots 69 \ldots \ldots$

5.5 Groundwater .............................. 69

5.5.1 No Action and Proposed Action Alternatives ............ 69

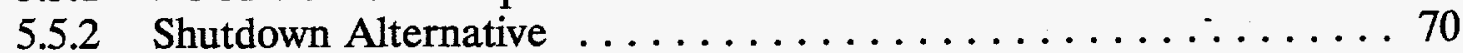

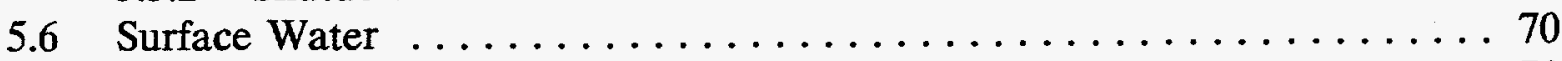

5.6.1 No Action and Proposed Action Alternatives ........... 70

5.6 .2 Shutdown Alternative $\ldots \ldots \ldots \ldots \ldots \ldots \ldots \ldots \ldots \ldots$

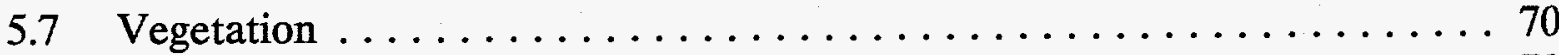

$5.7 .1 \quad$ No Action Alternative $\ldots \ldots \ldots \ldots \ldots \ldots \ldots \ldots \ldots \ldots \ldots \ldots \ldots \ldots \ldots$

5.7.2 Proposed Action Alternative $\ldots \ldots \ldots \ldots \ldots \ldots \ldots \ldots \ldots \ldots \ldots \ldots \ldots$

5.7 .3 Shutdown Alternative $\ldots \ldots \ldots \ldots \ldots \ldots \ldots \ldots \ldots \ldots \ldots \ldots \ldots$

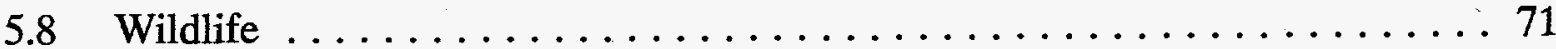

5.8 .1 No Action Alternative $\ldots \ldots \ldots \ldots \ldots \ldots \ldots \ldots \ldots \ldots \ldots \ldots \ldots \ldots$

5.8.2 Proposed Action Alternative $\ldots \ldots \ldots \ldots \ldots \ldots \ldots \ldots \ldots . \ldots \ldots$

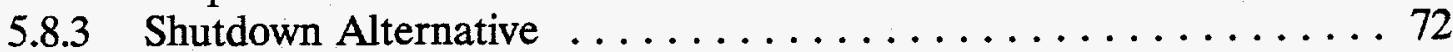

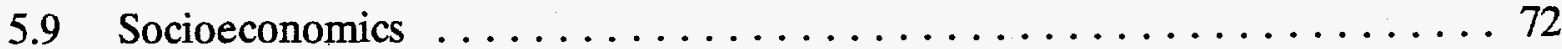

5.9.1 No Action and Proposed Action Alternatives ........... 72

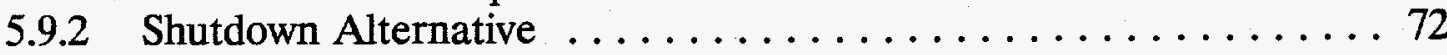

5.10 Human Health . . . . . . . . . . . . . . . . . . . 72

5.10 .1 No Action and Proposed Action Alternatives ........... 72

5.10 .2 Shutdown Alternative $\ldots \ldots \ldots \ldots \ldots \ldots \ldots \ldots \ldots \ldots \ldots$

5.11 Environmental Justice Considerations $\ldots \ldots \ldots \ldots \ldots \ldots \ldots \ldots \ldots \ldots$

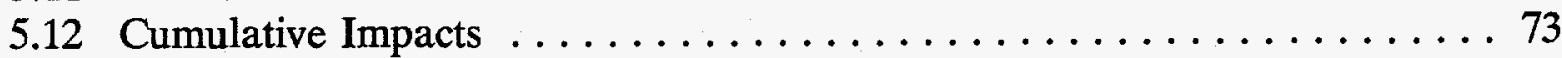

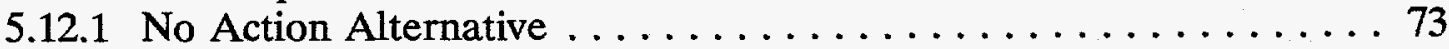

5.12 .2 Proposed Action Alternative $\ldots \ldots \ldots \ldots \ldots \ldots \ldots \ldots \ldots \ldots \ldots$

5.12 .3 Shutdown Alternative $\ldots \ldots \ldots \ldots \ldots \ldots \ldots \ldots \ldots \ldots$ 


\section{Contents (continued)}

Page

5.13 Accident Analysis . . . . . . . . . . . . . . . . . 75

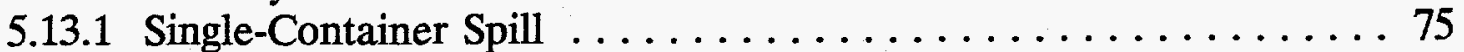

5.13.2 Fire or Explosion in the Hazardous and Mixed Waste

Storage Unit . . . . . . . . . . . . . . . . 76

5.13.3 Worst-Case Accident, Earthquake . .............. 77

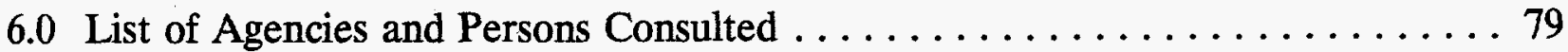

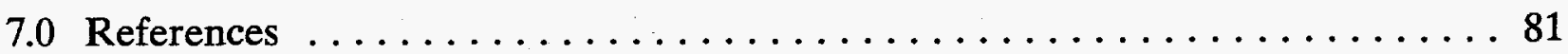

\section{Figures}

Figure 1. GJPO Site Location Map ...................... 2

2. General Layout of GJPO Facility . ................ 3

3. Proposed Renovation and Construction on GJPO Facility ....... 43

\section{Tables}

Table 1. Chemical Products Used at the GJPO Facility for Ground Maintenance . 14

2. Summary of Radon Emissions From Sources Used in the

Radon Laboratory ....................... 20

3. Summary of GJPO Research and Development Projects for FY 1994 and FY $1995 \ldots \ldots \ldots \ldots \ldots \ldots \ldots \ldots \ldots \ldots \ldots \ldots$

4. Summary of Planned Construction Activities Under the Proposed Action Alternative ...................... 41

5. Proposed Remedial Actions under GJPORAP ............. 45

6. Summary of GJPO Research and Development Projects for FY 1996 . . 47

7. Comparison of Federal and State of Colorado Groundwater Quality Standards to 1994 and Historical Maximum Concentrations in the Alluvial Aquifer . . ........................53

8. Comparison of State of Colorado Surface-Water Quality Standards to 1994 and Historical Maximum Concentrations in the Gunnison River . 56

9. Plant Species Observed On or Near the GJPO Facility .......... 57

10. Wildlife Observed or Likely To Occur in the Vicinity of the GJPO Facility . . . . . . . . . . . . . . . . . . . . . . . 59

11. Radiation Doses to Aquatic Organisms . ...............6 61

12. Summary Table of Environmental Impacts $\ldots \ldots \ldots \ldots \ldots \ldots 66$ 


\section{Abbreviations and Acronyms}

$\begin{array}{ll}\text { CDPHE } & \text { Colorado Department of Public Health and Environment } \\ \text { CESQG } & \text { conditionally exempt small quantity generator } \\ \text { CFR } & \text { Code of Federal Regulations } \\ \text { Ci/yr } & \text { curies per year } \\ \text { COE } & \text { U.S. Army Corps of Engineers } \\ \text { DOE } & \text { U.S. Department of Energy } \\ \text { EA } & \text { environmental assessment } \\ \text { EPA } & \text { U.S. Environmental Protection Agency } \\ \text { EPI } & \text { Emergency Prediction Information } \\ \text { FY } & \text { fiscal year } \\ \text { g } & \text { ground motion expressed in terms of gravitational acceleration } \\ \text { GJPO } & \text { Grand Junction Projects Office } \\ \text { GJPORAP Grand Junction Projects Office Remedial Action Project } \\ \text { HEPA } & \text { high-efficiency particulate air (filter) } \\ \text { IDLH } & \text { immediately dangerous to life and health } \\ \text { LTSM } & \text { long-term surveillance and maintenance } \\ \text { } \text { g/m } & \text { micrograms per cubic meter } \\ \text { mg/L } & \text { milligrams per liter } \\ \text { mrem/yr } & \text { millirems per year } \\ \text { NEPA } & \text { National Environmental Policy Act } \\ \text { NPDES } & \text { National Pollutant Discharge and Elimination System } \\ \text { ORNL } & \text { Oak Ridge National Laboratory } \\ \text { PCBs } & \text { polychlorinated biphenyls } \\ \text { pCi/L } & \text { picocuries per liter } \\ \text { PM } 10 & \text { particulate matter less than 10 micrometers in diameter } \\ \text { ppm } & \text { parts per million } \\ \text { RCRA } & \text { Resource Conservation and Recovery Act } \\ \text { RI/FS } & \text { Remedial Investigation/Feasibility Study } \\ \text { RMMA } & \text { radioactive materials management area } \\ \text { SARA } & \text { Superfund Amendments and Reauthorization Act } \\ \text { SQG } & \text { small quantity generator } \\ \text { STEL } & \text { short-term exposure limit } \\ \text { TSCA } & \text { Toxic Substances Control Act } \\ \text { TWA } & \text { time-weighted average } \\ \text { UMTRA } & \text { Uranium Mill Tailings Remedial Action } \\ \text { UMT } & \text { uranium mill tailings } \\ \text { WM/PEIS } & \text { Draft Waste Management Programmatic Environmental Impact Statement } \\ & \\ & \end{array}$ 
page left

intentionally blank 


\section{Definitions}

Curie: A unit of activity of a radionuclide. A curie is equal to $3.7 \times 10^{10}$ disintegrations (i.e., nuclear transformations) per second.

Decommissioning: Actions taken to reduce the potential health and safety impacts of DOE contaminated facilities, including activities to stabilize, reduce, or remove radioactive materials or to demolish the facilities.

Decontamination: The removal of radioactive contamination from facilities, equipment, or soils by washing, heating, chemical or electrochemical action, mechanical cleaning, or other techniques.

Hazardous waste: Those wastes that are designated hazardous by 40 CFR Part 261 . In Colorado, hazardous wastes also are defined by the Colorado Hazardous Waste Regulations at 6 Colorado Code of Regulations Section 1007-3.

High-level waste: The highly radioactive waste material that results from the reprocessing of spent nuclear fuel, including liquid waste produced directly in reprocessing and any solid waste derived from the liquid, that contains a combination of transuranic waste and fission products in concentrations requiring permanent isolation.

Low-level waste: Waste that contains radioactivity and is not classified as high-level waste, transuranic waste, spent nuclear fuel, or uranium mill tailings (UMT) waste.

Mixed waste: Waste containing both radioactive and hazardous components as defined by the Resource Conservation and Recovery Act, as amended by the Federal Facilities Compliance Act.

Nonregulated waste: Waste that is not subject to stringent storage, treatment, or disposal requirements and that can be disposed of in a municipal landfill.

Rad: A unit of absorbed dose for any ionizing radiation. A rad is equal to 100 ergs absorbed per gram of any substance or 0.01 joule per kilogram. For water and soft tissues, the absorbed dose per roentgen is between 0.93 and $0.98 \mathrm{rad}$. Therefore, the roentgen and rad are nearly equivalent numerically.

Radiological contamination: Contamination of property, material, or equipment by radionuclides at levels above those specified in DOE Order 5400.5, Radiation Protection of the Public and the Environment, Table IV-1.

Regulated waste: Waste that is deemed to be hazardous, radioactive, mixed, or toxic under the Resource Conservation and Recovery Act, Atomic Energy Act as amended by the Uranium Mill Tailings Radiation Control Act, and Toxic Substances Control Act. These wastes are subject to stringent storage, treatment, and disposal requirements. 
Residual radioactive material: Waste in the form of tailings resulting from the processing of ores and other waste related to such processing; these wastes are regulated under the Uranium Mill Tailings Radiation Control Act.

Roentgen: A special unit of exposure for $\mathrm{x}$ - or gamma radiation that describes the quantity of ionization that these radiations produce in the air.

Spent nuclear fuel: Fuel that has been withdrawn from a nuclear reactor following irradiation, but that has not been reprocessed to remove its constituent elements.

Transuranic waste: Without regard to source or form, waste that is contaminated with alpha-emitting transuranium radionuclides with half-lives greater than 20 years and concentrations greater than 100 nanocuries per gram at the time of assay.

UMT waste: Uranium mill tailings and associated wastes derived from the processing of ores and related activity and controlled by the Grand Junction Projects Office Remedial Action Project. UMT wastes are defined as such to maintain a distinction with residual radioactive material, which is defined under the Uranium Mill Tailings Radiation Control Act. 


\subsection{Introduction}

\subsection{Background}

The U.S. Department of Energy (DOE) Grand Junction Projects Office (GJPO) has prepared this environmental assessment (EA) to provide the public with information on the potential impacts associated with operations at its facility in Grand Junction, Colorado. DOE is required to assess the potential consequences of its activities on the human environment under the regulations of the National Environmental Policy Act (NEPA) (42 U.S. Code Sections 4321-4370B). Because DOE-GJPO regularly proposes and conducts many different on-site activities, DOE decided that these activities would be evaluated in one NEPA document rather than in multiple NEPA documents. Preparation of one document saves time and money and allows DOE-GJPO to address cumulative impacts from facility operations.

If the impacts associated with facility operations are identified as insignificant as a result of this EA, DOE shall issue a Finding of No Significant Impact and will authorize future on-site operations at the GJPO facility. If impacts are identified as significant and adverse, an Environmental Impact Statement will be prepared.

This EA was prepared in compliance with Recommendations for the Preparation of Environmental Assessments and Environmental Impact Statements (DOE 1993c).

Chapter 1.0 of this EA provides a site description of the GJPO facility and a brief history of facility operations, Chapter 2.0 discusses the purpose of present-day operations, Chapter 3.0 presents the three alternative actions assessed in this EA, Chapter 4.0 describes the existing environment at the facility that may be affected by the alternative actions, and Chapter 5.0 describes potential impacts to that environment.

\subsection{Site Description and History}

The GJPO facility is about 3 kilometers ( 2 miles) south of the main business district of the city of Grand Junction at an elevation of 1,390 meters (4,570 feet) above sea level (Figure 1). Situated on a bend of the Gunnison River, the facility occupies 25 hectares (61.7 acres) of federally owned land bounded on the north, south, and west by the Gunnison River. Bordering the east side of the facility is a 0.5 -hectare (1.3-acre) tract of land leased from the Southern Pacific Railroad for GJPO employee parking. Adjacent to the parking area is the Southern Pacific Railroad and a city-owned cemetery. The 44 buildings and structures within the facility's boundaries are used for employee offices, laboratories, maintenance shops, or storage (Figure 2).

The GJPO facility lands were acquired by the U.S. War Department in August 1943 to support the Manhattan Project. Under contract with the Federal Government, the U.S. 


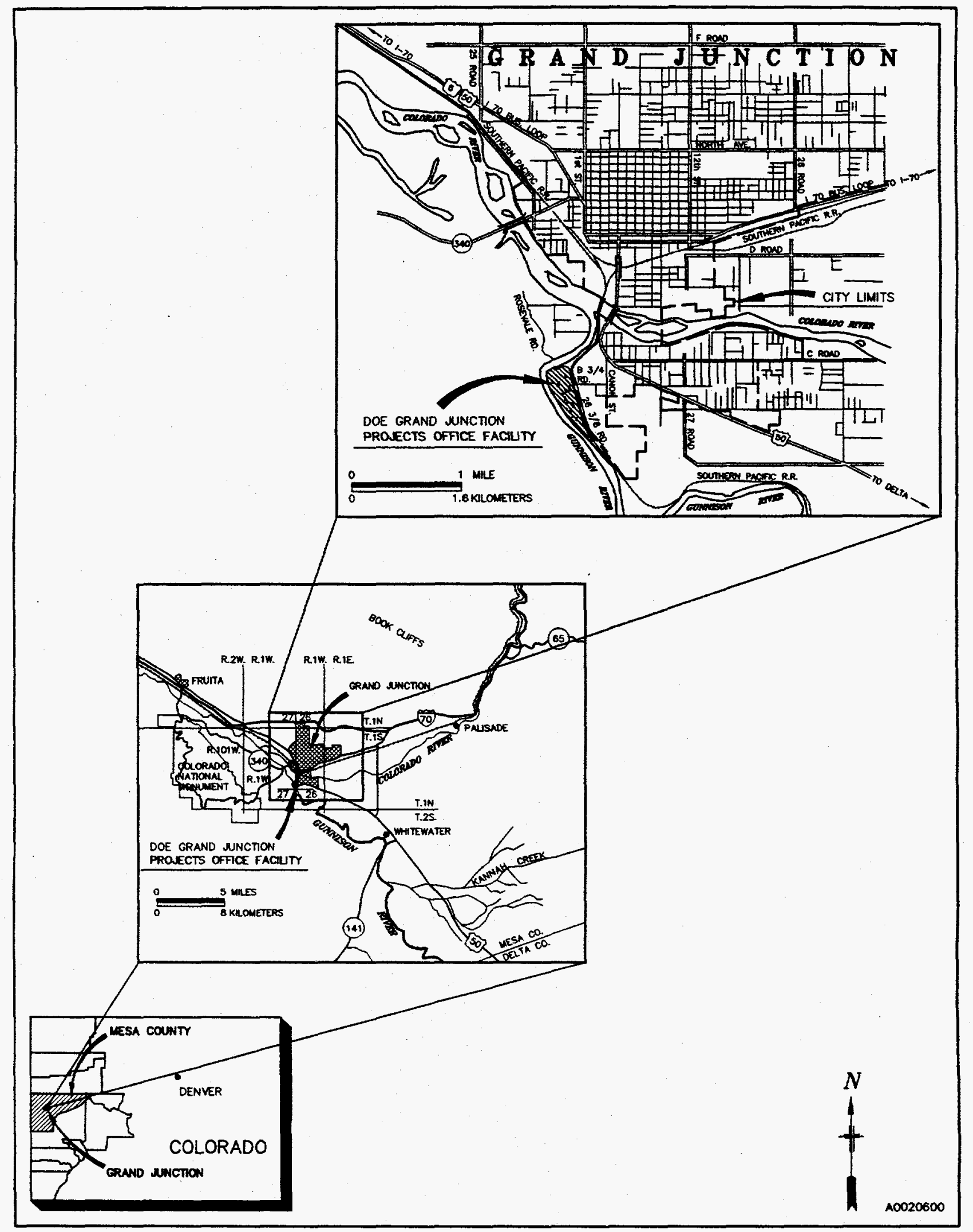

Figure 1. GJPO Site Location Map 


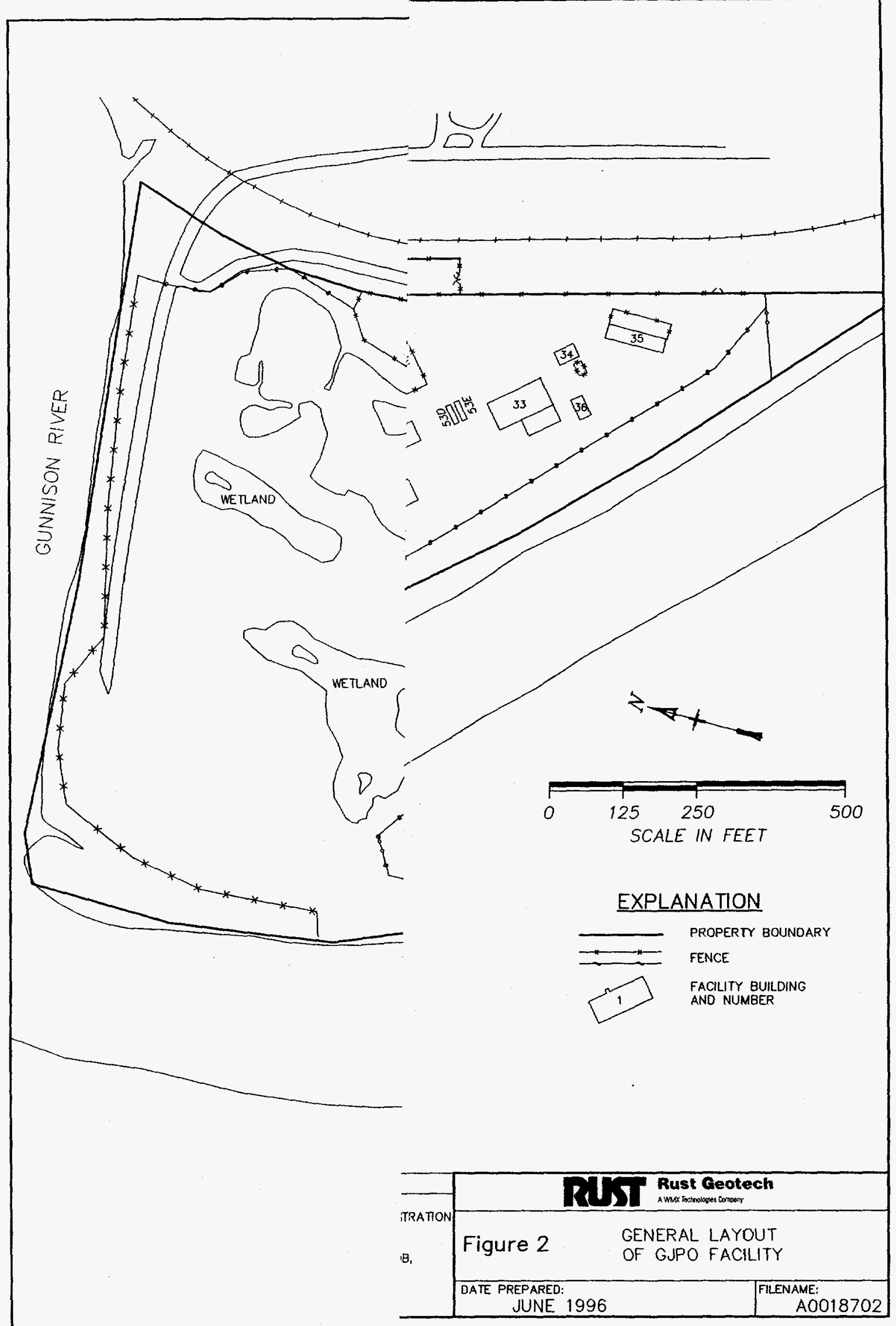


page left

intentionally blank 
Vanadium Corporation constructed and operated a refinery from 1943 to 1947 in which green sludges of uranium oxide were roasted and concentrated. Produced in the refining process were a 20-percent uranium oxide sludge and a vanadium concentrate ("fused black flake"). Wastes from the refinery consisted of dust, several hundred tons of alumina cake, and liquid discharges.

In December 1947, the U.S. Atomic Energy Commission established the Colorado Raw Materials Office at the GJPO facility to manage the domestic uranium procurement program and establish a uranium exploration program. Personnel at the office were responsible for the receipt, sampling, and analysis of uranium and vanadium concentrates purchased from ore-processing operations in the western United States. Between 1948 and 1971 , a total of 157,500 metric tons $(173,650$ tons) of uranium oxide and 12,970 metric tons $(14,300$ tons) of vanadium oxide were received and stockpiled in steel drums at the facility. The last shipments of vanadium and uranium to the facility occurred in 1965 and 1975, respectively.

A pilot-plant program was initiated in 1953 with the construction of a small plant that was used for research into the development of a resin-in-pulp milling process. After 1954, the pilot-plant program was dedicated to amenability testing of uranium ores and to the development and testing of new uranium milling processes. A new, larger pilot plant, consisting of two mill buildings, a crushing and sampling plant, office, laboratory, warehouse, and maintenance shop, was constructed in the south portion of the GJPO facility. From 1954 until it was closed in 1958, the pilot plant operated three circuits on a 24-hour-a-day, 7-day-a-week basis. Uranium mill tailings from this plant, at first, were allowed to pond just west of what are now Buildings 31A and 33 (Figure 2). A slurry line was later constructed to carry the tailings to a gravel pit located at the present-day site of the South Pond.

After the closure of the pilot plant in 1958, the GJPO facility was used as a regional office for a variety of DOE programs directed toward uranium procurement, domestic uranium resource evaluation, and the advancement of geological and geophysical techniques. In recent years, the GJPO has provided technical and administrative support personnel for various DOE, U.S. Department of Defense, and U.S. Environmental Protection Agency (EPA) programs, including laboratory and construction services that are required to support environmental restoration activities.

\subsection{Grand Junction Projects Office Remedial Action Project}

In 1984, site characterization and remedial action studies were initiated to assess the extent of radiological contamination on the facility from early GJPO operations. The studies and subsequent cleanup were conducted under the Grand Junction Projects Office Remedial Action Project (GJPORAP). Under GJPORAP, a Remedial Investigation/Feasibility Study (RI/FS) -EA (DOE 1989) was prepared to determine cleanup strategies and to satisfy requirements of NEPA and the Comprehensive Environmental Response, Compensation, and Liability Act of 1980 (42 U.S. Code 
Sections 9601-9675) (the GJPO facility, however, is not a Superfund site). A Finding of No Significant Impact for GJPORAP removal operations was made by DOE in 1989, and the GJPORAP Record of Decision (DOE 1990a) was finalized and approved by the DOE Idaho Operations Office in April 1990.

Removal of uranium mill tailings and associated radioactive materials (hereinafter referred to as UMT waste [see Definitions section]) began in 1989 and continues today. By July 1, 1994, all known exterior (i.e., open-land-area) UMT waste had been removed from the facility and transported to the Uranium Mill Tailings Remedial Action Project (UMTRA) Cheney Disposal Cell (DOE 1995b). This cell is located 18 miles southeast of Grand Junction and is designed to permanently contain residual radioactive materials. A description and analysis of the cell is in the Final Environmental Impact Statement, Remedial Actions at the Former Climax Uranium Company Uranium Mill Site, Grand Junction, Mesa County, Colorado (DOE 1986).

Initially, the GJPORAP work scope emphasized identifying, removing, and disposing UMT waste located in open-land areas of the facility. Few buildings were believed to be contaminated; those that contained contamination were decontaminated to the extent practicable or demolished. In 1993, however, an extensive surface-contamination survey was conducted, and contamination was identified in additional buildings. These buildings were added to the GJPORAP work scope in 1994, the year remediation of open-land areas was completed. Comprehensive release surveys also were added to the work scope. Although building demolition was not specifically described in the GJPORAP RI/FS-EA, DOE-GJPO considered it to be within the scope of impacts described in the RI/FS-EA (Administrative Record dated August 15, 1994 [DOE 1994c]). DOE began remediating the additional contaminated buildings in 1994, and performed several partial and complete remediations in 1995. Some release surveys also were performed. GJPORAP actions beginning in 1996 are described and analyzed in this EA (see Sections 3.2.3 and 5.0). 


\subsection{Purpose and Need}

The purpose of operations at the GJPO facility is to support the environmental program goals of DOE, which originated from the need to protect human health and the environment. DOE decided that the GJPO would continue to play a significant role in supporting DOE's environmental activities, which encompass environmental restoration (including soil and groundwater), decontamination and decommissioning (see Definitions section), research and development, waste management and analysis, and environmental monitoring. 
page left

intentionally blank 


\subsection{Description of Alternatives}

Three potential alternatives are associated with operations at the GJPO facility: the No Action Alternative, Proposed Action Alternative, and Shutdown Alternative. The No Action Alternative represents the "status quo" or continuation of present-day activities on the facility and serves as the baseline against which the other alternatives are compared. The Proposed Action Alternative proposes an expansion and upgrade of on-site facilities and operations. This expansion and upgrade enhances the facility's ability to support DOE's goals. The Shutdown Alternative addresses the termination of operations at the GJPO facility. This latter alternative, which is required to be addressed in this EA, would prohibit the GJPO facility from supporting DOE's cleanup goals. If a shutdown of the GJPO facility would actually occur in the future, an additional EA would be prepared to assess the possible actions that could occur under a shutdown scenario. The following sections describe the activities and operations that would occur at the GJPO facility under each of the alternatives.

\subsection{No Action Alternative}

Under the No Action Alternative, the activities and operations that would continue to occur are addressed under nine general categories: facility maintenance and operations, laboratories, GJPO tenant operations, environmental restoration activities, other GJPO operations, research and development, waste management, environmental monitoring, and workplace monitoring. These operations and activities are described in the following sections. DOE would continue to operate the GJPO facility in compliance with environmental requirements of DOE, other Federal agencies, State of Colorado, Mesa County, and city of Grand Junction.

\subsubsection{Facility Maintenance and Operations}

\subsubsection{Utilities}

Electrical Power: Electrical power is supplied to the facility by the Public Service Company of Colorado through a 13,000-volt main feeder to the main substation south of Building 810. DOE-GJPO owns the primary and secondary electrical systems on the facility. Average monthly on-peak and off-peak electrical usages for the GJPO are 929 and 787 kilowatts, respectively.

Forty electrical transformers are located on the facility. In 1988, all on-site electrical transformers with regulated concentrations (greater than or equal to 50 parts per million [ppm]) of polychlorinated biphenyls (PCBs) were retrofilled with dielectric fluid to contain less than $50 \mathrm{ppm}$ PCBs and were recertified as containing less than $50 \mathrm{ppm}$. An off-site contractor disposed of the removed dielectric fluid at a permitted EPA treatment facility. 
Natural Gas: The Public Service Company of Colorado and the Western Natural Gas and Transmission Corporation supply natural gas to the facility through a feed line located in Building 40. From Building 40, natural gas is piped to Building 1 and then distributed through polyethylene lines to all the gas-fired hot-water boilers on the facility. Heat is generated in these cast-iron sectional hot water boilers and distributed to individual rooms. Exhaust gases produced by the heating system include negligible amounts of carbon monoxide and nitrous oxide:

Water Supply: The GJPO contracts with the city of Grand Junction for domestic water. The city generally obtains water from Kannah Creek and rarely draws water from the Colorado and Gunnison Rivers. Domestic water is used for most operations on the facility-drinking, laboratory purposes, fire protection, and lawn irrigation. Occasionally, water is pumped from the Gunnison River and used to irrigate newly reclaimed areas. In 1989, drinking water from all water coolers on site was tested for lead. The analytical results indicated that the drinking water was in compliance with the Colorado drinking water standard for inorganic lead $(0.005$ milligram per liter $[\mathrm{mg} / \mathrm{L}])$.

\subsubsection{Fuel Storage}

Fuel is stored in three areas on the GJPO facility. A small quantity (approximately 10 gallons) of unleaded gasoline for use in the maintenance shops is stored in approved 2.5- and 5-gallon gasoline containers inside Building 28 in a flammable materials storage area. About 10 gallons of diesel fuel is stored in a metal fuel tank in Building 1 for use in operating an emergency generator in the event of a power outage. The third source is a 500-gallon propane tank located south of Building 20. Propane fuel is piped into Building 20 and is used to operate fusion furnaces in the Analytical Laboratory. Protection of the tank is ensured by the placement of six steel posts around the tank.

\subsubsection{Storm-Drain System}

A series of drain lines underlie the GJPO facility and collect storm-water runoff. During precipitation events, storm water is routed through the buried lines into a lift station near the southern terminus of the South Pond. It is discharged into the South Pond once the water level within the lift station reaches the elevation of the discharge line. Because the storm-water effluent consists of runoff from the facility parking lots, office buildings, and paved areas, EPA determined in 1992 (Burm 1992) that a National Pollutant Discharge Elimination System (NPDES) permit was not required for the facility. Current site activities and operations are continually evaluated for applicability to NPDES regulations. To date, no activities that would require DOE to obtain an NPDES storm-water permit have been identified. 


\subsubsection{Sanitary Sewer}

Sewer effluent from the GJPO facility is routed to the publicly owned treatment works operated by the city of Grand Junction. The effluent consists of domestic sewage; typical industrial discharges from the Analytical Chemistry, Radon, and Environmental Sciences Laboratories; detergent wash water from the cafeteria; and water used by maintenance personnel to clean paint brushes.

In March 1989, the city issued an Industrial Pretreatment Permit (No. 0023) to the GJPO in accordance with provisions in Article 10 of Chapter 25, Code of Ordinance for the city of Grand Junction. Article 10 sets forth uniform requirements for users of city and county publicly owned treatment works and enables the city to comply with the Clean Water Act of 1977, the General Pretreatment Regulations (40 CFR Part 403), and the Colorado Water Quality Control Act, all as amended. The permit was revised by the city in February 1993. The revision requires that the sewer effluent be sampled for biological oxygen demand, oil and grease, PCBs, $\mathrm{pH}$, silver, total suspended solids, total dissolved solids, ammonia, and temperature. The revised permit establishes threshold limits for temperature, $\mathrm{pH}$, oil and grease, $\mathrm{PCBs}$, and silver. As required by the permit, DOE-GJPO samples its sewer effluent quarterly and reports the results to the city by January 31, April 30, July 31, and October 31 each year.

\subsubsection{Telephone Service}

Telecommunications specialists install, program, and maintain telephones and telephone lines at the GJPO facility. The U S West central office in Grand Junction, Colorado, provides phone service for off-site local calls; the Federal Telephone System furnishes long-distance phone service.

\subsubsection{Ventilation and Air Conditioning}

Room air conditioners, evaporative coolers, central air conditioning units, and cooling towers supply ventilation and air conditioning to facility buildings. All evaporative units that contained asbestos have been replaced.

Qualified on-site personnel and off-site subcontractors perform repair and Freon recharging of the refrigeration units and cooling towers. Exhausted Freon from refrigeration units is recycled through a refrigerant and recovery/recharging system.

\subsubsection{Energy Management}

In 1991, the GJPO recognized the need to develop plans and procedures to comply with DOE Order 4330.2D, In-House Energy Management. In response to the Order, energy consumption progress reports are submitted to the DOE Headquarters Energy 
Management Branch each quarter. To increase the efficiency of energy use on the facility, energy-saving devices are routinely installed in buildings, and energy conservation measures are practiced. Some of the actions currently being implemented include replacing existing windows with insulated glass windows; upgrading heating, ventilating, and air conditioning systems; installing occupant sensors on light fixtures; installing heatrecovery equipment in certain laboratory fume hoods; purchasing and operating methane-powered vehicles; encouraging car-pooling; and switching off equipment when not in use. Maintenance personnel install energy-efficient devices in accordance with industry standards (American Society of Heating, Refrigerating and Air-Conditioning Engineers, Inc. 1993).

In general, nonregulated wastes generated during installation activities are disposed of at the Mesa County landfill. Potential regulated wastes occasionally are generated during replacement of equipment and fixtures. Pre-1979 fluorescent light fixture ballasts are assumed to contain PCBs and are stored in accordance with regulations under the Toxic Substances Control Act (TSCA) (15 U.S. Code Sections 2601-2692). As regulated materials, they are shipped to an off-site commercial facility for treatment and disposal. Fluorescent light fixture ballasts manufactured after 1979 are not regulated for PCBs and are shipped to the Mesa County landfill as they are replaced. Mercury lamps are shipped to a mercury recycling facility.

\subsubsection{Building Renovation}

Many of the facility's buildings, constructed during the 1940s and 1950s, require renovations to maintain their structural viability or to update their function. Renovation activities include asbestos abatement, room and building remodeling, ventilation modification, roof repair, exterior lead paint removal, and interior and exterior rehabilitation. On-site or subcontracted personnel perform renovation activities in accordance with 29 CFR Part 1910, "Occupational Safety and Health Standards," and 29 CFR Part 1926, "Safety and Health Regulations for Construction."

Nonregulated wastes generated from renovation activities are disposed of at the Mesa County landfill. Wastes that may qualify as regulated are characterized prior to disposal. Any lead-based paint that is removed from buildings is tested for lead content and, depending on the lead's leachability, may be managed as a hazardous waste (see Definitions section) in accordance with the Resource Conservation and Recovery Act (RCRA) (42 U.S. Code Sections 6901-6991i). If the waste is determined to be hazardous, it is shipped to a commercial facility for treatment and disposal. If UMT waste is encountered during routine renovation, it is shipped to the UMTRA Cheney Disposal Cell or to an approved commercial facility. 


\subsubsection{Asbestos Abatement}

On-site personnel and qualified subcontractors routinely remove asbestos-containing materials from facility buildings during renovation. In 1993, Rust Geotech (Rust) (prime contractor to DOE-GJPO) was issued a General Contractor Abatement Certificate by the Colorado Department of Public Health and Environment (CDPHE). Abatement is conducted in compliance with State and Federal requirements, including Colorado Revised Statutes Section 25-7-101, Colorado Regulation 8, Part B, "Asbestos Control;" 40 CFR Part 61, Subpart M, "National Emission Standard for Asbestos;" 29 CFR Section 1910.1001, "Occupational Safety and Health Standards, Asbestos;" 29 CFR Section 1926.58, "Safety and Health Regulations for Construction, Asbestos;" and 40 CFR Part 763, "Asbestos." If the removed materials are not radiologically contaminated, they are disposed of at the Mesa County landfill; radiologically contaminated asbestos is disposed of at the UMTRA Cheney Disposal Cell. Off-site shipping of asbestoscontaining materials is conducted in compliance with U.S. Department of Transportation regulations (49 CFR Parts 101-178).

\subsubsection{Road Renovation and Maintenance}

Road renovations and maintenance conducted at the GJPO facility include resurfacing, restriping, crack sealing, patch and repair work, and gravel road repair. Repairs are necessitated by degradation and by excavations for underground line repair or replacement. On-site personnel conduct small-scale asphalt repairs; off-site subcontractors usually perform all other repairs and disposal.

\subsubsection{Facility Ground Maintenance}

Subcontracted and Rust personnel perform ground maintenance on the facility on a routine basis. Subcontractors maintain lawn and vegetation areas and apply all pesticides, herbicides, and fertilizers. During the winter months, Rust personnel remove snow and ice from the facility. Equipment used for lawn care consists of small tractors, lawn mowers, "weed eaters," graders, and backhoes. Pesticides, herbicides, and fertilizer are applied and disposed of by personnel having current valid commercial applicators' and operators' licenses issued by the Colorado Department of Agriculture. Table 1 lists chemical products that are routinely used on the site; none of the products are stored on the facility. Commercial fertilizers are applied about four times a year during the growing season. Snow and ice are removed by plowing and sanding the sidewalks and roads. To prevent ice buildup, a commercial "deicer" is applied to the sidewalks. Application and use of commercial fertilizers and deicer conform to the manufacturers' directions. 
Table 1. Chemical Products Used at the GJPO Facility for Ground Maintenance

\begin{tabular}{|c|c|c|c|c|c|c|c|}
\hline Chemical Product" & Active Ingredient & $\begin{array}{c}\text { EPA } \\
\text { Registration } \\
\text { Number }\end{array}$ & $\begin{array}{l}\text { Restricted } \\
\text { Use }\end{array}$ & Target Pest & $\begin{array}{l}\text { Application } \\
\text { Form }\end{array}$ & $\begin{array}{l}\text { Mixture Ratio } \\
\text { (with water) }^{\mathbf{b}}\end{array}$ & $\begin{array}{l}\text { Application } \\
\text { Frequency }\end{array}$ \\
\hline Krovar II DF & Bromacil & $352-440$ & No & Vegetation & Granule & $8 \mathrm{lb} / 100 \mathrm{gal}$ & $1-2 /$ year \\
\hline Amitrol $T$ & Amitrole & $264-135-Z A$ & Yes & Vegetation & Liquid & $1 \mathrm{gal} / 100 \mathrm{gal}$ & $1-2 /$ year \\
\hline Fertilizer & Liquid Iron & Not Required & No & Vegetation & Liquid & $1 \mathrm{lb} / 100 \mathrm{gal}$ & $2-4 /$ year \\
\hline Urea & Calbamide & Not Required & No & Soil Organisms & Granule & $25 \mathrm{lb} / 100 \mathrm{gal}$ & $2-4 /$ year \\
\hline Karmex & Diuron & $352-247$ & No & Vegetation & Powder & $8 \mathrm{lb} / 100 \mathrm{gal}$ & $1-2 /$ year \\
\hline Princep Caliber 90 & Simazine & $100-603$ & No & Vegetation & Granule & $2 \mathrm{lb} / 100 \mathrm{gal}$ & $1-2 /$ year \\
\hline D-ZNN Diazinon 50W & Diazinon & $100-640$ & No & Insects & Powder & $1 \mathrm{lb} / 100 \mathrm{gal}$ & $1-2 /$ year \\
\hline Dacthal W-75 & $\begin{array}{l}\text { Dimethyl } \\
\text { Tetrachlorotere- } \\
\text { phthalate }\end{array}$ & $677-262$ & No & Vegetation & Liquid & $1 \mathrm{gal} / 100 \mathrm{gal}$ & $1-2 /$ year \\
\hline RQ Malathion DSMA & $\begin{array}{c}\text { Disodium } \\
\text { Methanearsonate }\end{array}$ & $50534-27-427$ & No & Insects & Liquid & $1 \mathrm{gal} / 100 \mathrm{gal}$ & 1-2/year \\
\hline Super Weed-No-More & Isocotyl Ester & $2217-651-3395$ & No & Vegetation & Liquid & $2 \mathrm{gal} / 100 \mathrm{gal}$ & $1-2 /$ year \\
\hline Sevin 50W & Carbaryl & $33955-27-3395$ & No & Insects & Powder & $12 \mathrm{lb} / 100 \mathrm{gal}$ & $1-2 /$ year \\
\hline Hyvar X-L & Bromacil & $352-346$ & No & Vegetation & Liquid & $1 \mathrm{gal} / 75 \mathrm{gal}$ & $1-2 /$ year \\
\hline Tempo $20 \mathrm{WP}$ & Cyano & $3125-380$ & Yes & Insects & Powder & $1 \mathrm{oz} / \mathrm{gal}$ & monthly \\
\hline
\end{tabular}

${ }^{a}$ Chemicals are disposed of by a subcontractor and not stored on the GJPO facility. ${ }^{b_{l} \mathrm{~b}}=$ pound; $\mathrm{gal}=$ gallon; $\mathrm{oz}=$ ounce . 


\subsubsection{Maintenance Shop Activities}

Various maintenance shops support the routine maintenance activities and fabrication and modification tasks required by special projects. These shops, located in Building 28 , consist of an electrical shop, carpenter shop, paint shop, welding shop, and sheet metal/plumbing shop. On a nonroutine basis, small amounts (less than 1 kilogram [2.2 pounds]) of hazardous waste are generated by the maintenance shops; wastes include spent solvents from the cleaning of paint brushes and paint thinners. These wastes are temporarily stored in a satellite accumulation area in Building 28 and periodically transported to the Waste Accumulation Modules (Buildings 61A, 61B, and 61C). From there, they are shipped to a commercial facility for treatment and disposal.

\subsubsection{Site Security}

Employees, visitors, property, and sensitive information at the GJPO facility are protected by a site security program developed and implemented by on-site security specialists. The program is based on the 5600 series of DOE orders, and the primary focus is on property protection. The facility is classified as a Class "PP" facility (i.e., "property protection"). Property and information are protected from acts of arson, civil disorder, riot, sabotage, terrorism, vandalism, and theft at a level consistent with their value.

Access to and egress from the facility are controlled at all times by security personnel and by an 8-foot, barbed-wire-topped, chain-link fence. Four authorized access points, attended by security officers, are located along the security fence. Access is available through three pedestrian gates and one vehicle gate. Two of the pedestrian gates are open during normal working hours; the third pedestrian gate and the vehicle gate are attended 24 hours a day, 7 days a week. All other nonpublic gates along the security fence are locked 24 hours a day, and ingress and egress are controlled by security officers.

\subsubsection{Emergency Preparedness}

A GJPO Emergency Preparedness and Response Plan (DOE 1994b) has been developed to minimize the impact of an emergency or unusual occurrence on the health and safety of GJPO personnel and the general public. The plan identifies the work force and equipment available to cope with emergency situations that could confront the GJPO. Emergency situations covered by the plan include fires, floods, natural or civil emergencies, demonstrations by activists or other groups, bomb threats, oil spills, radiological releases, enemy attacks, unplanned external investigations, and hazardous material releases. To verify the accuracy of the lists of personnel who are assigned actions, the plan is reviewed weekly by Health, Safety, and Security personnel. An annual assessment of the plan is conducted by Quality Assurance personnel. 


\subsubsection{Site Safety Assessment}

Health, Safety, and Security personnel completed a safety assessment for the GJPO facility in March 1994 (DOE 1994a). The assessment (1) identified hazards on the GJPO facility; (2) described and analyzed the adequacy of measures taken to eliminate, control, or mitigate identified hazards; and (3) analyzed and evaluated potential accidents and their associated risks.

On the basis of the safety assessment and hazards encountered on the GJPO facility, the facility is considered to be a low-hazard, nonnuclear facility. The safety assessment concluded that risk and impact to the public from facility operations are negligible. In addition, GJPO personnel are subjected to the same negligible risks and impacts as the public, only to a slightly greater degree because of their proximity to GJPO operations. GJPO personnel are subjected to risks and impacts from routine operations, including direct exposure to various radioactive sources (e.g., radon gas, $\mathrm{X}$-rays, and neutron borehole logging sources), hazardous materials, and hazards from cryogenic materials. These risks and impacts are negligible under normal operating conditions because of health and safety policies, procedures, training, and quality assurance programs. On-site personnel are expected to actively support and participate in the radiation protection program and continually work towards ensuring that radiation exposure is kept as low as reasonably achievable.

\subsubsection{Extremely Hazardous Substances}

DOE-GJPO maintains a Chemical Tracking System that tracks the purchase of all chemicals used on the facility. Extremely hazardous substances on the GJPO facility are not maintained in quantities that equal or exceed their respective threshold planning quantities as listed in 40 CFR Part 355, "Emergency Planning and Notification."

Hazardous chemicals subject to Tier I or II reporting under the Superfund Amendments and Reauthorization Act (SARA) Title III (40 CFR Part 370, "Hazardous Chemical Reporting: Community Right-to-Know") are present on the GJPO facility but are not in quantities required to be reported.

\subsubsection{Laboratories}

Laboratory personnel provide technical support to DOE, U.S. Department of Defense, EPA, other Federal and State agencies, and joint DOE-university studies. Services of the Analytical Laboratory, Petrology Laboratory, Sample Preparation Plant, Radon Laboratory, Environmental Sciences Laboratory, and Environmental Instrumentation Laboratory are available on the GJPO facility. 


\subsubsection{Analytical Laboratory}

The Analytical Laboratory (Building 20) is a full-service laboratory equipped to perform analyses of environmental samples. Services include analysis of radionuclide, inorganic, and organic samples in a variety of matrices-water, soil, vegetation, and tissue.

The laboratory generates a variety of waste streams by three primary pathways: effluent to the sewer system, emissions to the atmosphere, and regulated wastes that are accumulated in satellite accumulation areas. Liquid effluents discharged to the sewer system consist mainly of process wastes and aqueous sample residues, which are manually neutralized by laboratory personnel before being disposed of into the sewer system. An additional source of corrosive discharge to the sewer system, which is not neutralized, is the liquid effluent from the perchloric scrubbers. Sewer effluent is subject to restrictions imposed by the GJPO Industrial Pretreatment Permit issued by the city of Grand Junction.

Emissions from laboratory operations are vented to the atmosphere through fume hoods, which are used by laboratory personnel to limit their exposure to hazardous materials. In 1991, the CDPHE granted DOE-GJPO an air emission permit for the Analytical Laboratory's emissions. The permit establishes limitations on (1) the annual emissions of particulate matter, volatile organic compounds, and benzene; (2) the annual consumption of acids, volatile organic compounds, and benzene; and (3) the opacity of the emissions. No limits have been exceeded since issuance of the permit.

Regulated wastes generated by the laboratory are classified as hazardous, mixed, PCB, low-level, PCB/low-level combination, or solid nonhazardous (see Definitions section). Because of the varied analytical techniques employed by the laboratory, the resulting waste streams vary by constituent and volume. Hazardous wastes include end products of analytical processes and excess chemicals that are either unusable or outdated. Mixed wastes include expired calibration standards. PCB wastes are generated from the analysis of environmental samples containing regulated levels of PCBs. Low-level wastes include counting media, liquid scintillation cocktails, and excess or unused radiochemical inventory. Solid nonhazardous wastes are generated by routine laboratory activities.

Hazardous, mixed, and low-level wastes are stored in designated satellite accumulation areas in the laboratory and periodically are transported to the Waste Accumulation Modules in Buildings 61A, 61B, and 61C or the Hazardous and Mixed Waste Storage Unit (Building 42). PCB wastes are stored in a TSCA-compliant satellite accumulation area in Room 23 of the Analytical Laboratory and in the TSCA-compliant Hazardous and Mixed Waste Storage Unit.

Laboratory personnel follow procedures in the Analytical Chemistry Laboratory Chemical Hygiene Plan (Rust Geotech 1994a) during handling of chemicals, samples, and wastes to reduce or eliminate their exposure to toxic or hazardous substances. The plan, which complies with Occupational Safety and Health Administration regulations promulgated at 29 CFR Sections 1910.1000 and 1910.1450 , presents proper procedures for handling acids, cryogenic liquids, compressed gases, chemicals, and wastes. 


\subsubsection{Petrology Laboratory}

The Petrology Laboratory (in Building 7) is equipped to perform petrographic and mineralogic analyses of sedimentary, igneous, and metamorphic rocks. Analyses are performed with polarizing microscopes and an X-ray diffraction system. Other operations conducted at the laboratory include airborne asbestos and silica quantitative analysis, grain-size analysis, mineral separation, thermal analysis, qualitative identification of asbestos species, and quantitative measurement of asbestos in bulk insulation and other building materials.

Airborne asbestos analysis is conducted under a conventional fume hood fitted with a high-efficiency particulate air (HEPA) filter. Exhaust from this fume hood is discharged to the atmosphere. Bulk asbestos analysis is conducted in a safety enclosure with a built-in HEPA filtration system that exhausts air back into the room. In 1991, the CDPHE issued DOE-GJPO an air emission permit for Petrology Laboratory emissions to the atmosphere. Because of June 1993 revisions in the State hazardous air pollution regulations and because of the low pollutant levels being emitted, the State exempted Petrology Laboratory emissions from permit requirements in January 1994.

Hazardous waste, in the form of spent solvents, is generated in the Petrology Laboratory from sample preparation and cleaning operations. This waste is accumulated in a satellite accumulation area in Room 141 and is periodically transported to either the Waste Accumulation Modules or the Hazardous and Mixed Waste Storage Unit.

Personnel who work in the Petrology Laboratory follow procedures in the Analytical Chemistry Laboratory Chemical Hygiene Plan (Rust Geotech 1994a) and Handbook of Petrology Laboratory Methods (Rust Geotech 1994d) to reduce or eliminate their exposure to chemicals and asbestos fibers. These procedures are implemented in accordance with Occupational Safety and Health Administration regulations at 29 CFR Section 1910.1450 .

\subsubsection{Sample Preparation Plant}

The Sample Preparation Plant (west side of Building 7) is a full-service sample preparation facility that receives, prepares, and stores samples for chemical and petrographic analyses. In the course of their work, personnel follow procedures in the Analytical Chemistry Laboratory Chemical Hygiene Plan (Rust Geotech 1994a) to reduce or eliminate their exposure to potentially hazardous chemicals. The primary environmental concerns associated with the plant are air emissions and sample storage.

Dust from the preparation of environmental samples may contain crystalline silica and minor amounts of radioactive materials and heavy metals. During preparation of these samples, emissions are vented to a Baghouse filtration system before they are released to the atmosphere. Emissions from the Baghouse are continuously monitored by an 
automatic system. Baghouse emissions must comply with the dose limits for DOE facilities established by 40 CFR Part 61, Subpart H, "National Emission Standards for Emissions of Radionuclides Other Than Radon from DOE Facilities" and DOE Order 5400.5, Radiation Protection of the Public and the Environment. The radioparticulate dose resulting from Baghouse emissions (0.00006 millirem per year [mrem/yr]), is a small fraction of the EPA and DOE standard of $10 \mathrm{mrem} / \mathrm{yr}$ for the facility as a whole. The CDPHE issued an air emission permit for the Baghouse to DOE-GJPO in 1991. Because of 1993 regulation revisions and the low levels of pollutants being emitted, the State exempted Baghouse emissions from permit requirements in January 1994.

Personnel at the Sample Preparation Plant administer a sample storage area in Building 33. Most of the stored samples are from characterization and remedial verification activities conducted at vicinity properties and inactive millsites under UMTRA and at the GJPO facility. These samples are not disposed of until written authorization is received from the responsible project/program manager and until a proper disposal method, meeting regulatory requirements, is determined. Other material stored in Building 33 includes approximately 47 cubic meters (61 cubic yards) of PCBcontaminated UMT waste. EPA has concurred with the proposed disposition of these materials at the UMTRA Cheney Disposal Cell. Disposal is planned prior to midcalendar-year 1996, contingent upon weather conditions.

\subsubsection{Radon Laboratory}

Personnel at the Radon Laboratory test, evaluate, calibrate, and develop devices used to measure radon gas and radon daughters (decay products of radon gas). The Radon Laboratory facility consists of an alpha-track radon calibration chamber, radon calibration system, radon/radon-daughter environmental chamber, charcoal-canister radon chamber, glass chamber, and radon barrel. To reduce or eliminate their exposure to radon and other radioactive sources, laboratory personnel follow procedures in the Radon Laboratory Procedures (Rust Geotech 1994f) and Radon/Environmental Sciences Laboratories Chemical Hygiene Plan (Rust Geotech 1994e).

The average radon-222 emission from the principal sources used routinely in Radon Laboratory operations is approximately 0.34 curie (see Definitions section) per year $(\mathrm{Ci} / \mathrm{yr})$. This amount does not affect ambient air concentrations of radon at the facility boundary, which are regulated by DOE Order 5400.5. Table 2 lists the two main sources of radon and their associated emission.

Alpha-Track Radon Calibration Chamber: The alpha-track radon calibration chamber in Building 31A is used to calibrate small, passive alpha-track or similar radon-measuring devices. A controlled quantity of radon gas is bled into a controlled air stream, passed through the chamber vessel, and exhausted to the atmosphere through a purge line on the east side of Building 31A. Radon gas also can be exhausted directly to the atmosphere through a bypass line. 
Table 2. Summary of Radon Emissions From Sources Used in the Radon Laboratory

\begin{tabular}{||l|c|c|c||}
\hline \multicolumn{1}{|c|}{ Source } & Building & $\begin{array}{c}\text { Radium-226 } \\
(\mathbf{C i})^{2}\end{array}$ & $\begin{array}{c}\text { Radon-222 Production } \\
\text { Rate } \\
(\mathbf{C i} / \mathbf{y r})\end{array}$ \\
\hline \hline Total Pylon Flow-Through & $31 \mathrm{~A} / 32$ & $1.579 \times 10^{-4}$ & $1.0 \times 10^{-2}$ \\
\hline Radon Barrel & 33 & $5.0 \times 10^{-3}$ & $3.3 \times 10^{-1}$ \\
\hline \hline \multicolumn{2}{|r}{ Total Radon-222 } & $3.4 \times 10^{-1}$ \\
\hline
\end{tabular}

${ }^{2}$ Scientific notation $5.0 \times 10^{-3}=0.0050$.

Radon Calibration System: The radon calibration system in Building 31A is used to calibrate continuous radon-monitoring devices. A controlled quantity of radon gas is bled into a controlled air stream via a polyvinyl chloride pipe and is exhausted to the atmosphere through a purge line on the east side of Building 31A. Radon gas also can be exhausted directly to the atmosphere through a bypass line.

Radon/Radon-Daughter Environmental Chamber: The radon/radon-daughter environmental chamber in Building 32 is an environmentally controlled cylindrical vessel in which air containing radon is circulated to calibrate, test, and evaluate radon and radon-daughter measuring instruments. Environmental parameters such as radon concentration, ventilation rate, temperature, dew point, and condensation-nuclei concentration can be controlled. Typically, chamber radon concentrations range from 5 to 100 picocuries per liter $(\mathrm{pCi} / \mathrm{L})$. Occasionally, a thoron (radon-220) source with calculated concentrations ranging from 30 to $900 \mathrm{pCi} / \mathrm{L}$ is used in experiments. During the experiments, radon-220 is isolated within the chamber. Venting to the atmosphere does not occur because radon-220 has a half-life of only 55 seconds, and it decays within the chamber. Emissions to the atmosphere occur only at the conclusion of the experiment when the chamber is flushed briefly with room air. Exhaust air from the chamber is vented through a stack on the west side of Building 32. The gaseous effluent streams exhausted through the stack originate from three sources: the purge/bypass line of the radon generator, the exhaust baffle in the area of the radon generator, and the exhaust-system line for the radon chamber.

The radon/radon daughter environmental chamber is the only one of the chambers that physically can be entered by laboratory personnel. Procedures for entry into the chamber are defined in the "Radon Daughter Chamber Operating Procedure" of the Radon Laboratory Procedures (Rust Geotech 1994f).

During operation of the chamber, butanol is used in the condensation-nucleus counter to determine the concentration of particles in the air. This hazardous waste is periodically drained from the counter and accumulated in the satellite accumulation area in Room 10, Building 31A. Approximately 20 milliliters is generated every other month. 
The accumulated butanol is collected annually and transported to either the Waste Accumulation Modules or the Hazardous and Mixed Waste Storage Unit.

Charcoal-Canister Radon Chamber: The charcoal canister radon chamber in Building 32 primarily is used to calibrate large quantities of charcoal-type radon detectors. Relative humidity, which affects charcoal-type devices, is controlled within the chamber. This chamber is designed as a low-cost alternative to the larger environmental chamber. Radon gas is exhausted through an activated charcoal trap that discharges into the chamber room of Building 32 .

Glass Chamber: The glass chamber in Building 32 is used to determine long-term average radon exposure through measurement of alpha activity from polonium-210embedded glass. As many as 20 pieces of glass can be contained within a 55-gallon drum. Radon gas is bled into a controlled air stream, passed through the chamber, and exhausted to the atmosphere from the east side of the building.

Radon Barrel: The radon barrel is a 5-millicurie radon source (radium-226) in a 30-gallon drum. The source, which is located in the south end of Building 33, is used in a variety of experiments. Radon emissions from the source are occasionally exhausted to the atmosphere.

\subsubsection{Environmental Sciences Laboratory}

The Environmental Sciences Laboratory consists of four laboratories in which research is conducted in geochronology, ecology, hydrogeochemistry, and subsurface transport of contaminants. The facility consists of two wet labs with sinks, two dry labs, one fume hood, two exhaust vents for the atomic absorption spectrometers, a gas chromatograph, and an ion chromatograph. To minimize their exposure to chemicals and radioactive sources, laboratory personnel follow procedures in the Radon/Environmental Sciences Laboratories Chemical Hygiene Plan (Rust Geotech 1994e). Small quantities (less than 20 kilograms per year) of experimental residue, waste, and effluent are generated and managed in accordance with applicable regulations.

The primary mission of the Environmental Sciences Laboratory is to facilitate and perform multidiscipline research activities in support of environmental restoration and geoscience projects at DOE sites nationwide. Current projects focus on:

- Chemical Barriers: placing barrier materials in the subsurface to inhibit migration of metals, radionuclides, and organics in groundwater.

- Coupled Hydrogeochemical Modeling: conducting groundwater modeling that couples chemical reactions with transport codes to yield more rigorous performance assessments. 
- Tree-Ring Chemistry: examining the chemistry of growth rings in woody plants for evidence of pollution chronologies.

- Waste-Site Lysimetry: evaluating the reliability of using small weighing lysimeters to determine recharge at waste disposal sites.

- Geochronology: measuring the five noble gases (helium, neon, argon, krypton, and xenon) and conducting geochronology studies by the uranium-thorium-helium and potassium-argon dating methods using isotope dilutions. Measurements are made on a variety of matrices, including water, gas, and rock, with a mass spectrometer. In addition, samples are processed off site for carbon-14 and tritium analyses.

- Hydroprobe Comparison: comparing the performance of a hydroprobe that uses capacitance with one that uses a neutron source to measure soil-water content.

- Analogs of Long-Term Performance: investigating natural analogs of the effects of climate change, soil development processes, and plant succession on the long-term performance of engineered waste-site covers.

\subsubsection{Environmental Instrumentation Laboratory}

The Environmental Instrumentation Laboratory in Building 3022 provides on-site support for a wide variety of instruments and systems, primarily those having environmental, geophysical, and laboratory applications. Services provided include calibration, repair, preventive maintenance, design, modification, and fabrication. Facilities in which these services are provided are the main laboratory, high-bay area, model shop, and gammaray exposure-rate range.

The model shop accounts for the majority of the fabrication equipment, which consists of lathes, milling machines, welders, band saws, drill presses, a punch press, and numerous other working tools. Instrument parts or systems can be fabricated from plastic, stainless steel, aluminum, and other materials.

Approximately 14 kilograms ( 30 pounds) of hazardous waste, in the form of nickel/cadmium batteries and miscellaneous chemicals, is generated annually by the laboratory. These wastes are temporarily stored in a satellite accumulation area in Building 3022, transported to the Waste Accumulation Modules, and disposed of as RCRA wastes. Other wastes generated by the lab, such as used lead/acid batteries, electrical wire scraps, and scrap metal, are recycled by off-site contractors.

Two sources of potentially hazardous air emissions are associated with the Environmental Instrumentation Laboratory. During routine welding activities in the model shop, metal fumes are exhausted through two fume hoods and a stack to the atmosphere. Emissions from internal combustion engines generated during experimental testing of specialized vehicles and equipment in the high bay are exhausted through a 
system of flexible metal tubing along the ceiling and a stack to the atmosphere. Chemical constituents within the emissions, which include carbon monoxide, nitrogen oxides, and hydrocarbons, are below reporting thresholds for hazardous or criteria pollutants (listed in the Colorado Air Quality Control Commission's Regulation Number 3).

\subsubsection{GJPO Tenant Operations}

\subsubsection{Oak Ridge National Laboratory Operations}

ORNL operates independently under a contractual agreement with the DOE Oak Ridge Operations Office. At the GJPO facility, one of ORNL's missions is to conduct radiological assessments and independent verification surveys in support of remedial action programs. Other work performed by ORNL directly supports other Government programs. ORNL's on-site operations are administrative, except for the sample preparation and analytical facilities' activities, groundwater monitoring, and occasional on-site radiological assessments performed in support of GJPORAP.

The ORNL Sample Preparation Facility in Building 56 receives, prepares, and stores uranium mill tailings samples for radionuclide analysis. During sample preparation, an air evacuation filtration system that recirculates HEPA-filtered air emissions back into the room is operated.

Analyses of uranium mill tailings samples are performed in the Soil Analytical Laboratory (in Building 56) by gamma spectrometry for radium-226, thorium-232, and potassium-40. After analyses, these samples are temporarily stored in 55-gallon drums in controlled areas west of Building 56 and north of Building 55. Long-term storage is provided in Building 33. Eventually, UMTRA and GJPORAP samples will be disposed of at the UMTRA Cheney Disposal Cell, and Monticello Remedial Action Project samples will be disposed of at the Monticello Repository.

\subsubsection{Los Alamos Core and Sample Repository}

The Los Alamos Core and Sample Repository was established in 1985 to accumulate and archive geologic samples obtained from geothermal boreholes drilled by the DOE Office of Basic Energy Sciences and other groups. The purposes of the Los Alamos Core and Sample Repository are to provide the scientific community with ready access to geologic samples and information, ensure proper preservation and storage of samples and data, maintain records of sample requests, and promote the use of sample inventory and data by qualified investigators. Presently, about 13,900 meters ( 45,000 feet) of drill core are stored in the repository. None of the drill core contains radioactive or hazardous materials. 


\subsubsection{General Senvices Administration}

The General Services Administration in Building 28 manages an Area Fleet Office for approximately 725 government vehicles, which are supplied to about 65 different Federal agencies and subcontractors. Vehicle maintenance, fueling, and repairs are subcontracted off site. Activities of General Services Administration employees are administrative only.

\subsubsection{U.S. Army Reserve}

The U.S. Army Reserve leases approximately 8 hectares (19.5 acres) in the north portion of the facility for storing bridge parts and conducting training (Gouldsberry 1995). No fueling or vehicle maintenance is conducted on the facility.

\subsubsection{Environmental Restoration Activities}

The removal of all known exterior UMT waste under GJPORAP was completed on July 1, 1994. Other work performed under this program has included:

- demolition of Buildings $6,31,39,44$, and 52. These buildings were demolished because they could not reasonably be decontaminated to meet DOE's criteria for conditional or free release. Building 6 was replaced with a new building.

- removal of UMT waste from Buildings 18 and 28.

- encapsulation of UMT waste in Buildings 7 and 34.

Activities associated with building remediation under GJPORAP include (1) assessment of the radiologically contaminated areas (size of area, volume of material) that will be remediated, (2) design of the remedial action and preparation of a procurement package, (3) decontamination or demolition of the building, (4) verification of contamination removal, and (5) documentation of remedial action completion.

A complete assessment of the size of area and volume of material to be remediated within a building often is not possible because of the physical location of the materials or the high cost of characterization. In these cases, materials are characterized and segregated during remedial action. After the initial assessment, DOE prepares the remedial design and bid package for conducting the remedial action. If a building is to be demolished, DOE obtains approval from the U.S. Department of Housing and Urban Development in accordance with the requirements of the Stewart B. McKinney Homeless Assistance Act.

Buildings may be decontaminated by using a variety of methods, depending upon the type, location, or form of contamination. Typical methods include use of pressurized 
water, blasted jets of steel shot (usually onto concrete surfaces), vacuum units containing HEPA filters, or scabbler units; or, the contaminated material is simply removed. The entire building is removed during demolition. Larger buildings usually are dismantled piece by piece by workers using cutting blades, lifting equipment, structural support equipment, trackhoes, and front-end loaders. Smaller buildings such as storage sheds may be pushed down with a front-end loader. No explosives are used for demolition.

The types of material removed during decontamination and demolition may include UMT waste, mixed waste, asbestos, uncontaminated solid waste, and salvageable material. These materials are collected and segregated on site before being transported off site. UMT wastes are transported to the UMTRA Cheney Disposal Cell or to an approved commercial facility. The specific transportation route to the UMTRA Cheney Disposal Cell is authorized in a Conditional Use Permit with Mesa County (Mesa County 1988), and the environmental impacts associated with it are discussed in the Environmental Impact Statement for the Climax Mill Site (DOE 1986) and the Administrative Record; Grand Junction Projects Office Remedial Action Project, Direct Truck Haul of Residual Radioactive Material to the Cheney Repository (DOE 1993a). Other UMT wastes (e.g., contaminated equipment, fixtures, instruments, test pits, or calibration pads) may be transported to an approved commercial facility. Mixed wastes are managed in accordance with RCRA regulations (see Sections 3.1.7.1 and 3.1.7.4). Asbestos and uncontaminated solid wastes are transported to the Mesa County landfill, and salvageable materials are sold to off-site buyers.

During decontamination and demolition activities, workers follow the procedures in the GJPORAP Health and Safety Plan (DOE 1995d). This plan outlines the requirements for personal protective equipment, worker training, medical surveillance, exposure monitoring, project site control, decontamination, emergency response, confined space entry, and spill response. Implementation of the plan reduces potential exposure to workers and potential accidents at the construction site.

Once a building has been decontaminated or demolished, the removal of contaminated material is verified by both the GJPORAP contractor and the independent verification contractor (ORNL). Release criteria is established by EPA in 40 CFR Part 192 for soils and habitable buildings and by DOE Order 5480.5 for surface contamination on building interiors and exteriors and structural surfaces (e.g., concrete, asphalt).

A Closeout Report documents the completion of the remedial action. Prepared by the GJPORAP contractor and submitted to DOE, the report includes a brief history of the building, a description of the contamination and how it was removed, results of the verification survey, and the specific release criteria used for the building.

A building may or may not be replaced if it was demolished, depending upon the need for storage, office, or laboratory space. If a building is replaced, construction of a new building is designed in accordance with the Uniform Building Code (International Conference of Building Officials 1994) and with DOE Order 6430.1A, General Design Criteria. 


\subsubsection{Other GJPO Operations}

Other operations on the GJPO facility that may affect the environment include those associated with the on-site medical facility, instrument calibration facilities, copying services, and on-site food service.

\subsubsection{On-Site Medical Facility}

The Occupational Health Program Clinic is located on the east end of Building 54. The clinic is a dispensary that provides a variety of services, including (1) worker's compensation case management, (2) back injury prevention training, (3) cardiopulmonary resuscitation and first aid training, (4) physical examinations, (5) drug screen urinalysis, (6) ergonomic evaluations, (7) wellness programs, (8) health counseling, (9) gatekeeper service for Employee Assistance Program, and (10) seminars on health topics. Presently employed at the clinic are two full-time registered nurses (one of whom is a certified occupational health nurse) and one subcontracted board-certified occupational medical physician.

Biomedical wastes (e.g., syringes, blood-contaminated products) are generated through first-aid care and employee physical examinations. These wastes are wrapped in puncture-proof packaging and accumulated in a dedicated biomedical waste container, which is located in a controlled-access area of the clinic. An approved subcontracted service collects and disposes these wastes.

\subsubsection{Instrument Calibration Facilities}

The GJPO's instrument calibration facilities, located west of Building 3022, consist of subsurface borehole models and small calibration pads. The facilities have evolved during the last 25 years. Initially, they were used to calibrate gamma-ray-measuring instruments used in uranium exploration, but more recently they have been used to calibrate instruments employed in the characterization of contaminated sites and verification of remedial action. The facilities contain distributed sources of radium, thorium, and/or potassium and, in general, were constructed by enriching a concrete mix with uranium ore, monazite sand, and/or orthoclase sand.

Maintenance of the calibration facilities is part of routine facility maintenance operations. A 50/50 mixture of ethylene glycol (antifreeze) and water is contained yearround in sealed borehole models that are partially above ground. When calibrations require a dry borehole, the mixture is pumped to a holding tank or drum for recycling.

Radon emissions from the instrument calibration facilities average about $0.18 \mathrm{Ci} / \mathrm{yr}$ (Kelleher 1994), which is about the same amount that is emanated from 3 acres of bare ground. 


\subsubsection{Copying Services}

An on-site Copy Center (Building 2) uses two industrial copiers to produce 5.2 million pages of copied material each year. Paper is the only waste product generated, and it is recycled. Toner used in the copiers is recycled within the machines themselves. Toner within convenience copiers, located throughout the facility, is removed and recycled by off-site personnel.

Ammonium hydroxide is generated by a microfilm duplication machine in Building 12 . It is accumulated in a satellite accumulation area in Room 19A and is periodically transported to either the Waste Accumulation Modules or the Hazardous and Mixed Waste Storage Unit.

\subsubsection{On-Site Food Service}

An on-site food service operates during morning and lunchtime hours in Building 46. Facilities include an electric grill, oven, freezer, and several refrigerators. The primary wastes generated include grease and solid wastes from food packaging and preparation, both of which are disposed of at the Mesa County landfill. Small amounts of grease, detergent, and food are washed into the sewer system but do not negatively affect compliance with the Industrial Pretreatment Permit.

\subsubsection{Research and Development Projects}

The GJPO's applied research and development activities provide personnel with opportunities to test new or improved techniques and concepts that support current or planned programs at the GJPO. These activities are funded primarily by two programs: the Program Support Research and Development program and the Technology Development Program.

The Program Support Research and Development program funds small projects in the areas of basic and applied research and development that focus on advanced study of new hypotheses, new concepts, or innovative approaches to scientific and technical problems. Projects are submitted for approval annually and may be funded for 3 years.

The Technology Development Program provides new and innovative methods and equipment for use in solving waste problems at DOE facilities. Project work focuses on the development of (1) geophysical and geochemical exploration equipment and methods for site characterization, (2) techniques for low-level radiometric waste cleanup and site restoration, (3) monitoring methods, (4) facilities and equipment for radionuclide and uranium-thorium-potassium daughter sensing, and (5) analytical services associated with these activities. Table 3 lists the Program Support Research and Development projects and the Technology Development Program projects selected for fiscal year (FY) 1994 and FY 1995. 
Table 3. Summary of GJPO Research and Development Projects for FY 1994 and FY 1995

\begin{tabular}{|c|c|}
\hline FY 1994 & FY 1995 \\
\hline $\begin{array}{l}\text { Program Support Research and Development } \\
\text { Data Sonification } \\
\text { Global Positioning System Integrated Geophysics } \\
\text { Aquifer Dispersivity Measurements } \\
\text { Glass Radon Studies } \\
\text { Pipe Scale Gauge } \\
\text { Alpha-Track Plant Measurements } \\
\text { Soil Permeability Gauge } \\
\text { Radon Diffusivity Gauge } \\
\text { Trichloroethylene Sorption } \\
\text { Technical Impracticability Waivers } \\
\text { Environmental Center Plan } \\
\text { Radionuclide Concentration Ratios } \\
\text { Carbonate Dissolution Effects } \\
\text { Solid-State Gamma-Ray Detector } \\
\text { Success of Revegetation Efforts } \\
\text { Climate-Change Workshop } \\
\text { Gradiometer Antenna Studies } \\
\text { Long-Range Alpha Detection Field Screening } \\
\text { Amorphous Ferric Oxyhydroxide Aging } \\
\text { Watts Bar Reservoir Sediment Accumulation } \\
\text { Radiation Instruments Checked Without } \\
\text { Radioactive Sources } \\
\text { Range Intercomparison } \\
\text { Air-Tracing Techniques } \\
\text { Technology Development Program } \\
\text { Tensor Magnetic Gradiometer } \\
\text { Broadband Electromagnetics } \\
\text { Integrated Borehole Logging } \\
\text { Characterization Technical Support Group } \\
\text { Dig-Face Characterization } \\
\text { Multispectral Logging } \\
\text { Rabbit Valley Geophysics Performance } \\
\text { Evaluation Range } \\
\text { Three-Dimensional/Three-Component } \\
\text { Reflection Seismic } \\
\text { Mixed-Waste Performance Evaluation Samples } \\
\text { Laboratory Management Division Support } \\
\text { Office of Sample Management Support } \\
\text { Technical Program Manager Support } \\
\text { Technology Program Management } \\
\text { Performance Measurement and Reporting Training } \\
\text { Frozen Soil Barriers-Arid Site Research } \\
\text { and Development } \\
\text { Program Environmental Impact Statement } \\
\text { Chemical Barrier Technology } \\
\text { Integrated Geophysics } \\
\text { Arid Volatile Organic Compound-Technical } \\
\text { Support Group } \\
\text { Regulatory and Risk Analysis of } \\
\text { Separations Technology } \\
\text { Very Early Time Electromagnetics } \\
\text { FERMCO }\end{array}$ & $\begin{array}{l}\text { Program Support Research and Development } \\
\text { Silicalite Adsorption } \\
\text { Scintillating Membrane } \\
\text { Cone Penetrometer Gamma Log } \\
\text { Oxygen Activation Density Log } \\
\text { Vegetation/Rock Revetments } \\
\text { Air-Tracing Techniques } \\
\text { Solid-State Crutch Scanner } \\
\text { Environmental Reference Episodes } \\
\text { Soil Hydrology Modeling } \\
\text { Spectral Analysis of Surface Waves Seismic Technique } \\
\text { Subterranean Gas Waves } \\
\text { Amorphous Ferric Oxyhydroxide Aging } \\
\text { Community College Network/Other Federal Agencies } \\
\text { Feasibility Determination } \\
\text { Geoeiectrical Dispersivity Measurements } \\
\text { Technology Development Program } \\
\text { Tensor Magnetic Gradiometer } \\
\text { Broadband Electromagnetics } \\
\text { Multispectral Logging } \\
\text { Rabbit Valley Geophysics Performance } \\
\text { Evaluation Range } \\
\text { Three-Dimensional/Three-Component Reflection Seismic } \\
\text { Mixed-Waste Performance Evaluation Samples } \\
\text { Laboratory Management Division Support } \\
\text { Office of Sample Management Support } \\
\text { Technical Program Manager Support } \\
\text { Technology Program Management } \\
\text { Performance Measurement and Reporting Training } \\
\text { Frozen Soil Barriers-Arid Site Research } \\
\text { and Development } \\
\text { Very Early Time Electromagnetics } \\
\text { FERMCO }\end{array}$ \\
\hline
\end{tabular}


Some of the research and development projects under the two programs could generate small quantities of regulated waste (i.e., less than 9 kilograms [20 pounds] per year of hazardous, low-level, or mixed waste); therefore, they are evaluated prior to their commencement to minimize waste generation. Most of the regulated wastes are groundwater and soil sample residues containing a hazardous or low-level component that result from experiments. Hazardous and mixed wastes are stored at or near their point of generation in satellite accumulation areas and are periodically transported to the Waste Accumulation Modules. Low-level wastes are accumulated in designated containers in Radiologically Controlled Areas in the laboratories and are periodically transferred to the Waste Accumulation Module (Building 61C).

\subsubsection{Waste Management}

The GJPO conducts a waste management program in accordance with DOE Order 5820.2A, Radioactive Waste Management; DOE Order 5480.3, Safety Requirements for the Packaging and Transportation of Hazardous Materials, Hazardous Substances, and Hazardous Wastes; the Performance Objective for the Certification of Nonradioactive Hazardous Wastes (Performance Objective) (DOE 1995g); and Federal, State, and local laws, regulations, and guidelines. Waste management activities are concerned with the minimization, accumulation, storage, and disposal of regulated and nonregulated wastes generated from activities at the facility. The types of wastes generated through GJPO programs and operations include hazardous, radioactive, mixed, PCB, asbestos, and solid nonhazardous wastes.

Since February 1992, the GJPO has operated as a conditionally exempt small quantity generator (CESQG) under RCRA regulations. Status as a CESQG is maintained when the following criteria are met: (1) less than 100 kilograms (220 pounds) of hazardous and mixed waste is generated per month, (2) less than 1 kilogram (2.2 pounds) of acute hazardous waste is generated per month, and (3) less than 1000 kilograms $(2,200$ pounds) of hazardous and mixed waste is accumulated on site at one time. In the event that DOE-GJPO would generate more than 100 kilograms of hazardous and mixed waste in 1 month (and be considered a small quantity generator [SQG]), administrative controls are fully in place to manage waste under an SQG status. These administrative controls include management of satellite accumulation areas, (2) use of uniform hazardous waste manifests for off-site shipments of hazardous and mixed wastes, (3) assignment of an EPA identification number to the GJPO facility, (4) preparation of waste profile information for all hazardous and mixed wastes generated, and (5) compliance with SQG training and reporting requirements.

In May 1991, DOE imposed a nationwide waste-shipment moratorium until sites could demonstrate that a program was in place for ensuring that radioactively contaminated hazardous wastes were not being transported off site for treatment and disposal. In December 1993, the waste moratorium was lifted for the GJPO facility through implementation of the Performance Objective (DOE 1995g). As part of the Performance Objective, radioactive materials management areas (RMMAs) were 
established at locations where waste potentially could become radiologically contaminated. These areas are inspected by designated RMMA managers and routinely monitored by health and safety personnel in accordance with the requirements defined for contamination areas in the Health and Safety Manual, Volume 2 (Rust Geotech 1995c). Waste management and health and safety personnel are responsible for initiating and discontinuing the use of RMMAs. The "RMMA Operating Criteria" in Procedure 5.4 of the Environmental Protection Manual (Rust Geotech 1995a) delineates responsibilities and management requirements for RMMAs.

All hazardous wastes generated on the facility are assessed for radiological contamination before they are disposed of or transported. The procedures used to certify wastes as nonradioactive or radioactive are described in the Performance Objective. In general, external radiation and contamination surveys, process knowledge, and/or sampling and analysis are used to make the determination. A staff Health Physicist then reviews the surveys and radiological analyses and certifies that the waste contains no DOE-added radioactivity.

\subsubsection{Waste Types}

Regulated wastes generated or transferred on site are identified and characterized for proper classification through the implementation of waste acceptance criteria. These criteria are established and implemented through Procedure 5.1, "Acceptance Criteria for Characterization, Certification, and Transfer of Radioactive, Hazardous, and Mixed Waste," in the Environmental Protection Manual (Rust Geotech 1995a). In accordance with this procedure, characterization is accomplished through sampling and analysis and/or through process knowledge. The following sections describe the waste types generated on the GJPO facility.

Hazardous Waste: Hazardous waste is designated hazardous under the Colorado Hazardous Waste Regulations (6 Colorado Code of Regulations Section 1007-3). The GJPO generates less than 100 kilograms per month of hazardous waste and thereby maintains the status of a CESQG. Wastes routinely generated include (1) obsolete chemicals, process waste resulting from analysis, and spent reagents from the Analytical Laboratory; (2) spent solvent from sample preparation and cleaning in the Petrology Laboratory; (3) spent ammonium hydroxide from the microfilm duplication machine in Building 12; (4) miscellaneous chemicals and nickel/cadmium batteries from the Environmental Instrumentation Laboratory; (5) small amounts of butanol used in counting instruments in the Radon Laboratory; and (6) spent reagents and residues from research activities from the Environmental Sciences Laboratory.

Radioactive Waste: Radioactive wastes that currently are stored, generated, or scheduled for remediation at the GJPO facility are categorized as either (1) UMT wastes or (2) low-level wastes. UMT wastes are managed similarly to residual radioactive materials, as defined under 40 CFR Part 192. These wastes were generated as a result of the historical processing of ores. Currently, they are generated during 
decontamination and demolition of on-site radioactively contaminated facilities and during renovation of facility buildings. UMT wastes may include equipment (e.g., fork lifts, saws, generators, welders, and tanks), laboratory instruments (e.g., ovens, heaters, washers, and blenders), light fixtures, test pits, and calibration pads.

Low-level wastes are radioactive wastes that are not classified as high-level waste, transuranic waste, spent nuclear fuel (see Definitions section), or UMT waste. Small quantities of liquid and solid low-level wastes are generated by on-site activities. The majority of liquid low-level wastes are generated by the Analytical Laboratory and commonly are in the form of tritium-based liquid scintillation cocktails. However, some liquid and solid low-level wastes are derived from obsolete, depleted, or unused radioactive sources obtained for instrument calibration and radiometric purposes. Additional solid low-level wastes include excess radiochemical product inventory, failed or obsolete contaminated equipment, contaminated laboratory trash, counting media, and spill material.

Mixed Waste: Mixed wastes that currently are stored, generated, or scheduled for remediation at the GJPO facility are categorized as either (1) mixed UMT waste or (2) mixed low-level waste. Mixed UMT waste contains both UMT waste and a RCRAregulated component as defined by 40 CFR Parts 261-268 and the Colorado Hazardous Waste Regulations. These wastes are subject to management consistent with RCRA. They were derived from on-site remedial activities and are stored at the GJPO facility in Building 61B and Building 42.

Mixed low-level waste contains both low-level waste and a RCRA-regulated component as defined by 40 CFR Parts 261-268 and the Colorado Hazardous Waste Regulations. Approximately 8 kilograms (18 pounds) of mixed low-level waste is generated annually from routine organic, inorganic, and radiochemical analyses performed by Analytical Laboratory staff or by various researchers at the facility. Mixed low-level wastes primarily originate from expired calibration standards and RCRA-based liquid scintillation cocktails.

PCB Waste: PCB wastes are those that contain PCBs in concentrations greater than $50 \mathrm{ppm}$ or those that contain less than $50 \mathrm{ppm}$ but are generated as a result of dilution of a regulated source of PCBs. These wastes are regulated under TSCA (40 CFR Part 761). PCB wastes generated on the facility include residues from the analysis of samples that contain greater than $50 \mathrm{ppm}$ PCBs and pre-1979 fluorescent light fixture ballasts that are replaced in on-site buildings.

Because the GJPO generates regulated PCB waste streams on a routine basis, the facility is subject to EPA notification requirements codified at 40 CFR Section 761.205. An annual PCB document log as required by 40 CFR Section 761.180 is prepared for all materials known or suspected to contain PCBs in regulated concentrations at the GJPO.

PCB-UMT Waste: In 1989, suspect PCBs mixed with UMT waste were excavated under GJPORAP and unintentionally placed in an on-site temporary UMT waste stockpile 
before the PCB analytical data had been reviewed. Recovery of the PCB materials resulted in dilution/volume expansion. Under EPA guidance, approximately 47 cubic meters of PCB-UMT waste was excavated and later stored in Building 33 within four roll-off bins. These wastes are inspected on a monthly basis (at a minimum), as required under 40 CFR Section 761.65. Other PCB-UMT wastes that may be generated at the GJPO facility are fluorescent light fixture ballasts that are removed during GJPORAP activities.

Asbestos Waste: Asbestos-containing waste materials are defined under the Colorado Emission Standards for Asbestos, Regulation Number 8, Part B. These materials are generated from abatement projects conducted on the GJPO facility. The DOE-GJPO contractor performs inspections and minor abatement work; subcontractors perform the more complex and extensive asbestos abatement jobs on the facility. All asbestos waste is surveyed for radioactive contamination before disposal.

Solid Nonhazardous Waste: Solid nonhazardous wastes are non-RCRA, nonradioactive, domestic wastes generated through routine operations at the GJPO facility. These wastes are stored in dumpster-type receptacles located throughout the facility.

\subsubsection{Waste Minimization}

DOE Order 5400.1, General Environmental Protection Program, requires DOE facilities to establish a waste minimization program aimed at minimizing waste volume and toxicity and to develop a program for encouraging pollution prevention awareness. Both programs have been developed and represent an ongoing effort to make waste minimization and pollution prevention part of the facility's daily operations.

The GJPO Waste Minimization Program Plan was issued in 1990 (DOE 1990b) and revised in 1992 and 1993 to include a Pollution Prevention Awareness Program and to reflect regulatory changes (DOE 1993d). The overall objectives of the plan are to minimize waste and prevent pollution. Waste reduction is being accomplished through source reduction, composting, material reuse, recycling, and reclamation. Waste that is unavoidably generated is considered for treatment to reduce volume, toxicity, or mobility before storage and disposal.

\subsubsection{Waste Accumulation and Storage}

Satellite Accumulation Areas: The GJPO has established satellite accumulation areas proximate to each of the on-site waste-generating activity locations. The satellite accumulation areas are controlled by the waste generator and inspected monthly by waste management personnel. Accumulated wastes are relocated periodically to either the Waste Accumulation Modules (Buildings 61A, 61B, and 61C) or the Hazardous and Mixed Waste Storage Unit (Building 42) so that the maximum allowable accumulation volume of 55 gallons is not exceeded. As a CESQG, DOE-GJPO is not required to 
establish satellite accumulation areas; however, establishment of these areas is consistent with a small quantity generator status and is deemed a best management practice.

Waste Accumulation Modules: Three Waste Accumulation Modules have been operational since June 1994 as separate accumulation areas for hazardous, low-level, and mixed wastes. Each module is a turnkey structure (approximately 2.5 meters by 2.5 meters by 7 meters) specifically constructed for the accumulation of hazardous wastes. Each has a fire alarm and fire suppression system, an intrinsically safe heating unit, a portable eye wash, and secondary containment in the event of a spill. A standalone emergency shower station is located adjacent to the modules. Waste management personnel conduct routine inspections of the modules. The accumulation of wastes in the modules allows for physical separation of wastes and provides a staging area from which wastes can be prepared for off-site shipment.

Hazardous and Mixed Waste Storage Unit: The Hazardous and Mixed Waste Storage Unit is a RCRA interim-status waste storage area. It is a steel-framed, sheet metal structure secured to a concrete slab foundation. A concrete curb encircles the perimeter of the building and is coated with a chemical-resistant epoxy. Storage cabinets for flammable wastes are used to segregate hazardous wastes by compatibility group within the curbed area. The building is equipped with a fire extinguisher, passive ventilation system, telephone, eye wash station, spill cleanup kit, and an intrinsically safe heating system. Waste management personnel conduct weekly inspections of the storage unit. In addition, the Industrial Safety Engineer conducts periodic inspections of the building to evaluate flammable and combustible loading and the adequacy of the building's fire protection system and equipment.

\subsubsection{Waste Transportation and Disposal}

Qualified waste management personnel conduct on-site transfers of hazardous, low-level, mixed low-level, and PCB wastes in accordance with Procedure 7.4, "On-Site Waste Transfer," Environmental Senvices Desk Instructions (Rust Geotech 1994b). Prior to transferring waste containers, radioactive contamination surveys are performed on each container originating from RMMAs to ensure the absence of external contamination. These procedures satisfy the requirements of DOE Order 5480.3, Safety Requirements for the Packaging and Transportation of Hazardous Materials, Hazardous Substances, and Hazardous Wastes.

DOE-GJPO uses commercial transportation services to dispose of hazardous, low-level, mixed low-level, and PCB wastes at DOE-owned facilities or at commercial facilities permitted by EPA or the states. Approximately 500 kilograms (1,100 pounds) of hazardous and PCB wastes are shipped approximately twice a year. Transportation routes vary depending on the commercial transportation service and destination(s) of the shipment. All waste packagings and shipments comply with U.S. Department of Transportation regulations. Shipment of hazardous, low-level, mixed low-level, and PCB wastes from the GJPO is conducted in accordance with Procedure 5.5, "Shipment of 
Hazardous Waste," of the Stores, Property, and Transportation Desktop Manual (Rust Geotech 1994g).

In accordance with the GJPORAP Record of Decision (DOE 1990a), UMT wastes removed from the facility are transported to the UMTRA Cheney Disposal Cell by an approved subcontractor (see Section 3.1.4). Some UMT wastes (such as contaminated equipment, laboratory instruments, light fixtures, test pits, and calibration pads) may be transported to an approved commercial facility. The 47 cubic meters of PCB-UMT waste will be disposed of at the UMTRA Cheney Disposal Cell or other facility following approval by regulators.

Low-level wastes are disposed of at the DOE Nevada Test Site or at a commercial treatment, storage, and disposal facility that is licensed to receive these wastes. DOE requires that a 5820.2A exemption package be processed for low-level wastes disposed of at non-DOE facilities. This exemption states that the radioactive component of the waste will not be returned to DOE, as stipulated by DOE Order 5820.2A; instead, the radioactive component will be managed in compliance with the requirements of the commercial facility's radioactive license.

Mixed UMT wastes generated by GJPORAP are currently stored on the facility. Pending stabilization of the hazardous component of the waste, they will be disposed of at the UMTRA Cheney Disposal Cell. Mixed low-level wastes are either treated on site through ongoing treatability studies or are shipped off site to a permitted commercial facility.

Asbestos waste removed from the GJPO facility is disposed of at the State-approved Mesa County landfill by qualified on-site personnel or licensed subcontractors. If asbestos waste is radiologically contaminated, it is properly disposed of at the UMTRA Cheney Disposal Cell.

Solid, nonhazardous waste is disposed of at the Mesa County landfill by the city of Grand Junction or collected for off-site recycling by a subcontractor.

\subsubsection{Mixed-Waste Treatment Program}

The Mixed-Waste Treatment Program at the GJPO was initiated in 1994 in response to the Federal Facilities Compliance Act of 1992. The act directs DOE facilities to develop technologies and capacities for treating mixed wastes that are generated or stored on the facilities. DOE-GJPO has prepared the GJPO Proposed Site Treatment Plan (DOE 1995f), which describes the methods that will be used to treat on-site mixed wastes.

As part of the Mixed-Waste Treatment Program, on-site treatability studies using benchand/or pilot-scale treatment technologies are conducted. Two pilot-scale technologies-evaporative oxidation and thermal desorption-are currently under 
evaluation to treat mixed wastes, and bench-scale stabilization/solidification studies are being conducted. Studies using the pilot units will determine the effectiveness or success of both the treatment processes so that larger scale units can be designed and used at DOE sites. DOE-GJPO presently receives mixed wastes from other DOE sites for use in the mixed-waste treatment studies. Received wastes meet the quantity limitations imposed by 40 CFR Section 261.4 (less than 10,000 kilograms total of "contaminated media") for treatability study samples and are stored in Waste Accumulation Module $61 \mathrm{~B}$ until treatment. After treatment, the residues generated by the treatment process are returned to the originator. Personal protective equipment used during the studies are disposed of at permitted commercial facilities.

The pilot treatability study units are located in Building 7 in a RMMA controlled-access area. During operation of the units, an air-handling system maintains a negative pressure within the room to prevent escape of particles or gases. A containment dike is present around the units to retain wastes in the unlikely event of a spill. The benchscale stabilization/solidification studies also are conducted in Building 7.

Evaporative Oxidation: Evaporative oxidation is a process designed to treat aqueous waste streams containing volatile organic and inorganic compounds and nonvolatile, dissolved, inorganic contaminants, such as heavy metals and radionuclides. The pilotscale unit can process approximately 6 liters (1.5 gallons) of aqueous waste per hour. By combining evaporation and vapor catalytic oxidation, the process concentrates the nonvolatile contaminants into a thick liquor or slurry and destroys the volatile compounds.

Thermal Desorption: Thermal desorption is a low-temperature separation process that evaporates or volatilizes organic contaminants from soils, sludges, and other types of solid substances or wastes. The pilot-scale unit processes approximately 45 kilograms (100 pounds) of wet soil per batch. It operates by heating the contaminated material in a nitrogen atmosphere, in which nitrogen serves as an inert carrier gas for the volatilized organics.

Stabilization/Solidification: In these bench-scale studies, chemicals are added to mixedwaste streams to neutralize, stabilize, or solidify the hazardous component(s). The primary chemicals added to the waste stream are Portland cement, water, and/or a reducing agent.

In addition to the on-site treatability studies, a Sort, Survey, and Decontamination Project is conducted under the Mixed-Waste Treatment Program. The main objective of this project is to develop and implement a field unit that will assist DOE Albuquerque Operations Office sites with sorting, surveying, and surface-decontaminating suspect radioactive waste to allow release of the waste to commercial facilities. This project has allowed DOE-GJPO to substantially reduce its mixed-waste inventory. 


\subsubsection{Environmental Monitoring}

Environmental monitoring was begun on the facility in 1979 to characterize the type and extent of contamination from early site operations. When GJPORAP remediation commenced, the monitoring objectives shifted to verifying compliance with Federal, State, and DOE standards and to detecting changes resulting from remedial action on the site. Presently, monitoring of groundwater, surface water, wetland areas, sewer effluent, storm water, meteorology, and the Sample Plant Baghouse is conducted on a routine basis. (Monitoring of radon, air particulates, and gamma radiation was conducted regularly until July 1,1994 , but was discontinued when the removal of exterior UMT waste was completed). Strategies for conducting environmental monitoring are described in the Environmental Monitoring Plan (DOE 1995e) and Sampling and Analysis Plan for Environmental Monitoring (Rust Geotech 1994c). Data collected from monitoring activities are summarized and reported annually in Site Environmental Reports in accordance with DOE Order 5400.1, General Environmental Protection Program.

\subsubsection{Groundwater}

Personnel collect groundwater samples every 9 months from 12 wells representing upgradient, on-site, and downgradient conditions within the underlying alluvial aquifer. Typically, concentrations of arsenic, molybdenum, nitrate, selenium, total dissolved solids, uranium, and gross alpha exceed groundwater quality standards. These constituents are believed to be present in the groundwater from the historic leaching of on-site uranium mill tailings. Groundwater modeling of the alluvial aquifer predicts that the groundwater will be cleaned (by means of natural flushing) to below applicable standards within 50 to 80 years after exterior UMT waste is removed. Removal of all known exterior UMT waste was completed on July 1, 1994 (DOE 1995b).

ORNL installed 10 monitoring wells along the north and west perimeters of the GJPO facility in the fall of 1994 as part of an independent verification program associated with GJPORAP. Samples collected from these wells are analyzed for priority pollutant metals, uranium, molybdenum, and vanadium. Quarterly sampling of the wells will be terminated after collection of data for approximately 2 years.

\subsubsection{Surface Water}

Surface-water samples are obtained every 9 months from the North Pond, South Pond, wetland area west of the North Pond, and four locations on the Gunnison River (one sample upstream of, two samples adjacent to, and one sample downstream of the GJPO facility). Water in the North Pond, South Pond, and wetland area is contaminated with the same constituents as the groundwater because these water sources are recharged by the shallow alluvial aquifer. Water quality will improve over time by means of natural flushing. 
Fifteen years of water-quality monitoring of the Gunnison River has indicated that, with one exception, neither discharges from the contaminated alluvial aquifer nor operations at the GJPO facility have affected water quality within the river. The one exception has been uranium discharges from the alluvial aquifer. During some sampling events, uranium concentrations have been measured at higher concentrations at the downstream sampling location than at the upstream or adjacent sampling locations. However, the State water-quality standard for uranium $(40 \mathrm{pCi} / \mathrm{L})$ has never been exceeded at any of the locations. In March 1994, for example, the concentration of uranium at the upstream sampling location was $6.6 \mathrm{pCi} / \mathrm{L}$, the concentration at the adjacent sampling location was $8.9 \mathrm{pCi} / \mathrm{L}$, and the concentration at the downstream sampling location was $14.0 \mathrm{pCi} / \mathrm{L}$. The river will continue to be monitored to determine if changes in water quality occur as a result of the removal of exterior UMT waste.

\subsubsection{Wetland Areas}

In 1989, DOE-GJPO was granted a 404 permit by the U.S. Army Corps of Engineers (COE) to remove UMT waste from wetland and riparian areas on the GJPO facility. In 1994 and 1995, the areas were reconstructed and revegetated in accordance with the 404 permit requirements. Approximately 0.6 hectare $(1.45$ acres) of wetland habitat and 1.3 hectares ( 3.11 acres) of riparian habitat were restored. The permit requires DOE to evaluate the effectiveness of the restoration over a 5-year period.

Monitoring of the restored areas began in August 1995 and consisted of (1) determining the status of wetland plant species establishment; (2) measuring the drip-line diameter and height of a representative random sample of tree and shrub transplants;

(3) determining the percent survival rate of the transplants; and (4) determining the percent ground cover of grasses. Results of the monitoring are summarized in annual monitoring reports (DOE 1995c) to the COE.

\subsubsection{Sewer Effluent}

GJPO sewer effluent is directed to a publicly owned treatment works in accordance with an Industrial Pretreatment Permit issued by the city of Grand Junction. As required by the permit, sampling of sewer effluent is conducted quarterly for biochemical oxygen demand, oil and grease, PCBs, silver, total dissolved solids, total suspended solids, and ammonia. A monthly flow-proportioned, composite sample is collected and analyzed for gross alpha and gross beta, and a weekly grab sample is collected for an instantaneous measurement of $\mathrm{pH}$ and temperature. Samples are collected downstream of all GJPO facilities at a manhole located east of Building 19 in the employee parking lot.

Since monitoring began in 1989 , concentrations of measured constituents in the samples have not exceeded threshold limits, with the following exceptions: biochemical oxygen demand in February 1989 and December 1992; total suspended solids in December 1992; and $\mathrm{pH}$ in February 1993. After each measurement in which threshold limits were 
exceeded, the cause of the high concentration was discovered and procedures were implemented to prevent reoccurrences. Subsequently, the effluent was resampled to ensure that concentrations were within limits.

\subsubsection{Storm Water}

Storm-water effluent at the GJPO consists of runoff from administrative buildings, facility parking lots, and other paved areas. Runoff from these areas is directed into a storm-drain collection network and discharged to the South Pond. Currently, the GJPO is not required to have an NPDES storm-water discharge permit. However, storm-water effluent is monitored annually as a best management practice. Sampling began in fall 1994 for constituents recommended by EPA: biochemical oxygen demand; chemical oxygen demand, nitrate + nitrite as nitrogen, $\mathrm{pH}$, total Kjeldahl nitrogen, total phosphorus, total suspended solids, radium-226, and total uranium. No threshold limits are associated with these constituents.

\subsubsection{Meteorology}

Meteorological monitoring is conducted at the facility to characterize atmospheric transport and diffusion conditions so that the impacts of airborne releases on public health and safety can be assessed. The meteorological station, which is located west of the North Pond, is erected on a 10-meter (33-foot) tower and monitors temperature, relative humidity, wind speed, wind direction, and barometric pressure. Measurements are taken every 10 seconds, averaged at 1 -hour intervals, and stored by a data logger and associated software.

\subsubsection{Baghouse}

The Baghouse (Building 62) exhaust stream is sampled continuously whenever the Baghouse is in operation. Monitoring filters are collected and analyzed on a monthly basis. Data generated by the sampling is used to estimate the off-site radiological dose to members of the public that results from Baghouse and other radiological emissions on the facility.

\subsubsection{Workplace Monitoring}

Radiological monitoring is conducted routinely at the GJPO facility to (1) characterize workplace conditions, (2) verify the effectiveness of physical design features and engineering and administrative controls for containing radioactive material and reducing radiation exposure, (3) identify areas requiring postings, (4) demonstrate compliance with regulations in 10 CFR Part 835, "Occupational Radiation Protection," (5) detect changes in radiological conditions, and (6) detect the gradual buildup of radioactive material in 
the workplace. Stationary and/or portable instruments are used to conduct radiation exposure and contamination surveys and to monitor airborne radioactivity. A detailed description of workplace monitoring procedures is in Chapter 5 of the Health and Safety Manual, Volume 2 (Rust Geotech 1995b).

\subsubsection{Radiation Exposure Surveys}

Radiation exposure surveys include the measurement of dose rate (1) for a general area, (2) at a distance of 30 centimeters (1 foot) from a source or surface of interest, and (3) at the contact with potential sources of radiation when hands-on work may be conducted. Surveys are conducted whenever personnel may be exposed to small, intense beams of radiation, such as those generated by shielded $\mathrm{x}$-ray devices. Routine surveys also are conducted at the following frequencies and locations:

- Daily, in office space located in Radiological Buffer Areas (established for the control of contamination) where potential exists for external radiation exposure.

- Weekly, in routinely occupied Radiological Buffer Areas and Radiation Areas.

- Upon initial entry, weekly (during continuing operations), and when levels are expected to change in High Radiation Areas.

- Weekly, during operation of HEPA-filtered ventilation units.

- Weekly, at temporary Radiation Area boundaries to ensure that radiation areas do not extend beyond posted boundaries.

- Monthly, or upon entry if entries are less frequent than monthly, for Radioactive Material Areas.

- Monthly, at potentially contaminated ducts, piping, and hoses that are being used outside radiological facilities.

\subsubsection{Contamination Surveys}

Routine contamination surveys are conducted in Radiological Buffer Areas and other areas where contamination could be spread. Surveys are conducted at the following frequencies and locations:

- Prior to transfer of equipment and material from one Radiological Buffer Area to another. 
- Prior to transfer of equipment and material from highly contaminated areas within Radiological Buffer Areas, unless precautions such as bagging or wrapping are taken before transfer.

- Daily, at contamination area control points, change areas, or step-off pads, or during each shift in high-use situations.

- Daily, in office space located in Radiological Buffer Areas.

- Daily, in lunch rooms or eating areas near Radiological Buffer Areas.

- Weekly, in routinely occupied Radiological Buffer Areas.

- Weekly, or upon entry if entries are less frequent, in areas where radioactive materials are handled or stored.

- Weekly, or upon entry if entries are less frequent, where contamination boundaries or postings are located.

- During initial entry into a known or suspected contamination area, periodically during work, at completion of job, or as specified in a Radiological Work Permit.

- After a leak or spill of radioactive materials.

\subsubsection{Airborne Radioactivity Monitoring}

Airborne radioactivity monitoring is conducted in situations where airborne radioactivity levels may fluctuate and when early detection of airborne radioactivity may prevent or minimize inhalation of radioactivity by personnel. Various types of air monitoring equipment may be used, depending on the specific job being monitored. Types of equipment are specified in Chapter 5 of the Health and Safety Manual, Volume 2 (Rust Geotech 1995b).

\subsection{Proposed Action Alternative}

The Proposed Action Alternative includes activities under the No Action Alternative as well as activities associated with the anticipated expansion and upgrade of GJPO facilities and operations. This alternative would continue facility maintenance and operations, laboratory activities, GJPO tenant operations, environmental restoration activities, other GJPO operations, research and development, waste management, environmental monitoring, and workplace monitoring. In addition, GJPO would continue to use its project management, engineering, analytical, and scientific capabilities to provide comprehensive support to DOE environmental activities. 
In anticipation of increased support requirements under the Proposed Action Alternative, operations at the GJPO facility would be expanded to fulfill the DOE mission. The need for environmental cleanup and project management support across the DOE complex would increase requirements for: environmental restoration, waste management, research and development, engineering and geoscience capability, and laboratory capacity at the GJPO. Providing this increased capability would involve the renovation of existing facilities and construction of new facilities. The planned activities are summarized in Table 4 and described in the following sections. Figure 3 shows the location of the proposed buildings.

\section{Table 4. Summary of Proposed Construction Activities Under the} Proposed Action Alternative

\begin{tabular}{||l|l||}
\hline \begin{tabular}{|l||}
\hline Fiscal \\
Year
\end{tabular} & \multicolumn{1}{c|}{ Proposed Construction Activity } \\
\hline \hline 1997 & $\begin{array}{l}\text { Three Modular Buildings (new buildings) } \\
\text { Radiochemistry Preparation Laboratory (upgrade within Building 20) } \\
\text { Organic Extraction Laboratory (upgrade within Building 20) } \\
\text { Health Training Facility (new building) } \\
\text { Maintenance and Testing Facility (new building) }\end{array}$ \\
\hline 1998 & $\begin{array}{l}\text { Two Modular Buildings (new buildings) } \\
\text { Emergency Operations Center (replaces Building 19) } \\
\text { Environmentally Controlled Volatile Organic Measurement Laboratory (upgrade within } \\
\text { Building 20) } \\
\text { Kitchen Addition (addition to Building 46) }\end{array}$ \\
\hline 1999 & $\begin{array}{l}\text { Three Modular Buildings (new buildings) } \\
\text { New Irrigation System } \\
\text { Office Building (new building-replaces Buildings 57A-E) } \\
\text { Semivolatile Organic Laboratory (upgrade within Building 20) }\end{array}$ \\
\hline 2000 & $\begin{array}{l}\text { Northwest Office Complex (new building-replaces Buildings 2, 18, 54, and 810) } \\
\text { Medical Facility (new building) }\end{array}$ \\
\hline 2001 & Site Management Offices and Shops (new building) \\
\hline 2002 & Environmental Restoration Field Equipment Facility (new building) \\
\hline 2007 & New Analytical Chemistry Laboratory (new building) \\
\hline
\end{tabular}

\subsubsection{Facility Maintenance and Operations}

Because the proposed construction represents a limited expansion or replacement of existing facilities, the demand for utilities such as electricity, heating, air conditioning, and water are not expected to increase. A new irrigation system using nonpotable water would be installed in FY 1999 to replace the current system, which uses treated city water. To install new lines, trenches would be dug through lawn and paved areas, lines would be laid, and the removed material would be replaced. 
Building renovations and new construction would be performed by subcontracted construction companies in accordance with 29 CFR Part 1910, "Occupational Safety and Health Standards;" and 29 CFR Part 1926, "Safety and Health Regulations for Construction." Nonregulated wastes generated from renovation and construction activities would be recycled or disposed of at the Mesa County landfill. Regulated leadbased paint that is removed from buildings would be treated as hazardous waste and shipped to a commercial facility for treatment and disposal. If UMT waste were discovered during building renovation or construction, it would be removed and transported to the UMTRA Cheney Disposal Cell.

During periods of renovation and construction, modular buildings would be erected on the facility to provide temporary office space for employees. Approximately eight modular buildings would be erected during FYs 1997-1999.

In FY 1998, a site security Emergency Operations Center would be built to replace Building 19. The current room (Room 202 of Building 810) used for an Emergency Operations Center is not dedicated to emergency operations, which slows the response time in emergency situations. The new building would be dedicated as an Emergency Operations Center and would provide improved visibility to the single access road to the GJPO. In addition, a new office building is proposed for construction in FY 1999 to replace leased Buildings 57A-E.

From FY 2000 through FY 2002, several new buildings would be constructed to replace old buildings or storage lost from demolition under GJPORAP. The Northwest Office Complex would replace Buildings 2, 18, 54, and 810 and would provide office space for approximately 150 employees. New site management offices and work shops would be built in FY 2001 to replace the 19,000 square feet of storage space lost when Building 31 was demolished in 1992. Once maintenance and craft shops are moved to the new building, Building 28 would be available for shipping, receiving, and storage. A new Environmental Restoration Field Equipment Facility would be constructed in FY 2002 to provide storage and operation areas for various field instruments and equipment.

\subsubsection{Laboratories}

Future upgrades of the Analytical Laboratory would be aimed at enhancing the site's capabilities to meet DOE's need for additional analytical laboratory facilities. In FY 1997, current office space in Building 20 would be modified for use as a Radiochemistry Preparation Laboratory and an Organic Extraction Laboratory. In FYs 1998 and 1999, laboratory areas within Building 20 would be upgraded to include an Environmentally Controlled Volatile Organic Measurement Laboratory and a Semivolatile Organic Laboratory. A new, two-story, Analytical Chemistry Laboratory would be constructed in FY 2007.

Future waste streams generated by the Analytical Laboratory are expected to be similar to those that are presently generated (see Section 3.1.2.1). 


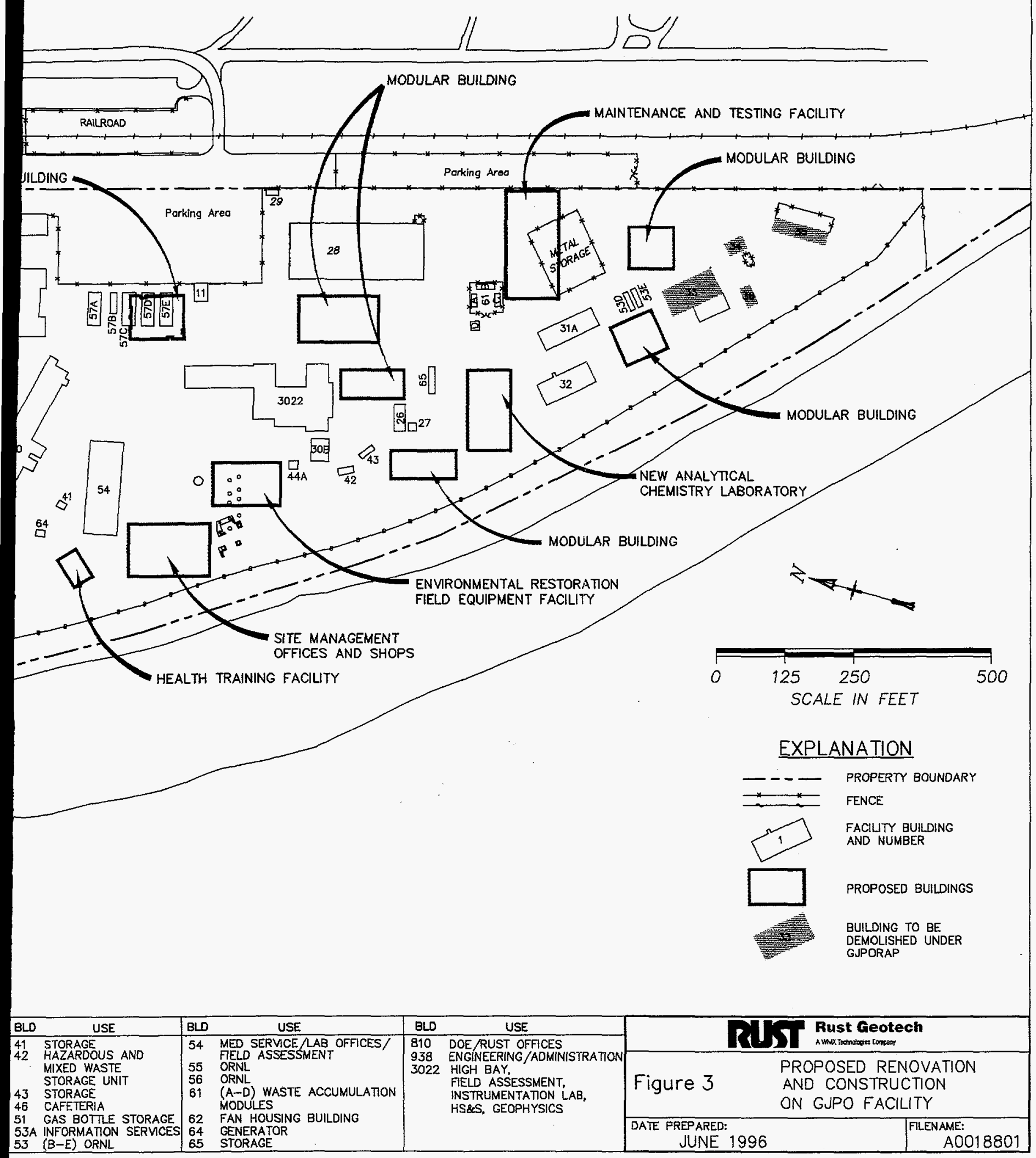




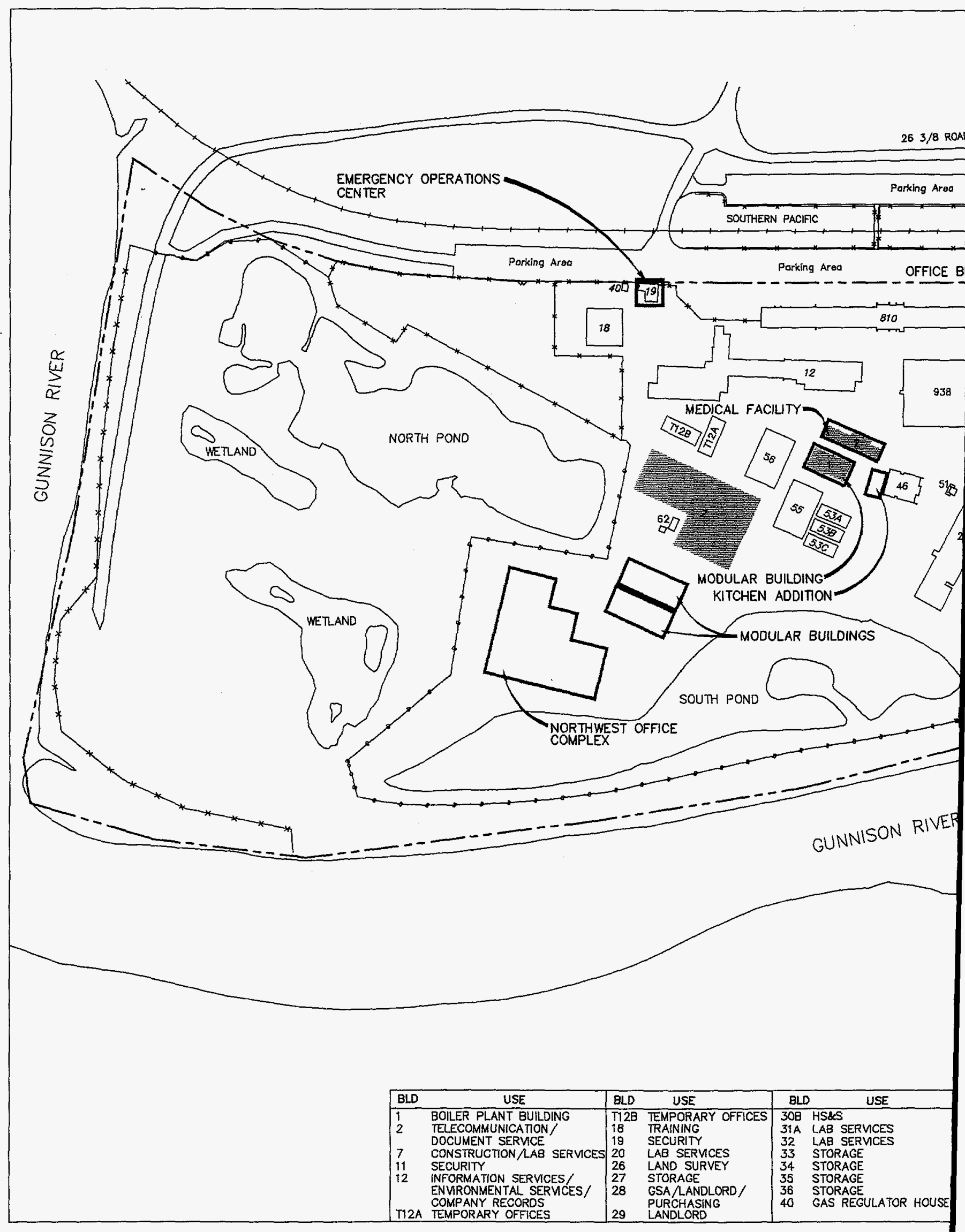


page left

intentionally blank 



\subsubsection{Environmental Restoration Activities}

Remedial actions under GJPORAP, encompassing removal of UMT waste in on-site buildings, would continue in the future. Table 5 lists the buildings proposed for decontamination and demolition.

Table 5. Proposed Remedial Actions under GJPORAP

\begin{tabular}{||l|l||}
\hline \multicolumn{1}{|c|}{ Building } & \multicolumn{1}{c|}{ Remedial Action } \\
\hline \hline Building 1 & Demolition \\
\hline Building 34 & Demolition \\
\hline Building 35 & Demolition \\
\hline Building 36 & Demolition \\
\hline Building 46 & Demolition of floor; tailings removal from beneath building \\
\hline Building 810 & $\begin{array}{l}\text { Assessment of contamination on soil surface; decontamination } \\
\text { if necessary }\end{array}$ \\
\hline Building 31-A & Decontamination of sump \\
\hline Building 33 & Demolition \\
\hline Building 938 & Decontamination of attic areas \\
\hline Building 2 & Decontamination or demolition \\
\hline Building 7 & Demolition \\
\hline Building 20 & Decontamination \\
\hline
\end{tabular}

The buildings proposed for decontamination and demolition are constructed of a variety of materials. Approximately half are steel-framed structures with corrugated metal siding and concrete floors. They presently are used almost exclusively for warehouses and storage buildings. The other half are constructed of concrete blocks, clay tiles, or wood frames. These buildings generally are used for office space or laboratories.

Roofing materials typically are either asphalt shingles over wood sheathing or steel panels over steel trusses. Many of the roofs have had urethane foam installed on their upper surfaces for insulation. Siding is typically wood or metal. Interior partitions generally are drywall installed over wood studs. Most of the floors are concrete, although some are wood with crawl spaces underneath. At least one building has asbestos-cement siding and roofing, and it is not uncommon to find obsolete structures or remnant utility systems abandoned in place or concealed by other construction. The contamination that has been identified in these buildings typically consists of surface contamination, general residue and scale in drains, and small deposits of contaminated soil beneath concrete floors or crawl spaces. 
Future actions under GJPORAP are expected to be similar to past and present-day actions described in Section 3.1.4. Approximately 9,100 cubic meters (11,930 cubic yards) of UMT waste would be generated from building decontamination and demolition. In addition, approximately 2,000 cubic meters (2,600 cubic yards) would be generated as solid waste, and approximately 750 cubic meters (1,000 cubic yards) would be generated as salvageable materials. Transportation of these wastes off site would be conducted in the same manner as at present.

Completion of GJPORAP activities would occur by fiscal year 2000 and would be documented in Closeout Reports for each building. These reports would include a brief history of the decontaminated or demolished building, a description of the contamination and how it was removed, results of the verification survey, and the specific release criteria used for the building. Long-term surveillance and maintenance (LTSM) activities would commence once GJPORAP activities were completed. Under LTSM, buildings would be inspected for roof leaks and structural integrity on a regular basis. In addition, groundwater and surface water at and near the facility would be monitored on a 9-month schedule to detect changes in water quality resulting from past remedial action (see Section 3.1.8, Environmental Monitoring).

\subsubsection{Other GJPO Operations}

Two of the buildings proposed for construction under this alternative would upgrade the current on-site medical facilities. A Health Training Facility would be constructed in FY 1997 and would provide areas for first-aid and cardiopulmonary resuscitation training, fitness development, and general employee health training programs. In FY 2000, a new Medical Facility would be constructed to replace the current offices in Building 54. The new building would provide space for examining rooms, a treatment room, a reception area, and offices for five staff members, including a physician. Future waste streams are expected to be similar to those currently generated (see Section 3.1.5.1).

Capabilities of the on-site food service would be enhanced by a kitchen addition planned for FY 1998. The addition would expand the present food preparation and storage areas and eating area. Future waste streams from this facility are expected to be similar to those currently generated (see Section 3.1.5.4).

\subsubsection{Research and Development}

GJPO's Program Support Research and Development program and Technology Development Program would continue in the future. Table 6 summarizes the projects proposed for FY 1996 under both programs. Future waste streams generated as a result of the programs are expected to be similar to those currently generated (see Section 3.1.6). 
Table 6. Summany of GJPO Research and Development Projects for FY 1996

\begin{tabular}{|c|c|}
\hline Program Support Research and Development & Technology Development Program \\
\hline $\begin{array}{l}\text { Reconstruction of Contaminant Burial Histories in } \\
\text { Montezuma Creek, Monticello, Utah } \\
\text { Mineralogic Residence of Contaminants in } \\
\text { Aquifers } \\
\text { Feasibility of Detecting and Reconstructing } \\
\text { Shallow Aquifer Plume Migration Using } \\
\text { Phreatophyte Dendrochemistry } \\
\text { Natural and Archaeological Analogs of the Long- } \\
\text { Term Performance of Rock Covers for Shallow } \\
\text { Land Burial } \\
\text { Free Fluid Identification by Nuclear Magnetic } \\
\text { Resonance and Time Domain Electromagnetic } \\
\text { Sounding } \\
\text { Publication of Data Regarding the Long-Term } \\
\text { Performance of an Amorphous Ferric } \\
\text { Oxyhydroxide Chemical Barrier } \\
\text { Medium-Frequency Electromagnetic Surveys } \\
\text { Geophysics at Industrial and Urban Sites } \\
\text { High-Resolution Techniques for Tracing Very } \\
\text { Slow Airflow } \\
\text { Evaluation of 3-Element Magnetic Gradiometer } \\
\text { Pipe-Scale Gauge Project } \\
\text { GJPO Environmental Problem Solving Process } \\
\text { Quality Management Program Consultation and } \\
\text { Implementation } \\
\text { Long-Term Site Monitoring by Electrical Methods } \\
\text { Application of Spectral Analysis Surface Waves } \\
\text { Seismic Techniques to Environmental } \\
\text { Restoration Projects } \\
\text { Dependence of Indoor Radon Concentration on } \\
\text { Local Topography } \\
\text { Demonstration of Simultaneous Recording of } \\
\text { Geophysical Data Sets and GPS Survey } \\
\text { Coordinates for GJPO and Vicinity Operations } \\
\text { Geophysical Methods for Nonintrusive Monitoring } \\
\text { of Groundwater and Contaminant Plume } \\
\text { Movement through the Groundwater Regime } \\
\text { University of Waterloo DNAPL Site Diagnosis and } \\
\text { Remediation Short Course } \\
\text { Water Balance Modeling of Natural and } \\
\text { Engineered Soil Profiles: Comparison of HELP, } \\
\text { UNSAT-H, and SWIM Simulations with Small } \\
\text { Lysimeter Field Data } \\
\text { Upgrade of Nuclear Modeling Capabilities } \\
\text { Mear }\end{array}$ & $\begin{array}{l}\text { Monitoring Information Management Systems } \\
\text { Sample Management Office Support } \\
\text { Performance Evaluation Sample Program } \\
\text { DOE Albuquerque Operations Office Technical } \\
\text { Support } \\
\text { Fernald Radon Monitoring and Mitigation Systems } \\
\text { Rabbit Valley Geophysical Performance } \\
\text { Evaluation Range } \\
\text { Three-Dimensional Site Characterization Using } \\
\text { Broadband Electromagnetics } \\
\text { Site Characterization and Object Location Using a } \\
\text { Tensor Magnetic Gradiometer } \\
\text { Analysis of Grout or Frozen-Ground Barrier } \\
\text { Integrity by Crosshole Acoustic Imaging } \\
\text { 3D/3C Reflection Seismic }\end{array}$ \\
\hline
\end{tabular}




\subsubsection{Waste Management}

In the future, the GJPO's CESQG status would be maintained unless GJPO generated more than 100 kilograms of hazardous and mixed waste in 1 month. Potential increases in laboratory capacity and capability under the Proposed Action Alternative could result in the elevation of the GJPO's status to an SQG. The additional hazardous and mixed low-level wastes generated by the laboratory would be stabilized on site approximately twice a year in accordance with SQG allowances (i.e., the wastes would be stabilized within 180 days of generation). On-site stabilization of these wastes would involve the addition of cement and water to the waste to render the hazardous component nonhazardous; hence, the waste would no longer be considered a RCRA-regulated waste. The stabilized wastes would then be disposed of at the Mesa County landfill or at an approved low-level waste disposal facility, as appropriate. The volumes of regulated waste transported off site and stored on site are expected to remain at current levels.

Construction of a Maintenance and Testing Facility is proposed for FY 1997. This facility would serve a number of purposes. First, it would provide a central receiving area for wastes where waste shipments would be inspected for proper packaging and labeling and then directed to the appropriate storage module. Second, it would provide receiving, maintenance, and storage areas for the mobile treatment units associated with the Mixed-Waste Treatment Program. Further NEPA review might be required for this facility.

\subsection{Shutdown Alternative}

Under the Shutdown Alternative, current operations at the GJPO facility would be discontinued. Programmatic responsibilities presently maintained by the GJPO would be discontinued or transferred to other DOE offices. Up to 680 people would lose their jobs at the facility. Although this alternative would prohibit the GJPO from supporting DOE's cleanup goals, discussion of it allows for an analysis of a full range of alternatives.

Before shutdown of the facility, another NEPA document would be prepared that would compare alternatives for future land uses. Regardless of the future land use, DOE would be committed to completing GJPORAP. Activities that would be conducted under GJPORAP are described in Section 3.2.3. After the completion of GJPORAP, only LTSM activities would be conducted on the facility. LTSM activities would consist of security fence maintenance, building inspections (for roof leaks and structural integrity), and groundwater and surface-water monitoring. This latter activity, which is required by the GJPORAP Record of Decision (DOE 1990a), would be conducted for 50 to 80 years by subcontracted personnel from another DOE office. LTSM activities would cease once restoration of groundwater quality was verified. 


\subsection{Affected Environment}

This section, which characterizes the existing environment at the GJPO facility, also serves as a description of the No Action Alternative. Only those elements of the environment that may be affected by the alternatives are discussed. Elements that are not affected, such as land use, visual resources, cultural resources, geology, mineral resources, and recreation, are not discussed in this document.

\subsection{Transportation}

Daily traffic to and from the GJPO facility consists primarily of $600-660$ vehicles driven by employees and about 50 service vehicles driven by subcontractors or delivery personnel. Employee vehicles are parked in marked parking lots on the east side of the facility outside the security fence. Service vehicles enter and exit the facility at the vehicle gate. On the facility itself, 29 electric and gas-powered carts and several gaspowered vehicles are available for transporting people and supplies.

When buildings are decontaminated or demolished under GJPORAP, three to four tandem dump trucks are used to transport waste materials to the UMTRA Cheney Disposal Cell or Mesa County landfill. Each truck makes a maximum of five trips a day and hauls a maximum of 12 cubic yards (roughly 17 tons) of material per trip.

About twice a year, approximately 500 kilograms (1,100 pounds) of hazardous, low-level, mixed low-level, and PCB wastes are shipped from the GJPO facility by a subcontracted waste packaging and shipping service. The packaged wastes are transported to one or more commercial waste facilities. All packaging and transportation activities are conducted in accordance with on-site procedures and in compliance with U.S. Department of Transportation regulations.

The only ingress to and egress from the GJPO facility is a two-lane, city-maintained road (B 3/4 Road) about 0.8 kilometer $(0.5$ mile) in length. This road connects the GJPO facility to U.S. Highway 50, one of the major transportation routes through Grand Junction and across southern Colorado. Within the city limits, U.S. Highway 50 has four lanes and numerous traffic lights; outside the city limits, it has two lanes and crosses sparsely populated, desert rangelands. Other major transportation routes in the vicinity of the GJPO are U.S. Interstate 70, which is part of a major east-west transcontinental trucking route; Colorado State Highway 141, which, along with U.S. Highway 50, provides access to the south; and the Southern Pacific Railroad, which borders the east side of the facility.

During FY 1994, three accidents involving a vehicle occurred in the employee parking lots. Damage incurred in all incidents was minor and none involved injury to people (Hurd 1994). On the facility itself, two accidents involving a vehicle occurred in 
FY 1994. Both accidents consisted of backing into objects and resulted only in minor damage; neither were reportable incidents (Hightower 1994).

\subsection{Noise}

Noise on the GJPO facility is generated primarily by renovation, GJPORAP remedial activities, and motorized vehicles. Health, Safety, and Security personnel routinely measure noise levels of on-site activities. Measurements during the last several years indicate that, with a rare exception, noise levels have been well below the action level of 85 decibels (on the A-weighted scale) established by 29 CFR Section 1910.95, "Occupational Safety and Health, Occupational Noise Exposure." In the rare cases where the standard was exceeded, administrative or engineering controls were implemented to reduce noise levels, and a hearing conservation program was developed and conducted.

\subsection{Air Quality}

Two sources of radon emissions and two point sources of radioparticulate emissions occur on the GJPO facility. Radon is emitted from the instrument calibration facilities and radon calibration chambers. Sources of radioparticulate emissions are the Analytical Laboratory and the Baghouse.

The present total release of radon from the facility is about $0.52 \mathrm{Ci} / \mathrm{yr}$ (Price 1994). This amount has no measurable effect on the atmospheric radon concentration at the facility boundary.

The amount of radioparticulate emissions and the dose on nearby persons is calculated annually to determine compliance with DOE Order 5400.5, Radiation Protection of the Public and the Environment, and the National Emission Standards for Hazardous Air Pollutants, Subpart $\mathbf{H}$. Both the DOE order and the Federal standard establish a "maximally exposed individual" dose limit of $10 \mathrm{mrem} / \mathrm{yr}$ for exposure to airborne radioparticulate emissions (excluding radon) from DOE facilities. DOE Order 5400.5 also requires calculation of a collective population dose (dose to residents within an 80-kilometer radius of the facility), which includes a radon source term. Dose modeling is performed using the CAP88-PC computer model.

Results of dose modeling during the last several years indicate that the total radioparticulate dose to the maximally exposed off-site individual is consistently below the DOE and EPA standard of $10 \mathrm{mrem} / \mathrm{yr}$; presently, the dose from the two point sources is about $0.00006 \mathrm{mrem} / \mathrm{yr}$ (Price 1994). The total off-site dose to the public, which includes the radon source term, also is consistently below the DOE dose limit of $100 \mathrm{mrem} / \mathrm{yr}$ above background; the current calculated value is $0.0155 \mathrm{mrem} / \mathrm{yr}$ (excluding background). The collective population dose, for which no standard exists, is estimated at 0.0471 person-rem per year. 
Nonradiological air particulate emissions on the facility are well below the standards established by EPA and the State of Colorado. Acceptable levels of particulate matter 10 micrometers or smaller $\left(\mathrm{PM}_{10}\right)$ are defined under the National Primary and Secondary Ambient Air Quality Standards. $\mathbf{P M}_{10}$ standards specify a maximum annual concentration of 50 micrograms per cubic meter $\left(\mu \mathrm{g} / \mathrm{m}^{3}\right)$ and a maximum 24-hour concentration of $150 \mu \mathrm{g} / \mathrm{m}^{3}$. In 1993 , when mill tailings were being removed from the facility, the maximum annual $\mathbf{P M}_{10}$ concentration was $16.9 \mu \mathrm{g} / \mathrm{m}^{3}$, and the maximum 24-hour concentration was $42.8 \mu \mathrm{g} / \mathrm{m}^{3}$. Because monitoring of $\mathrm{PM}_{10}$ concentrations was terminated in July 1994 when mill tailings removal operations were completed, current concentrations are not known but are presumed to be less than 1993 values.

Other sources of nonradiological pollutants on the facility include the Analytical Laboratory, Petrology Laboratory, Baghouse, and painting activities. The CDPHE granted DOE-GJPO an air emission permit for the Analytical Laboratory; all other sources were exempted from permit requirements because of June 1993 regulation revisions and low-pollutant levels.

\subsection{Soils}

The GJPO facility lies on a bench above the Gunnison River on which approximately 11 meters ( $35 \mathrm{feet}$ ) of alluvial sand and gravels has been deposited. Soils formed in this material range from a few inches to several feet thick. They are classified as fine-loamy, mixed (calcareous), mesic Typic Torrifluvents, which are young, undeveloped soils formed in alluvium. Soil textures range from sandy loam to loam, and soil $\mathrm{pH}$ ranges from 7.9 to 8.4. Prime or unique farmland does not exist on or immediately adjacent to the facility (Spears and Kleven 1978; Currier 1994).

Before remediation began, soils contaminated by radium-226, thorium-230, and uranium covered about 9 hectares ( 23 acres) of the facility, primarily in areas of buried UMT waste. Once an area was remediated and before it was backfilled, both Rust and ORNL verified that it was free of radioactive materials in accordance with criteria established in 40 CFR Part 192, "Health and Environmental Standards for Uranium and Thorium Mill Tailings." By July 1, 1994, all known UMT waste in open-land areas had been removed from the facility.

\subsection{Groundwater}

Three hydrogeologic units of importance underlie the GJPO facility: the unconsolidated alluvial aquifer along the Gunnison River, the Morrison Formation aquitard, and the Entrada Sandstone aquifer. The alluvial aquifer underlying the facility occupies about 22.8 hectares (56.4 acres) of the Gunnison River floodplain; its thickness ranges from 6 to 21 meters ( 20 to 70 feet) but averages between 6 and 8 meters ( 20 and 25 feet). Bounded on the west and north by the river and on the east by the shales and sandstones of the Morrison Formation, the aquifer is open to the south where the alluvium 
continues along the east boundary of the river. Recharge is mainly from fluctuations in the river and, to a much lesser extent, precipitation. Groundwater is discharged into the Gunnison River along the north and west boundaries of the facility. Aquifer pump tests show the hydraulic conductivity of the alluvium to be approximately 9 meters ( 30 feet) per day, and the specific yield to be on the order of 0.05 . Currently, the alluvial groundwater is not used for any purpose.

Underlying the alluvial aquifer is the Morrison Formation, which, in the Grand Junction area, comprises the Brushy Basin and Salt Wash Members. The formation is composed primarily of red, green, and gray shale, although minor lenticular sandstones are present in the upper Brushy Basin, and increasing sandstone facies occur in the Salt Wash. The Morrison serves as an aquitard beneath the facility, as it inhibits downward groundwater flow and prevents communication between the overlying alluvial aquifer and the underlying Entrada Sandstone aquifer.

The historical presence of uranium mill tailings on the facility resulted in the contamination of alluvial groundwater by constituents associated with the tailingsmainly uranium, arsenic, selenium, and molybdenum. Since 1980, water-quality data have been collected from as many as 72 monitoring wells installed on and adjacent to the facility. Today, many of these wells have been abandoned, and only 22 of the wells continue to be routinely monitored. Table 7 lists the maximum concentrations of selected constituents from the 1994 and historical groundwater monitoring programs and compares them to Federal and State standards. Of the constituents measured in 1994, concentrations of arsenic, molybdenum, nitrate, selenium, total dissolved solids, uranium-234, uranium-238, and gross alpha exceeded standards. Groundwater modeling of the alluvial aquifer predicts that the groundwater will be cleaned to below standards within 50 to 80 years after removal of the exterior UMT waste (DOE 1989), which was completed by July $1,1994$.

\subsection{Surface Water}

Surface-water sources at or near the GJPO facility include the North Pond, South Pond, wetland areas adjacent to the North Pond, and Gunnison River, all of which contain water perennially. The North and South Ponds and the wetland areas are located on the GJPO facility, and the Gunnison River is contiguous to the facility's western and northern boundaries. Water from the ponds is not used for any purpose, and there is no known consumptive use of the Gunnison River between the facility and the confluence with the Colorado River. All domestic surface-water sources for the city of Grand Junction are upgradient of the GJPO facility.

Since 1980, surface-water sources on and near the GJPO facility have been monitored regularly for water-quality parameters. Water quality of the ponds and wetland areas is similar to that of the alluvial groundwater because these surface-water sources are recharged by the groundwater. Like the groundwater, they contain elevated concentrations of constituents associated with uranium mill tailings-arsenic, manganese, 


\section{Table 7. Comparison of Federal and State of Colorado ${ }^{b}$ Groundwater Quality Standards to 1994 and Historical Maximum Concentrations in the Alluvial Aquifer}

\begin{tabular}{|c|c|c|c|c|c|c|c|c|}
\hline \multirow{2}{*}{ Constituent } & \multirow{2}{*}{\multicolumn{2}{|c|}{$\begin{array}{c}\text { Federal/State } \\
\text { Standard }\end{array}$}} & \multicolumn{3}{|c|}{1994 Maximund } & \multicolumn{3}{|c|}{ Historical Maximnnd,e } \\
\hline & & & $\begin{array}{c}\text { Up- } \\
\text { gradient }\end{array}$ & $\begin{array}{l}\text { On } \\
\text { Site }\end{array}$ & $\begin{array}{c}\text { Down- } \\
\text { gradient }\end{array}$ & $\begin{array}{c}\text { Up- } \\
\text { gradient }\end{array}$ & $\begin{array}{l}\text { On } \\
\text { Site }\end{array}$ & $\begin{array}{c}\text { Down- } \\
\text { gradient }\end{array}$ \\
\hline $\begin{array}{l}\text { Common Ions } \\
\text { Nitrate (as } N)^{f} \\
\text { Total Dissolved } \\
\text { Solids } 9\end{array}$ & $\begin{array}{l}10.0 \\
2388\end{array}$ & $\mathrm{mg} / \mathrm{L}$ & $\begin{array}{c}\sim 0.031 \\
1980\end{array}$ & $\begin{array}{l}45.177 \\
8020\end{array}$ & $3840^{0.522}$ & $2180^{1.581}$ & 10200 & $8620^{3.614}$ \\
\hline $\begin{array}{l}\text { Arsenic } \\
\text { Barium } \\
\text { Cadmi um } \\
\text { Chromium } \\
\text { Lead } \\
\text { Mercury } \\
\text { Molybdenum } \\
\text { Selenium } \\
\text { Silver }\end{array}$ & $\begin{array}{l}0.05 \\
1.0 \\
0.010 \\
0.05 \\
0.05 \\
0.002 \\
0.1 \\
0.01 \\
0.05\end{array}$ & $\begin{array}{l}\mathrm{mg} / \mathrm{L} \\
\mathrm{mg} / \mathrm{L} \\
\mathrm{mg} / \mathrm{L} \\
\mathrm{mg} / \mathrm{L} \\
\mathrm{mg} / \mathrm{L} \\
\mathrm{mg} / \mathrm{L} \\
\mathrm{mg} / \mathrm{L} \\
\mathrm{mg} / \mathrm{L} \\
\mathrm{mg} / \mathrm{L}\end{array}$ & $\begin{array}{c}<0.003 \\
\sim 0.014 \\
<0.001 \\
<0.002 \\
<0.001 \\
--- \\
<0.028 \\
<0.003 \\
---\end{array}$ & $\begin{aligned} & 0.252 \\
& \sim 0.0688 \\
& \sim 0.0013 \\
&<0.005 \\
&<0.001 \\
&--- \\
& 0.443 \\
& 0.0838 \\
&---\end{aligned}$ & $\begin{array}{l}\sim 0.0064 \\
\sim 0.0311 \\
<0.002 \\
<0.005 \\
<0.001 \\
--- \\
0.257 \\
0.0208 \\
-\ldots\end{array}$ & $\begin{array}{l}0.01 \\
\sim 0.0187 \\
<0.002 \\
0.010 \\
<0.01 \\
0.0002 \\
0.023 \\
\sim 0.0025 \\
<0.01\end{array}$ & $\begin{array}{l}0.68 \\
0.4 \\
0.055 \\
0.039 \\
0.0571 \\
0.0002 \\
19 . \\
0.685 \\
<0.01\end{array}$ & $\begin{array}{c}\sim 0.031 \\
\sim 0.0316 \\
<0.002 \\
0.112 \\
\sim 0.0015 \\
0.0002 \\
0.413 \\
0.05 \\
<0.01\end{array}$ \\
\hline $\begin{array}{l}\text { Radiological } \\
\text { Gross Alpha (excluding } \\
\text { radon and uranium) } \\
\text { Radium-226+228 } \\
\text { Thorium-230+232 } \\
\text { Urani um-234+238 }\end{array}$ & $\begin{array}{l}15 \\
5.0 \\
60 \\
30.0\end{array}$ & $\begin{array}{l}\mathrm{pCi} / \mathrm{L} \\
\mathrm{pCi} / \mathrm{L} \\
\mathrm{pCi} / \mathrm{L}\end{array}$ & $\begin{array}{l}<42 \\
<2 \\
<1 \\
11.92\end{array}$ & $\begin{array}{r}1.2 \\
2.26 \\
1489.69\end{array}$ & $\begin{array}{r}1.04 \\
1.08 \\
802.38\end{array}$ & $\begin{array}{l}1 \\
0.2 \\
22.77^{j}\end{array}$ & $\begin{array}{r}36 \\
18 \\
5994\end{array}$ & $\begin{array}{l}504.4 \\
1.72 \\
4.3 \\
999\end{array}$ \\
\hline $\begin{array}{l}\text { Herbicides } \\
2,4,5-T P \text { (Si vex) } \\
2,4-D\end{array}$ & $\begin{array}{r}10 \\
100\end{array}$ & $\begin{array}{l}\mu \mathrm{g} / \mathrm{L} \\
\mu \mathrm{g} / \mathrm{L}\end{array}$ & --- & --- & --- & $\begin{array}{l}<0.2 \\
<1.2\end{array}$ & $\begin{array}{l}<10 \\
<20\end{array}$ & $\begin{array}{l}<0.2 \\
<1.2\end{array}$ \\
\hline $\begin{array}{l}\quad \text { Pesticides and PCBs } \\
4,4 \text { '-DDT } \\
\text { Aldrin } \\
\text { Dieldrin } \\
\text { Endrin } \\
\text { Heptachlor } \\
\text { Heptachlor Epoxide } \\
\text { Methoxychlor } \\
\text { PCBs } \\
\text { Toxaphene } \\
\text { gamma-BHC (Lindane) }\end{array}$ & $\begin{array}{c}0.1 \\
0.1 \\
0.1 \\
0.2 \\
0.1 \\
0.1 \\
100 \\
0.5 \\
5 \\
4\end{array}$ & $\begin{array}{l}\mu \mathrm{g} / \mathrm{L} \\
\mu \mathrm{g} / \mathrm{L} \\
\mu \mathrm{g} / \mathrm{L} \\
\mu \mathrm{g} / \mathrm{L} \\
\mu \mathrm{g} / \mathrm{L} \\
\mu \mathrm{g} / \mathrm{L} \\
\mu \mathrm{g} / \mathrm{L} \\
\mu \mathrm{g} / \mathrm{L} \\
\mu \mathrm{g} / \mathrm{L} \\
\mu \mathrm{g} / \mathrm{L}\end{array}$ & $\begin{array}{l}--- \\
--- \\
--- \\
--- \\
--- \\
--- \\
--- \\
--- \\
---\end{array}$ & $\begin{array}{l}--- \\
--- \\
--- \\
--- \\
--- \\
--- \\
--- \\
--- \\
---\end{array}$ & $\begin{array}{l}--- \\
--- \\
--- \\
--- \\
--- \\
--- \\
--- \\
--- \\
---\end{array}$ & $\begin{array}{l}<0.1 \\
<0.05 \\
<0.1 \\
<0.12 \\
<0.05 \\
<0.05 \\
<0.5 \\
<2 \\
<5 \\
<0.05\end{array}$ & $\begin{array}{l}<0.1 \\
<0.052 \\
<0.1 \\
<0.12 \\
<0.052 \\
<0.052 \\
<5 \\
<2.1 \\
<48 \\
<0.8\end{array}$ & $\begin{array}{l}<0.1 \\
<0.05 \\
<0.1 \\
<0.1 \\
<0.05 \\
<0.05 \\
<0.5 \\
<2 \\
<5 \\
<0.05\end{array}$ \\
\hline
\end{tabular}

aStandards from the Uranium Mill Tailings Radiation Control Act, revised in 1986.

bColorado Department of Health Water Quality Control Division, Basic Standards for Groundwater. "Potentially Usable Quality" classification revised 10/17/91. Only the standards applicable to the GJPO Facility are 1isted.

$c_{A}$ "---" indicates no data available; a "<" indicates that the maximum concentration was below the detection limit (number shown is detection 1 imit); a " " indicates an approximate value (the value was outside the limits for which the instrument was calibrated).

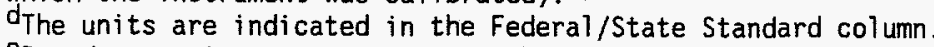

Eased on maximum concentrations observed from 1984 through 1993

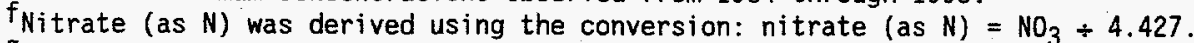

gThis is a site-specific standard calculated as background times 1.25 . The background value is based on the 1994 sampling events.

hMeasured values represent total gross alpha minus uranium activity using assumptions in footnote $i$.

iUranium concentrations, which were measured in milligrams per liter, were converted to picocuries per liter for comparison purposes. The conversion assumes equilibrium and an activity of $0.666 \mathrm{pCi} / \mu \mathrm{g}$.

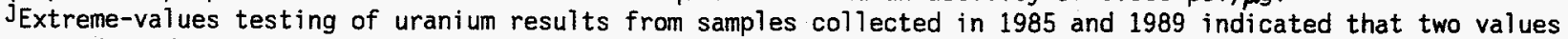
$(199.8 \mathrm{pCi} / \mathrm{L}$ and $83.25 \mathrm{pCi} / \mathrm{L})$ were outliers; these values from upgradient wells were not included in this table.

kpolychlorinated biphenyls include Aroclor 1016, 1221, 1232, 1242, 1248, 1254, and 1260. 
Table 7. (continued). Comparison of Federal and State of Colorado ${ }^{b}$ Groundwater Quality Standards to 1994 and Historical Maximum Concentrations in the Alluvial Aquifer

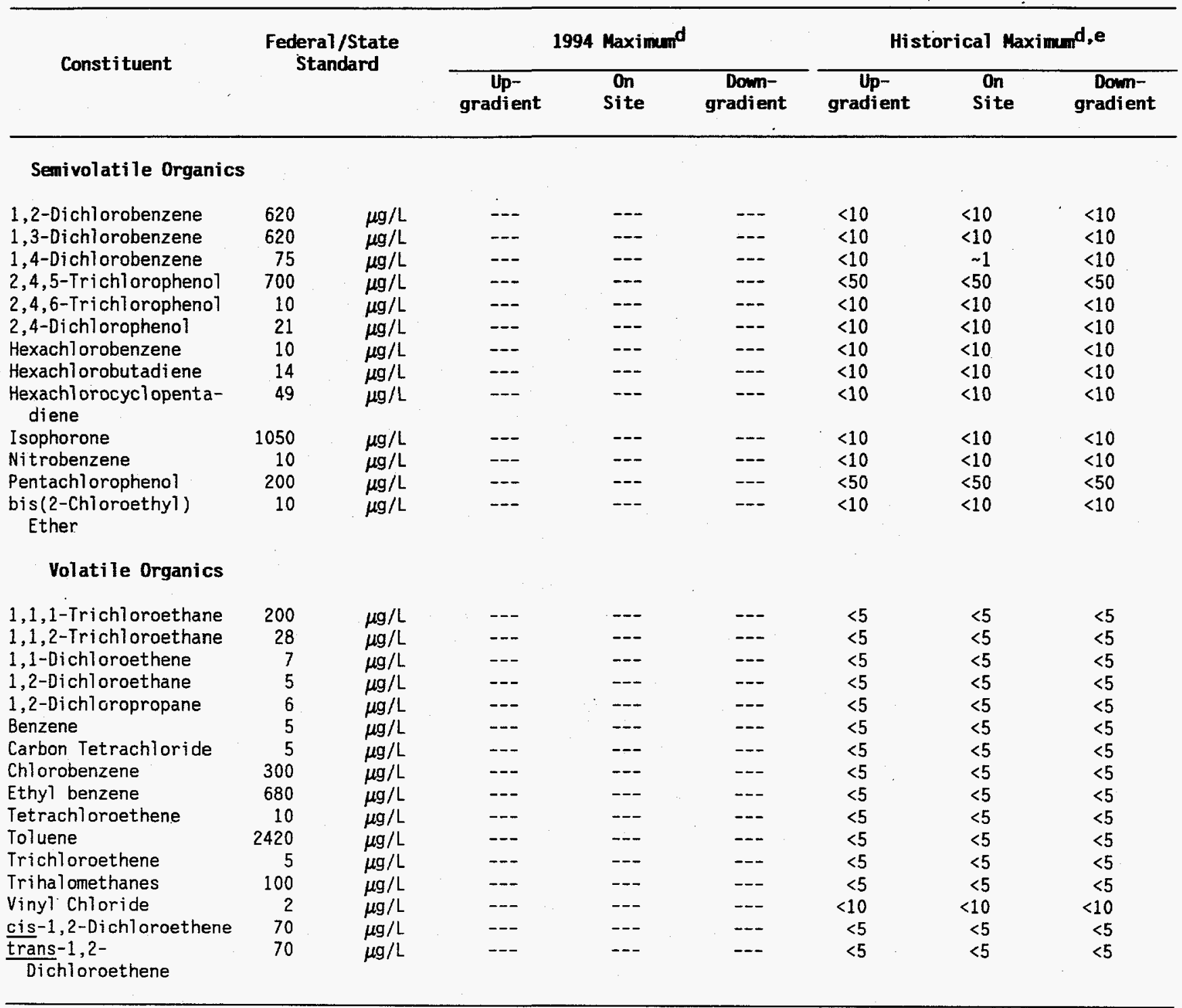

aStandards from the Uranium Mill Tailings Radiation Control Act, revised in 1986.

bColorado Department of Health Water Quality Control Division, Basic Standards for Groundwater. "Potentially Usable Quality" classification revised 10/17/91. Only the standards applicable to the GJPO Facility are listed.

$C_{A}$ "---" indicates no data available; a "<" indicates that the maximum concentration was below the detection limit (number shown is detection limit); a " " indicates an approximate value (the value was outside the limits for which the instrument was calibrated).

The units are indicated in the Federal/State Standard column.

Based on maximum concentrations observed from 1984 through 1993. 
molybdenum, sulfate, uranium, and vanadium. Water quality of the ponds and wetland areas is expected to improve over time through passive remediation of the alluvial groundwater.

Water quality within the Gunnison River is measured at four locations along its eastern shore: upstream of the facility, two locations adjacent to the facility, and downstream of the facility. Historical and 1994 maximum analyte concentrations within the Gunnison River are summarized and compared with applicable State standards in Table 8. Waterquality monitoring has indicated that, with one exception, neither discharges from the contaminated alluvial aquifer nor operations at the GJPO facility have affected water quality within the river. The one exception has been uranium discharges from the alluvial aquifer. During some sampling events, uranium concentrations have been measured at higher concentrations at the downstream sampling location than at the upstream or adjacent sampling locations. However, the State water-quality standard for uranium has never been exceeded at any of the locations (see Table 8). In 1994, all analyte concentrations observed in samples from the river, with the exception of manganese and sulfate, were below or within applicable State standards. The sources of manganese and sulfate in the river are believed to be upstream of the GJPO facility.

The GJPO facility is not on the 100-year or the 500-year floodplain of the Gunnison River (U.S. Army Corps of Engineers 1976); however, the Mesa County Housing and Urban Design Flood Insurance Rate Map (July 1978) places the facility within the 1,000-year floodplain. An earthen dike between the Gunnison River and the facility protects developed portions of the facility from potential flood events.

\subsection{Vegetation}

The habitat for plants on the GJPO facility is highly disturbed by operations on the site. The majority of the facility is covered with asphalt, concrete, gravel, road base, or lawn. Immediately adjacent to the facility, in areas that are relatively undisturbed, plant communities typical of a semidesert site are present. These upland areas support a greasewood plant community, which consists of saltgrass, sand dropseed, four-wing saltbush, and bottlebrush squirreltail. On the facility itself, disturbed upland areas support rabbitbrush, kochia, annual wheatgrass, Russian thistle, Russian knapweed, and cheatgrass (see Table 9 for scientific names).

The facility also supports small areas of wetland and riparian plant communities. The wetland plant community, edging the Gunnison River, North Pond, and wetland areas west of the North Pond, consists mainly of reed canary grass, hardstem bulrush, cattail, and willows. The riparian plant community, which occurs between the wetland and upland plant communities, is dotted with native vegetation such as Fremont cottonwood trees, skunkbush, and buffaloberry; however, naturalized exotics-saltcedar and Russian olive-dominate this community. 
Table 8. Comparison of State of Colorado Surface-Water Quality Standards to 1994 and Historical Maximum Concentrations in the Gunnison River

\begin{tabular}{|c|c|c|c|c|c|c|c|c|}
\hline \multirow[b]{2}{*}{ Constituent } & \multirow{2}{*}{\multicolumn{2}{|c|}{$\begin{array}{l}\text { State } \\
\text { Standard }\end{array}$}} & \multicolumn{3}{|c|}{1994 Maximum } & \multicolumn{3}{|c|}{ Historical Maximunc,d } \\
\hline & & & $\begin{array}{c}\text { Up- } \\
\text { Stream }\end{array}$ & $\begin{array}{l}\text { Adjacent } \\
\text { to Site }\end{array}$ & $\begin{array}{l}\text { Down- } \\
\text { Stream }\end{array}$ & $\begin{array}{c}\text { Up- } \\
\text { Stream }\end{array}$ & $\begin{array}{l}\text { Adjacent } \\
\text { to Site }\end{array}$ & $\begin{array}{l}\text { Down- } \\
\text { Stream }\end{array}$ \\
\hline \multicolumn{9}{|l|}{ Common Ions } \\
\hline $\begin{array}{l}\text { Chloride } \\
\text { Nitrate (as N) } \\
\text { Nitrite (as N) } \\
\text { Sulfate }\end{array}$ & $\begin{array}{c}250.0 \\
10.0 \\
0.05 \\
250.0\end{array}$ & $\begin{array}{l}\mathrm{mg} / \mathrm{L} \\
\mathrm{mg} / \mathrm{L} \\
\mathrm{mg} / \mathrm{L} \\
\mathrm{mg} / \mathrm{L}\end{array}$ & $\begin{array}{c}9.62 \\
1.353 \\
--- \\
415\end{array}$ & $\begin{array}{c}10.1 \\
1.33 \\
--- \\
415\end{array}$ & $\begin{array}{c}17.2 \\
1.326 \\
--- \\
414\end{array}$ & $\begin{array}{l}12.4 \\
6 \\
<0.304 \\
513\end{array}$ & $\begin{array}{c}12.6 \\
6 \\
--- \\
512\end{array}$ & $\begin{array}{l}80 \\
6 \\
<0.304 \\
584\end{array}$ \\
\hline \multicolumn{9}{|c|}{ Field Measurements } \\
\hline $\begin{array}{l}\text { Dissolved Oxygeng } \\
\mathrm{pH}\end{array}$ & $\begin{array}{l}6.0 \\
6.5-9.0\end{array}$ & $\mathrm{mg} / \mathrm{L}$ & $8.28-8.34$ & $8.30-8.65$ & $8.35-8.69$ & $\begin{array}{c}9.5 \\
7.20-9.04\end{array}$ & $\begin{array}{c}9.3 \\
7.29-9.19\end{array}$ & $\begin{array}{c}9.5 \\
7.33-9.01\end{array}$ \\
\hline \multicolumn{9}{|l|}{ Inorganics } \\
\hline \multicolumn{9}{|l|}{ Metals $\mathbf{i}$} \\
\hline $\begin{array}{l}\text { Arsenic } \\
\text { Cadmi um } \\
\text { Chromium+6 } \\
\text { Copper } \\
\text { Iron } \\
\text { Lead } \\
\text { Manganese } \\
\text { Mercury } \\
\text { Nickel } \\
\text { Selenium } \\
\text { Silver } \\
\text { Zinc }\end{array}$ & $\begin{array}{l}0.360 \\
0.021 \\
0.011 \\
0.042 \\
0.300 \\
0.032 \\
0.050 \\
0.0001 \\
0.295 \\
0.017 \\
0.001 \\
0.372\end{array}$ & $\begin{array}{l}\mathrm{mg} / \mathrm{L} \\
\mathrm{mg} / \mathrm{L} \\
\mathrm{mg} / \mathrm{L} \\
\mathrm{mg} / \mathrm{L} \\
\mathrm{mg} / \mathrm{L} \\
\mathrm{mg} / \mathrm{L} \\
\mathrm{mg} / \mathrm{L} \\
\mathrm{mg} / \mathrm{L} \\
\mathrm{mg} / \mathrm{L} \\
\mathrm{mg} / \mathrm{L} \\
\mathrm{mg} / \mathrm{L} \\
\mathrm{mg} / \mathrm{L}\end{array}$ & $\begin{array}{l}<0.005 \\
<0.002 \\
<0.005 \\
--- \\
\sim 0.0077 \\
<0.001 \\
0.0611 \\
--- \\
-- \\
0.0091 \\
--- \\
---\end{array}$ & $\begin{array}{l}<0.005 \\
<0.002 \\
<0.005 \\
--- \\
\sim 0.011 \\
<0.001 \\
0.0766 \\
--- \\
--- \\
0.0074 \\
--- \\
---\end{array}$ & $\begin{array}{l}<0.005 \\
<0.002 \\
<0.005 \\
--- \\
<0.006 \\
<0.001 \\
0.122 \\
--- \\
--- \\
0.0148 \\
--- \\
---\end{array}$ & $\begin{array}{l}0.011 \\
0.002 \\
0.0036 \\
0.056 \\
0.44 \\
0.059 \\
0.2 \\
<0.002 \\
0.005 \\
0.0096 \\
<0.0005 \\
1.07\end{array}$ & $\begin{array}{l}\sim 0.0051 \\
<0.002 \\
\sim 0.0045 \\
0.013 \\
0.1 \\
0.0118 \\
0.066 \\
<0.002 \\
<0.025 \\
0.014 \\
<0.0005 \\
0.86\end{array}$ & $\begin{array}{l}0.011 \\
<0.002 \\
\sim 0.0034 \\
0.05 \\
0.32 \\
0.027 \\
0.109 \\
<0.002 \\
0.021 \\
0.01 \\
0.0005 \\
1.72\end{array}$ \\
\hline \multicolumn{9}{|l|}{ Radiological } \\
\hline Urani um $^{j}$ & 40 & $\mathrm{pCi} / \mathrm{L}^{\mathrm{k}}$ & 7.61 & 8.86 & 13.99 & 10.42 & 14.39 & 22.644 \\
\hline \multicolumn{9}{|c|}{ 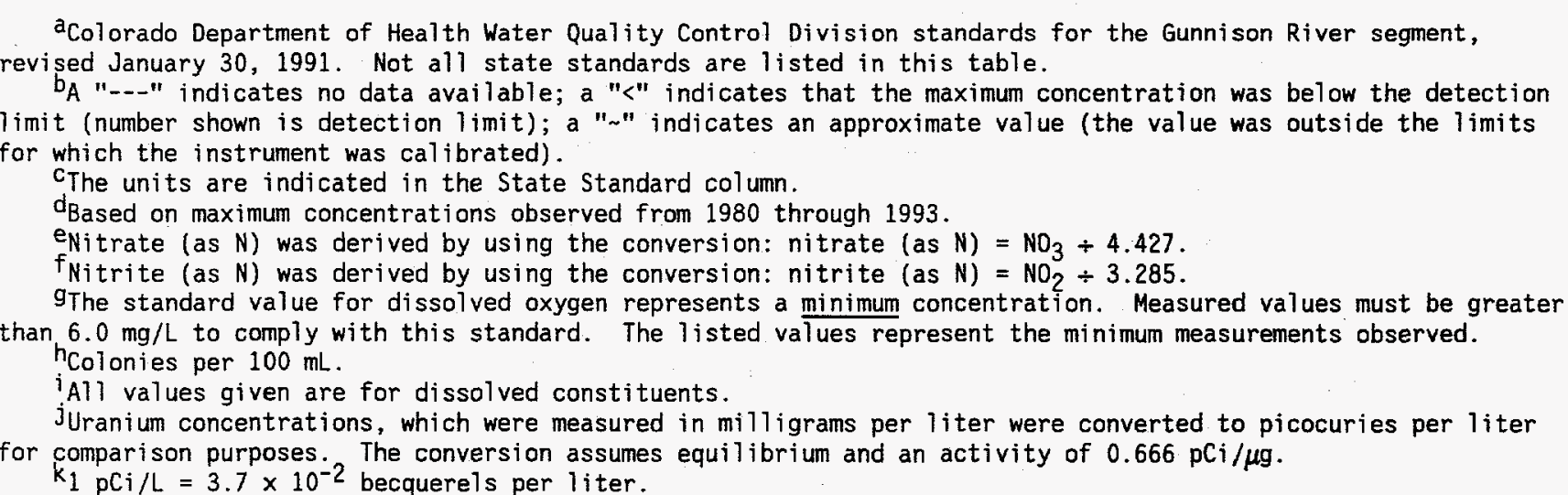 } \\
\hline
\end{tabular}




\begin{tabular}{|c|c|c|}
\hline Common Name & Scientific Name & \\
\hline alkaligrass & Puccinellia distans (Jacq.) Parl & \\
\hline alkali sacaton & Sporobolus airoides (Torr.) Torr. & \\
\hline annual wheatgrass & Eremopyrum triticeum (Gaertn.) Neuski & \\
\hline birch & Betula sp. & \\
\hline black medic & Medicago lupulina $\mathbf{L}$. & \\
\hline black oak & Quercus velutina & \\
\hline blue flax & Linum lewisii Pursh & \\
\hline blue grama & Bouteloua gracilis (Willd. ex Kunth.) Lag ex Griffiths & \\
\hline bluegrass & Poa pratensis $\mathrm{L}$. & \\
\hline bottlebrush squirreltail & Elymus elymoides (Raf.) Swezey & \\
\hline boxelder & Acer negundo $\mathrm{L}$. & \\
\hline buffalograss & Buchloe dactyloides (Nutt.) Engelm. & \\
\hline Canada wildrye & Elymus canadensis $\mathbf{L}$. & \\
\hline cattail & Typha katifolia L. & \\
\hline cheatgrass & Bromus tectorum $\mathbf{L}$. & \\
\hline columbine & Aquilegia sp. & \\
\hline coreopsis & Coreopsis tinctoria Nutt. & \\
\hline cornflower & Centaurea sp. & \\
\hline cotoneaster & Cotoneaster pyracantha (L.) Spach & \\
\hline crabapple & Malus sylvestris & \\
\hline crabgrass & Digitaria sp. & \\
\hline crested wheatgrass & Agropyron cristatum (L.) Gaerth. & \\
\hline fall-blooming chrysanthemum & Chrysanthemum sp. & \\
\hline forsythia & Forsythia suspensa (Thunb.) Vahl & \\
\hline fourwing saltbush & Atriplex canescens (Pursh) Nutt. & \\
\hline Fremont Barberry & Berberis fremontii Torr. & \\
\hline Fremont cottonwood & Populus fremontii S. Wats & \\
\hline galleta grass & Hilaria jamesii (Torr.) Benth. & \\
\hline greasewood & Sarcobatus vermiculatus (Hook) Torr. & \\
\hline green ash & Fraxinus pennsylvanica Marsh. & \\
\hline green foxtail & Setaria viridis (L.) Beauv. & \\
\hline green rabbitbrush & Chrysothamnus viscidiflorus (Hook) Nutt. & \\
\hline hardstem buirush & Scirpus acutus Muhl. ex Bigelow & \\
\hline honey locust & Gleditsia triacanthos $\mathbf{L}$. & \\
\hline horseweed & Conyza canadensis (L.) Cronq. & \\
\hline Indian ricegrass & Oryzopsis hymenoides (Roemer \& J. A. Schultes) Ricker ex Piper & \\
\hline Japanese barberry & Berberis thumbergii & \\
\hline kochia & Kochia scoparia (L.) Schrad. & \\
\hline linden & Tilia americana $\mathrm{L}$. & $\cdot$ \\
\hline maple & Acer sp. & \\
\hline marigold & Tagetes patula & \\
\hline mugo pine & Pinus mugo Turra & \\
\hline myrtle & Myrtus sp. & \\
\hline ninebark & Physocarpus opulifolius (L.) Maxim & \\
\hline ornamental juniper & Juniperus virginiana & \\
\hline plains cottonwood & Populus sargentii Dode & \\
\hline purple plum & Prunus sp. & \\
\hline redbud & Cercis canadensis & \\
\hline Redosier dogwood & Cornus stolonifera Michx. & \\
\hline reed canarygrass & Phalaris anundinacea $\mathrm{L}$. & \\
\hline rose & Rosa sp. & \\
\hline rubber rabbitbrush & Chrysothamnus nauseosus (Pallas ex Pursh) Britt. & \\
\hline Russian knapweed & Acroptilon repens (L.) D.C. & \\
\hline Russian olive & Elaeagnus angustifolia $\mathbf{L}$. & \\
\hline Russian thistle & Salsola kali $\mathrm{L}$. & \\
\hline
\end{tabular}


Table 9 (continued). Plant Species Observed On or Near the GJPO Facility

\begin{tabular}{|ll|}
\hline Common Name & \multicolumn{1}{|c|}{ Scientific Name } \\
\hline \hline saltcedar & \multicolumn{1}{|c|}{ Tamarix ramosissima Ledeb. } \\
saltgrass & Distichlis spicata (L.) Greene \\
sand dropseed & Sporobolus cryptandrus (Torr.) Gray \\
Scotch pine & Pinus sylvestris L. \\
Siberian elm & Ulmus pumila L. \\
silver buffaloberry & Shepherdia argentea (Pursh) Nutt. \\
skunkbush & Rhus trilobata var trilobata Nutt. \\
snapdragon & Antirrhinum majus \\
spirea & Spiraea X vanhoutii (Briot) Carr. \\
streambank wheatgrass & Elymus lanceolatus (Scribn. \& J.G. Sm) Gould \\
Uinta Basin hookless cactus & Sclerocactus glaucus (J. A. Purpus ex K Schum.) L. Benson \\
viburnum & Viburnum sp. \\
western wheatgrass & Pascopyrum smithii (Rydb.) A. Love \\
willow & Salix sp. \\
yarrow & Achillea millefolium L. \\
\hline
\end{tabular}

Remediated areas of the facility were revegetated in 1994 with native and adapted species. Species seeded on upland portions consisted of streambank wheatgrass, crested wheatgrass, Indian ricegrass, galleta grass, blue grama, and various perennial forbs. In wetland areas, seeded and transplanted species included reed canarygrass, western wheatgrass, alkaligrass, Canada wildrye, alkali sacaton, cattails, and hardstem bulrush. Riparian species consisted of Fremont cottonwood trees, skunkbush, buffaloberry, and willows, as well as species prescribed for the upland and wetland areas.

About 0.8 hectare ( 2 acres) of bluegrass lawn and various ornamental trees and shrubs surround the facility buildings. Adjacent to one facility building is a lawn area composed of two grass species adapted to the semidesert environment: buffalograss and blue grama.

No threatened or endangered plants have been observed on the GJPO facility. The Uintah Basin hookless cactus, federally listed as threatened, has been observed in the Grand Junction area (Moyer 1993), but it is unlikely that this species is growing on the facility.

\subsection{Wildlife}

The GJPO facility hosts a limited wildlife population because of the disturbed nature of the land and human activity at the site. However, the ponds, wetlands, and Gunnison River do attract several species of wildlife, and the ponds and Gunnison River attract several species of fish. During preparation of the GJPORAP RI/FS-EA (DOE 1989) and during a biota surveillance in 1993 (DOE 1993b), lists of wildlife observed or likely to occur near the GJPO facility were generated (see Table 10). 
Table 10. Wildlife Observed or Likely to Occur in the Vicinity of the GJPO Facility

\begin{tabular}{|c|c|c|c|}
\hline Scientific Name & Common Name & Scientific Name & Common Name \\
\hline Invertebrates & & Mammals & \\
\hline Cambarus Spp. & crayfish $^{\mathrm{a}}$ & $\overline{\text { Antilocapra americana }}$ & pronghorn antelope \\
\hline & & Canis latrans & coyote \\
\hline$\underline{\text { Fish }}$ & & Castor canadensis & beaver \\
\hline $\begin{array}{l}\text { Catostomus commersoni } \\
x \text { Catostomus discobolus }\end{array}$ & white sucker $\mathrm{x}$ bluehead sucker ${ }^{\mathrm{b}}$ & Cynomys leucurus & white-tailed prairie dog \\
\hline Catostomus latipinnis & flannelmouth sucker & $\begin{array}{l}\text { Felis cattus } \\
\text { Lepus califormicus }\end{array}$ & $\begin{array}{l}\text { feral cat } \\
\text { blacktail jackrabbit }\end{array}$ \\
\hline $\begin{array}{l}\text { Catostomus latipinnis } \\
x \text { C. commersoni }\end{array}$ & white $\mathrm{x}$ flannelmouth sucker & $\begin{array}{l}\text { Mephitis mephitis } \\
\text { Mustela frenata }\end{array}$ & $\begin{array}{l}\text { striped skunk } \\
\text { long-tailed weasel }\end{array}$ \\
\hline $\begin{array}{l}\text { Catostomus latipinnis } \\
x \text { Xyraunchen texanus }\end{array}$ & flannelmouth $\mathrm{x}$ razorback sucker & $\begin{array}{l}\text { Myotis leibii } \\
\text { Odocoileus hemionus }\end{array}$ & $\begin{array}{l}\text { small-footed myotis } \\
\text { mule deer }\end{array}$ \\
\hline Cyprinus carpio & carp $^{2}$ & Ondatra zibethicus & muskrat" \\
\hline Gila cypha & humpback chub & Peromyscus maniculatus & deer mouse \\
\hline Gila robusta & roundtail chub & Pipistrellus hesperus & western pipistrelle $e^{\circ}$ \\
\hline Ictalurus melas & black bullhead & Plecotus townsendii & Townsend's big-eared bat ${ }^{\circ}$ \\
\hline Lactalurus punctatus & channel catfish & Procyon lotor & raccoon \\
\hline Lepomis cyanellus & green sunfish & Rattus norvegicus & Norway rat \\
\hline Lepomis machrochirus & bluegill & Spilogale gracilis & spotted skunk \\
\hline Micropterus salmoides & largemouth bass & Sylvilagus audubonii & desert cottontail ${ }^{2}$ \\
\hline Notropis lutrensis & red shiner & Tamiasciurus hudsonicus & red squirrel" \\
\hline Notropis stramineus & sand shiner & Taxidea taxus & badger \\
\hline Pimephales promelas & flathead minnow & Urocyon cinereoargenteus & gray fox \\
\hline Ptychocheilus lucius & Colorado squawfish & Vulpes fulva & red fox \\
\hline Pomaxis nigromaculatus & black crappie & & \\
\hline Phinichthys osculus & speckled dace & Reptiles & \\
\hline Salmo clarki & cutthroat trout & Chelydra serpentina & snapping turtle \\
\hline Salmo gairdneri & rainbow trout & Chrysemys picta & painted turtle \\
\hline Salmo trutta & brown trout & Cnemidophorus velox & plateau whiptail \\
\hline & & Crotalus viridis concolor Woodbury & midget faded rattlesnake \\
\hline Amphibians & & Pituophis melanoleucus & bullsnake \\
\hline Ambystoma tigrinum & tiger salamander & Phrynosoma douglassii & short-horned lizard \\
\hline Bufo woodhousei & woodhouse toadc & Śceloporus graciosus & sagebrush lizard \\
\hline Rana catesbeiana & bullfrog & Sceloporus undulatus & eastern fence lizard \\
\hline Rana pipiens & leopard frog & Thamnophis elegans & wandering garter snake" \\
\hline
\end{tabular}

Species observed at the GJPO facility.

b" $x^{n}$ indicates a hybrid between the two species listed.

'Animals possibly observed at the GJPO facility, but which were only identified in general terms (i.e., bat, swallow, toad, etc.). 
Table 10 (continued). Wildlife Observed or Likely to Occur in the Vicinity of the GJPO Facility

\begin{tabular}{|c|c|c|c|}
\hline Scientific Name & Common Name & Scientific Name & Common Name \\
\hline \multicolumn{4}{|l|}{ Birds } \\
\hline$\overline{\text { Accipiter cooperii }}$ & Cooper's hawk & Corvus corax & common raven \\
\hline Aix sponsa & wood duck & Dendroica petechia & yellow warbler \\
\hline Alectoris chukar & chukar & Eremophila alpestris & horned lark \\
\hline Amphispiza Belli & sage sparrow & Euphagus cyanocephalus & Brewer's blackbirda \\
\hline Anas acuta & northern pintail & Falco sparverius & American kestrel ${ }^{2}$ \\
\hline Anas cyanoptera & cinnamon teal & Heliaeetus leucocephalus & bald eaglen \\
\hline Anas discors & blue-winged teal & Hirundo pyrrhonota & cliff swallow ${ }^{\mathrm{b}}$ \\
\hline Anas formosa & green-winged teal & Hirundo rustica & barn swallow \\
\hline Anas platyhynchos & mallard ${ }^{\mathrm{a}}$ & Junco hyemalis & dark-eyed juncon \\
\hline Aquila chrysaetos & golden eagle" & Meleagris gallopavo & wild turkey \\
\hline Ardea herodias & great blue heron ${ }^{\mathrm{a}}$ & Melosphiza melodia & song sparrow" \\
\hline Asio otus & long-eared owl & Molothrus ater & brown-headed cowbird \\
\hline Aythya valisineria & canvasback & Nycticorax nycticorax & black-crowned night heron \\
\hline Branta canadensis & Canada goose & Passerina amoena & lazuli bunting \\
\hline Bucephala albeola & bufflehead & Phalaenoptilus nuttallii & whippoorwill \\
\hline Bucephala ciangula & common goldeneye & Phasianus colchicus & ring-necked pheasant \\
\hline Buteo jamaicensis & red-tailed hawk & Pica pica & black-billed magpie \\
\hline Calamospiza melanocorys & lark bunting & Picoides pubescens & downy woodpecker \\
\hline Callipepla gambelii & Gambel's quail & Pipilo chlorurus & green-tailed towhee \\
\hline Carpodacus mexicanus & house finch" & Selasphorus platycercus & broad-tailed hummingbird" \\
\hline Cathartes aura & turkey vulture & Sialia currucoides & mountain bluebird \\
\hline Charadrius vociferus & killdeer & Spizella breweri & Brewer's sparrowb \\
\hline Chen caerulescens & snow goose & Stumello neglecta & western meadowlark \\
\hline Chondestes grammacus & lark sparrowb & Sturnus vulgaris & European starlinge \\
\hline Chordeiles minor & common nighthawk & Tachycineta thallassina & violet-green swallow \\
\hline Colaptes auratus & northern flicker & Turdus migratorius & American robin \\
\hline Columba livia & rockdove" & Tyrannus verticalis & western kingbird \\
\hline Contopus sordidulus & western wood pewee & Zenaida macroura & mourning dove" \\
\hline Corvus brachyrhynchos & American crow ${ }^{\mathrm{a}}$ & & \\
\hline
\end{tabular}

2Species observed at the GJPO facility.

'Animals possibly observed at the GJPO facility, but which were only identified in general terms (i.e., bat, swallow, toad, etc.). 
Two federally listed endangered fish species inhabit the Gunnison River adjacent to the facility-the Colorado squawfish and razorback sucker. The razorback suckers in the area are part of an experimental population that was reintroduced by wildlife agencies. A humpback chub was found in the Gunnison River near Dominguez Canyon (about 30 miles upstream of the facility) in 1983; while it is improbable, this species could occur near the facility.

Bald eagles (federally listed as endangered) nest and winter in Colorado. No nests have been observed in the Grand Junction area (DOE 1986), but in the winter, bald eagles have been observed in the riparian habitat near the GJPO facility.

In 1993, biota samples were collected to determine radiation doses to native aquatic organisms and determine compliance with the DOE (1991) dose limit of $1 \mathrm{rad}$ per day (rad/day). In the calculations, maximum 1992 surface-water concentrations of uranium-234, uranium-238, radium-226, and thorium-232 and standardized bioaccumulation rates, transfer factors, intake rates, and other factors were used to estimate total radiation dose to algae, fish, molluscs, crustaceans, muskrats, raccoons, herons, and ducks living on or near the GJPO facility. Doses were calculated according to the methods described by Baker and Soldat (1992). As shown in Table 11, all estimated doses were below the maximum limit of $1 \mathrm{rad} /$ day.

Table 11. Radiation Doses to Aquatic Organisms

\begin{tabular}{|ll||}
\hline Organism & $\begin{array}{c}\text { Dose } \\
\text { (rad/day) }\end{array}$ \\
\hline \hline Fish & 0.00311 \\
Mollusc & 0.0115 \\
Crustacean & 0.0115 \\
Algae & 0.110 \\
Muskrat & 0.115 \\
Raccoon & 0.00646 \\
Heron & 0.00445 \\
Duck & 0.00557 \\
\hline \hline
\end{tabular}

${ }^{\text {a }} \mathrm{DOE}$ dose limit is $1 \mathrm{rad} /$ day.

\subsection{Socioeconomics}

The GJPO facility is located in Mesa County, Colorado, immediately south and west of the Grand Junction city limits. An estimated 37,000 people live within the Grand Junction city limits, and an estimated 103,000 people live within Mesa County. The urban area that includes Grand Junction is populated by approximately 95,000 people. In 1990, a total of 12,810 housing units were present in Grand Junction, and 36, 250 were 
present in Mesa County. As of 1995 , the median income per household was $\$ 32,503$, and the unemployment rate was 4.3 percent (Grand Junction Chamber of Commerce 1995).

DOE, Rust, and ORNL together employ approximately 680 people at the GJPO facility. DOE employs 23 people, Rust employs about 610, and ORNL employs about 45 . Rust is the fourth largest employer in Mesa County and is the fifth largest employer in western Colorado. Goods and services purchased by Rust in FY 1995 totaled $\$ 17.7$ million, about 70 percent of which went to local businesses (Morrow 1995). The total funding for the facility (DOE, Rust, and ORNL) in FY 1995 was \$88 million (Weisner 1995 and Meyer 1995). The 1995 Rust payroll was $\$ 29.8$ million (Barker 1995), and the average annual salary of a Rust employee was $\$ 40,370$.

\subsection{Human Health}

Removal of all known exterior UMT waste under GJPORAP eliminated the primary source of radiation exposure to humans on the GJPO facility. Only interior UMT waste remains within buildings on the facility, and it will be removed during the next 3 years under GJPORAP. UMT waste within contaminated buildings has either been encapsulated, so that above-background levels of radiation are not emitted, or it is in areas (under the floor, in the attic) where humans cannot be exposed.

Situations in which an on-site worker potentially could be exposed to above-background levels of radiation would be during preparation and analysis of radiological samples (in the Analytical Laboratory and Sample Preparation Plant), during handling of radon sources (in the Radon Laboratory), as a result of a break in the encapsulation material in contaminated buildings, or during GJPORAP remedial activities. If exposure were to occur, the primary pathways would be (1) inhalation and ingestion of airborne radioparticulates, (2) inhalation of radon and radon daughters, or (3) direct exposure to gamma radiation from mill tailings.

Exposure of workers to radiation is prevented by the implementation of engineering controls, radiological controls, and health and safety measures. Laboratory workers follow the procedures in the Analytical Chemistry Laboratory Chemical Hygiene Plan (Rust Geotech 1994a) and Radon/Environmental Sciences Laboratories Chemical Hygiene Plan (Rust Geotech 1994e) to prevent radiation exposure. Engineering controls such as venting systems and fume hoods also prevent exposure. During GJPORAP remedial activities, inhalation and ingestion of airborne radioparticulates is prevented by standard dust-control measures such as water sprays and HEPA vacuums. Respirators may by worn by workers to prevent exposure in some instances. Monitoring of occupational exposure is conducted in accordance with requirements in the Health and Safety Manual, Volume 2 (Rust Geotech 1995b). With implementation of these measures, workers are not exposed to radiation levels above background.

The potential for adverse health effects was quantitatively evaluated in the GJPORAP RI/FS-EA (DOE 1989). Under a remedial action scenario that involved removal of 
more than 400,000 tons of UMT waste, it was determined that the risk to workers was sufficiently low that no fatal cancers would occur as a result of remedial action. Health risks associated with radiation exposure from current activities on the GJPO facility are many times lower than those calculated for GJPORAP remedial action.

The primary risks to human health under present conditions are from nonradiological hazards such as (1) falling, tripping, or slipping; (2) industrial accidents; or (3) exposure to chemicals. The risk of hazards in the first two categories is about the same as for workers in any office setting or on any construction site. Implementation of health and safety measures such as job-site safety meetings and the "buddy system" helps to reduce these risks. The potential for laboratory workers to be exposed to chemicals is reduced by implementation of laboratory hygiene plans (Rust Geotech 1994a and 1994e).

Current operations at the GJPO facility do not present a health risk to the general public. Air emissions to the general public are well below Federal and State standards (see Section 4.3, Air Quality), and contaminated groundwater beneath the facility is not available for human use (see Sections 4.5 and 4.6, Groundwater and Surface Water, respectively). Because the general public's access to the facility is controlled, the potential for exposure to radiological areas and chemicals is minimal or nonexistent. 
page left

intentionally blank 


\subsection{Environmental Impacts}

This section describes the environmental impacts that would occur from implementing the No Action, Proposed Action, and Shutdown Alternatives. Only those elements of the environment that would be affected by the alternatives are discussed. Because cultural resources, prime or unique farmlands, and threatened and endangered plants do not occur on or adjacent to the facility, these elements are not discussed in this section. Other elements of the environment, such as land use, visual resources, floodplains, wetlands, geology, mineral resources, and recreation, may occur on the facility but are not affected by activities associated with the alternatives; therefore, they also are not discussed in this section. Table 12 summarizes the impacts that would occur to environmental resources under each alternative.

\subsection{Transportation}

\subsubsection{No Action and Proposed Action Alternatives}

Operations under the No Action and Proposed Action Alternatives would have few adverse impacts on transportation (see Section 4.1 for description of transportation under the No Action Alternative). Traffic volume under the Proposed Action Alternative would be similar to that under the No Action Alternative except during the construction of buildings, when it would increase slightly. No changes in the number of vehicle accidents in the employee parking lot or on the facility would be anticipated.

Environmental impacts associated with the transportation of UMT waste to the UMTRA Cheney Disposal Cell are discussed in the Environmental Impact Statement for the Climax Mill Site (DOE 1986) and the Administrative Record; Grand Junction Projects Office Remedial Action Project, Direct Truck Haul of Residual Radioactive Material to the Cheney Repository (DOE 1993a).

Under either alternative, a small potential for on-site transportation accidents (involving vehicles other than those hauling UMT waste to the UMTRA Cheney Disposal Cell) that could result in a spill of hazardous, low-level, mixed low-level, or PCB waste would exist. The potential might be slightly higher under the Proposed Action Alternative if capabilities of the Analytical Laboratory were expanded and more wastes were produced. This potential would be reduced by following established procedures for on-site waste transportation outlined in Procedure 7.4, "On-Site Waste Transfer," in the Environmental Services Desk Instructions (Rust Geotech 1994b). Generally, no more than 150 liters (40 gallons) of waste would be transported at one time. If an accidental spill were to occur, procedures in Chapter 12, "Hazardous Materials Contingency Plan and Emergency Procedures" of the GJPO Emergency Preparedness and Response Plan (DOE 1994b) would 
Table 12. Summary Table of Environmental Impacts

\begin{tabular}{|c|c|c|c|}
\hline \multirow{2}{*}{$\begin{array}{l}\text { Environmental } \\
\text { Element }\end{array}$} & \multicolumn{3}{|c|}{ Alternative } \\
\hline & $\begin{array}{c}\text { No Action } \\
\text { (continuation of present-day } \\
\text { activities) }\end{array}$ & $\begin{array}{l}\text { Proposed Action } \\
\text { (expansion and upgrade of } \\
\text { facilities and operations) }\end{array}$ & $\begin{array}{l}\text { Shutdown } \\
\text { (termination of } \\
\text { operations) }\end{array}$ \\
\hline Transportation & $\begin{array}{l}\text { Small potential for transportation } \\
\text { accidents and/or spills }\end{array}$ & $\begin{array}{l}\text { Small potential for transportation } \\
\text { accidents and/or spills }\end{array}$ & $\begin{array}{l}\text { Potential for } \\
\text { transportation accidents } \\
\text { and/or spills eliminated }\end{array}$ \\
\hline Noise & $\begin{array}{l}\text { Noise levels generally within the } \\
\text { range characteristic of urban settings; } \\
\text { temporary increase in noise levels } \\
\text { from building renovation and } \\
\text { remediation activities }\end{array}$ & $\begin{array}{l}\text { Noise levels generally within the } \\
\text { range characteristic of urban settings; } \\
\text { temporary increase in levels from } \\
\text { building renovation, remediation, and } \\
\text { construction activities }\end{array}$ & $\begin{array}{l}\text { Noise levels reduced } \\
\text { (more characteristic of a } \\
\text { rural setting) }\end{array}$ \\
\hline Air Quality & $\begin{array}{l}\text { Negligible releases of radiological } \\
\text { constituents from remedial action, the } \\
\text { instrument calibration facilities, radon } \\
\text { calibration chambers, Analytical } \\
\text { Laboratory, and Baghouse; negligible } \\
\text { releases of nonradiological } \\
\text { constituents from the Analytical } \\
\text { Laboratory and Environmental } \\
\text { Instrumentation Laboratory }\end{array}$ & $\begin{array}{l}\text { Same radiological and nonradiological } \\
\text { releases as No Action Alternative; } \\
\text { slight, temporary increase in } \mathbf{P M}_{10} \\
\text { concentrations during construction } \\
\text { activities }\end{array}$ & $\begin{array}{l}\text { Sources of air pollutants } \\
\text { eliminated }\end{array}$ \\
\hline Soils & $\begin{array}{l}\text { Minor potential for soil } \\
\text { contamination from accidental fuel or } \\
\text { waste spills or from sewer-line leaks }\end{array}$ & $\begin{array}{l}\text { Minor potential for soil } \\
\text { contamination from accidental fuel or } \\
\text { waste spills or from sewer-line leaks }\end{array}$ & $\begin{array}{l}\text { Potential for accidental } \\
\text { fuel or waste spills or for } \\
\text { sewer-line leaks eliminated }\end{array}$ \\
\hline Groundwater & $\begin{array}{l}\text { Negligible potential for degradation } \\
\text { of groundwater quality from } \\
\text { accidental fuel or waste spills or from } \\
\text { sewer-line leaks }\end{array}$ & $\begin{array}{l}\text { Negligible potential for degradation } \\
\text { of groundwater quality from } \\
\text { accidental fuel or waste spills or from } \\
\text { sewer-line leaks }\end{array}$ & $\begin{array}{l}\text { Potential for accidental } \\
\text { fuel or waste spills or } \\
\text { sewer-line leaks eliminated }\end{array}$ \\
\hline Surface Water & $\begin{array}{l}\text { Negligible potential for degradation } \\
\text { of surface-water quality from } \\
\text { accidental fuel or waste spills }\end{array}$ & $\begin{array}{l}\text { Negligible potential for degradation } \\
\text { of surface-water quality from } \\
\text { accidental fuel or waste spills }\end{array}$ & $\begin{array}{l}\text { Potential for accidental } \\
\text { fuel or waste spills } \\
\text { eliminated }\end{array}$ \\
\hline Vegetation & $\begin{array}{l}\text { Negligible potential for vegetation } \\
\text { destruction or damage from surface } \\
\text { disturbances or fuel or waste spills }\end{array}$ & $\begin{array}{l}\text { Same impacts as No Action } \\
\text { Alternative; temporary loss of } \\
0.2 \text { hectare of vegetation from new } \\
\text { construction }\end{array}$ & $\begin{array}{l}\text { Potential for vegetation } \\
\text { destruction from site } \\
\text { operations eliminated; } \\
\text { some death of } \\
\text { ornamentals from lack of } \\
\text { watering }\end{array}$ \\
\hline Wildlife & $\begin{array}{l}\text { Negligible potential for damage to } \\
\text { aquatic life from accidental fuel or } \\
\text { waste spills; possible temporary } \\
\text { displacement of wildlife from building } \\
\text { renovation and remediation }\end{array}$ & $\begin{array}{l}\text { Same impacts as No Action } \\
\text { Alternative; possible permanent } \\
\text { displacement of wildlife from increase } \\
\text { in human activity at new buildings }\end{array}$ & $\begin{array}{l}\text { Potential for displacement } \\
\text { or loss of wildlife } \\
\text { eliminated; slight increase } \\
\text { in wildlife numbers and } \\
\text { diversity }\end{array}$ \\
\hline Socioeconomics & $\begin{array}{l}\text { Beneficial impacts to local economy } \\
\text { from business expenditures and } \\
\text { continued employment of } 680 \text { people }\end{array}$ & $\begin{array}{l}\text { Beneficial impacts to local economy } \\
\text { from business expenditures and } \\
\text { continued employment of } 680 \text { people }\end{array}$ & $\begin{array}{l}\text { Adverse impacts to local } \\
\text { economy from loss of } \\
\text { revenues associated with } \\
\text { DOE facility and loss of } \\
\text { up to } 680 \text { jobs }\end{array}$ \\
\hline Human Health & $\begin{array}{l}\text { Negligible potential for human } \\
\text { exposure to chemicals, toxic } \\
\text { substances, or radioactive sources }\end{array}$ & $\begin{array}{l}\text { Negligible potential for human } \\
\text { exposure to chemicals, toxic } \\
\text { substances, or radioactive sources }\end{array}$ & $\begin{array}{l}\text { Potential for human } \\
\text { exposure to chemicals, } \\
\text { toxic substances, or } \\
\text { radioactive sources } \\
\text { eliminated }\end{array}$ \\
\hline
\end{tabular}


be followed. Chapter 12 satisfies the contingency plan requirements in the Code of Colorado Regulations (6 CCR 1007-3, Part 265, Subpart D) because DOE-GJPO currently maintains Part A interim status for the storage of hazardous and mixed wastes.

The potential for spill accidents during off-site, commercial transport of hazardous, lowlevel, mixed low-level, and PCB wastes would be low because of the relatively small volumes (about 500 kilograms, on average) shipped and low frequency of shipments (approximately two shipments per year). The potential for spills would be reduced by complying with U.S. Department of Transportation regulations for packaging and shipping and by following procedures in Procedure 5.5, "Shipment of Hazardous Waste," of the Stores, Property, and Transportation Desktop Manual (Rust Geotech 1994g). All of these regulations and procedures are currently implemented.

For the purpose of evaluating potential human health impacts associated with off-site transportation of regulated wastes, a review of the transportation analysis reported in the Draft Waste Management Programmatic Environmental Impact Statement (WM/PEIS) (DOE 1995a) was conducted. In this document, transportation impacts were analyzed on the basis of the estimated total volume of low-level and mixed low-level wastes that would be transported by the entire DOE complex during the next 20 years. The estimated total volume of wastes was greater than 22 million cubic feet and was transported over a total of 500 million miles. Given these estimates, a maximum of 9.3 latent cancer fatalities to the public was predicted from waste transportation by the entire DOE complex during the 20-year period.

During a 20 -year period, DOE-GJPO would transport approximately 1,000 cubic feet (biased high because of varying densities of materials) of waste over an estimated maximum distance of 20,000 miles. If this waste were composed entirely of low-level waste, the predicted number of latent cancer fatalities would be a minute fraction $(<0.00001)$ of those predicted for the DOE complex as a whole. In addition, the WM/PEIS considered low-level waste from all sources, including process wastes, which generally contain higher concentrations of radioactive material than the low-level wastes generated at the GJPO facility.

\subsubsection{Shutdown Alternative}

Under the Shutdown Alternative, daily traffic on local roads and the facility, consisting of 600-660 employee-owned vehicles and about 50 service vehicles, would be eliminated. Roads primarily affected by this alternative would be U.S. Highway 50 and B 3/4 Road. Because of the reduced traffic, vehicular emissions would be greatly decreased and the potential for accidents involving vehicles would be reduced. The potential for transportation-related spills of hazardous, low-level, mixed low-level, or PCB wastes also would be eliminated. 


\subsection{Noise}

\subsubsection{No Action and Proposed Action Alternatives}

Under the No Action Alternative, temporary increases in noise levels would result primarily from routine renovation activities, GJPORAP remedial actions, and the use of motorized vehicles (see Section 4.2). With rare exceptions, noise levels would be well below the Federal action level of 85 decibels. Under the Proposed Action Alternative, noise levels would be similar to those under the No Action Alternative, although temporary noise-level increases would occur slightly more often because of additional building construction and GJPORAP remedial actions. Administrative or engineering controls would be considered when noise levels exceeded 85 decibels, in accordance with regulations in 29 CFR Section 1910.95, "Occupational Safety and Health, Occupational Noise Exposure."

\subsubsection{Shutdown Alternative}

Under the Shutdown Alternative, noise associated with GJPO facility operations would be eliminated.

\subsection{Air Quality}

\subsubsection{No Action and Proposed Action Alternatives}

Under the No Action Alternative, radon emissions from the instrument calibration facilities and radon calibration chambers would continue to be released at a rate of approximately $0.52 \mathrm{Ci} / \mathrm{yr}$. Radioparticulate and nonradiological air particulate emissions would continue to be well below Federal and State standards (see Section 4.3).

Air emissions under the Proposed Action Alternative are expected to be similar to those under the No Action Alternative. Because of dust-control measures, radioparticulates would not substantially increase during GJPORAP remedial actions. Although sample volume in the laboratories might increase somewhat as laboratory space is expanded, implementation of waste minimization practices would minimize increases in radiological air emissions. Construction activities might cause a slight, temporary increase in $\mathbf{P M}_{10}$ concentrations but would not substantially affect air quality.

\subsubsection{Shutdown Alternative}

Under the Shutdown Alternative, all emissions from facility operations would be eliminated. 


\subsection{Soils}

\subsubsection{No Action and Proposed Action Alternatives}

Under the No Action and Proposed Action Alternatives, areas of unknown, radiologically contaminated soils could be discovered during GJPORAP remedial actions. These soils would be removed upon discovery and hauled to the UMTRA Cheney Disposal Cell.

Under either alternative, soil contamination could result if a waste or fuel spill occurred on the facility. Hazardous, low-level, mixed low-level, or PCB wastes would be transported across the facility from satellite accumulation areas to Waste Accumulation Modules or to the Hazardous and Mixed Waste Storage Unit. However, spills would be unlikely because of the primary and secondary containment features of the packaging and waste storage areas. If a spill did occur, the affected area would be small because of the relatively small volumes (less than 40 gallons, on average) of waste typically transported. Procedures established in Chapter 12 of the GJPO Emergency Preparedness and Response Plan (DOE 1994b.)-"Hazardous Materials Contingency Plan and Emergency Procedures"-would be followed if a spill occurred. Contaminated soils would be immediately treated and/or contained so that the affected area would be minimized.

Another source of potential soil contamination would be the sewer pipelines, from which sewer effluent could leak. Currently, there is no leak detection system for the pipelines. If a leak should occur, an unknown area of soil might be contaminated. If the leak were detected, contaminated soils would be treated and/or disposed of properly.

\subsubsection{Shutdown Alternative}

Because operations would not occur at the GJPO facility under this alternative, no impacts to soils would occur.

\subsection{Groundwater}

\subsubsection{No Action and Proposed Action Alternatives}

Under the No Action and Proposed Action Alternatives, groundwater-quality impacts could occur as a result of a fuel or waste spill or sewer-line leak. Migration of the spilled or leaked contaminant would be via the soil or more likely via the surface ponds that are in hydrologic contact with the underlying alluvial aquifer. However, it would be unlikely for the spilled contaminant to adversely affect groundwater quality because of the generally small quantities of fuel or waste transported or stored on the facility.

Because all known UMT waste that historically contaminated the groundwater was removed by July 1, 1994, groundwater quality should improve over time by means of natural flushing (see Section 4.5). Concentrations of water-quality constituents 
associated with the historic leaching of uranium mill tailings are expected to be below applicable standards within 50 to 80 years.

\subsubsection{Shutdown Alternative}

Adverse impacts to groundwater would not occur under this alternative because operations would not occur at the GJPO facility. Groundwater quality should continue to improve over time by means of natural flushing.

\subsection{Surface Water}

\subsubsection{No Action and Proposed Action Alternatives}

Under the No Action and Proposed Action Alternatives, surface-water quality of the North Pond, South Pond, and wetlands is expected to improve over time through passive remediation of the alluvial groundwater (see Section 4.6). Surface-water impacts could occur as a result of a fuel or waste spill near or directly into a water source; however, it would be unlikely for the spilled contaminant to adversely affect water quality because of the generally small quantities of waste and fuel stored or transported on the facility.

\subsubsection{Shutdown Alternative}

Because operations would not occur at the GJPO facility under this alternative, no adverse impacts to surface water would occur. Water quality within the North Pond, South Pond, and wetlands would improve over time through passive remediation of the alluvial groundwater.

\subsection{Vegetation}

\subsubsection{No Action Alternative}

Under the No Action Alternative, land disturbances from new construction activities would not occur, and the potential for vegetative destruction or damage from waste or fuel spills would be small. If a spill were to occur, the affected area would be minimal because of the relatively small volumes (typically less than 40 gallons) of waste transported across the site or small volumes of fuel contained on the facility. Procedures established in Chapter 12 of the GJPO Emergency Preparedness and Response Plan (DOE 1994b) --"Hazardous Materials Contingency Plan and Emergency

Procedures"-would be followed if a spill occurred. The contaminated material would be immediately treated and/or contained and disposed of properly, and the vegetation, if destroyed or removed, would be replaced. 


\subsubsection{Proposed Action Alternative}

Under the Proposed Action Alternative, impacts to vegetation would be similar to those under the No Action Alternative. Additional minor impacts would occur as a result of building construction. Most of the proposed construction would occur in areas covered with asphalt or road base. Construction of the Northwest Office Complex, the new Analytical Chemistry Laboratory, and the Medical Facility, however, would result in the removal of about 0.2 hectare $(0.5$ acre) of vegetation, consisting mainly of upland seeded species, bluegrass lawn, and ornamental trees and shrubs. This loss in vegetated area would be offset by the revegetation of disturbed ground around the newly constructed buildings.

\subsubsection{Shutdown Alternative}

Because operations would not occur at the GJPO facility under this alternative, adverse impacts associated with potential waste or fuel spills or construction activities would not occur. Areas of bluegrass lawn and some of the ornamental trees and shrubs would die because of the lack of routine watering. Over the long term, drought-resistant species would encroach in these areas.

\subsection{Wildlife}

\subsubsection{No Action Alternative}

Under the No Action Alternative, renovation and GJPORAP activities might increase noise levels temporarily but not to the extent that wildlife would be displaced permanently. Potential waste or fuel spills would not substantially affect wildlife or aquatic life because (1) the spill would be contained, and cleanup measures would be implemented immediately and (2) spills into surface-water sources would be of a relatively low volume and would be diluted immediately. The greatest potential impact would be to aquatic life (e.g., a frog or frog eggs) present at the actual spill location.

\subsubsection{Proposed Action Alternative}

Under the Proposed Action Alternative, construction and GJPORAP activities would cause temporary increases in noise levels, resulting in temporary displacements of wildlife. A permanent displacement of wildlife might result from the increase in human activity associated with use of a new building, such as the Northwest Office Complex. Most of the new construction would occur in areas covered by asphalt or road base, which support minimal or no wildlife habitat. Construction of the Northwest Office Complex, the new Analytical Chemistry Laboratory, and the Medical Facility, however, would result in the removal of about 0.2 hectare $(0.5$ acre $)$ of upland seeded species, bluegrass lawn, and ornamental trees and shrubs. Removal of this vegetation could 
result in the destruction of 1-5 bird nests and temporary displacement of 2-3 rabbits or squirrels. Destroyed habitat would be replaced by revegetating disturbed ground around the newly constructed buildings.

\subsubsection{Shutdown Alternative}

Wildlife would benefit from the elimination of noise and operations at the GJPO facility. The numbers and species of wildlife visiting and inhabiting the facility would most likely increase slightly from current levels.

\subsection{Socioeconomics}

\subsubsection{No Action and Proposed Action Alternatives}

Under the No Action and Proposed Action Alternatives, continuation or expansion of GJPO facility operations would not negatively affect current socioeconomic trends in the Grand Junction area (see Section 4.9). For the most part, the city and local businesses would continue to benefit from the employment of 680 people who buy homes, goods, and services in the area. The purchasing of local goods and services by the GJPO would continue as in the past until 2000 , when the rate may decrease from the cessation of GJPORAP activities.

\subsubsection{Shutdown Alternative}

Shutdown of operations at the GJPO facility would result in the loss of up to 680 jobs. Employees at the GJPO currently constitute 2.5 percent of the population of Grand Junction. Local businesses and services would be adversely affected by the curtailing of material, equipment, and supply purchases by DOE and by the elimination of wages and salaries paid to GJPO employees and subcontracted personnel (see Section 4.9).

\subsection{Human Health}

\subsubsection{No Action and Proposed Action Alternatives}

Under the No Action and Proposed Action Alternatives, workers involved in GJPORAP activities and personnel working in the Analytical Laboratory, Radon Laboratory, Sample Preparation Plant, Petrology Laboratory, Environmental Sciences Laboratory, Maintenance Shop, and Hazardous and Mixed Waste Storage Unit would potentially be exposed to chemicals, toxic substances, and radioactive sources (see Section 4.10). All these personnel would be required to follow established operational, health, and safety procedures to reduce or eliminate their exposure to harmful elements. Additionally, standard operating procedures would require engineering or radiological controls to be 
implemented to reduce exposure levels. Actual procedures that would be followed are discussed in numerous plans, manuals, and desk instructions (see individual subsections under Section 3.1, No Action Alternative, and Section 4.10).

Personnel involved in renovation, construction, and GJPORAP activities would have the highest exposure to tripping hazards and industrial accidents. The risk to personnel would be about the same as that for workers on any other construction site. On the GJPO facility, renovation, construction, and GJPORAP personnel would be required to attend job-site safety meetings and implement the "buddy system" to help reduce injury risks. The potential for other workers on the facility and the general public to be exposed to chemicals, toxic substances, radioactive sources, tripping hazards, or industrial accidents would be low, or about the same as that for a worker in a similar office environment.

\subsubsection{Shutdown Alternative}

Under the Shutdown Alternative, the potential for workers and the general public to be exposed to chemicals, toxic substances, radioactive sources, tripping hazards, or industrial accidents would be nonexistent because operations at the facility would be discontinued. The primary adverse impact to human health would be psychological in nature. Most of the approximately 680 employees, whose jobs would be terminated, would have to deal with the stress of finding a new job and possibly moving their families to new locations.

\subsection{Environmental Justice Considerations}

Executive Order No. 12898, Federal Actions to Address Environmental Justice in Minority Populations and Low-Income Populations, states that Federal programs and actions shall not disproportionately affect minority or low-income populations. None of the alternatives addressed in this EA would adversely affect any particular cultural or socioeconomic group of people more than the population as a whole. The 680 employees at the GJPO facility and the community of Grand Junction, both of which would be affected by the alternatives, are culturally and economically diverse.

\subsection{Cumulative Impacts}

\subsubsection{No Action Alternative}

The cumulative effects of the No Action Alternative generally would be no more or less in magnitude or significance than the individual effects delineated in the preceding sections. Slight adverse effects would be associated with continuation of current noise levels and traffic volumes on and adjacent to the facility. The potential for waste or fuel spills that could negatively affect soils, groundwater, surface water, vegetation, wildlife, or 
human health would continue to be negligible. If a spill occurred, however, in-place emergency procedures would require prompt mitigation of the effects.

Positive effects of the alternative would center on socioeconomic benefits. Continued operation of the GJPO facility would imply ongoing employment for about 680 people from the Grand Junction area and continuation of these individuals' contributions (e.g., housing, retail sales, and community services) to the local economy. Further, it would imply continued local procurement of a variety of materials, equipment, supplies, and subcontracted labor and services. The socioeconomic impacts of continued facility operations, which were associated with a funding of $\$ 88$ million in FY 1995, would be highly beneficial.

\subsubsection{Proposed Action Alternative}

Expansion of the facility's capabilities and the consequent need for additional or upgraded office and laboratory space under the Proposed Action Alternative would result in short-term increases in noise and traffic volumes on the facility and short-term increases in airborne $\mathrm{PM}_{10}$ concentrations. With the expansion of laboratory capabilities, an increase in waste generation would most likely occur, resulting in a slightly higher potential for transportation accidents involving waste spills.

A slight increase in nonregulated solid waste generation (about 2,000 cubic meters $[2,600$ cubic yards]) and UMT waste generation (about 9,100 cubic meters $[11,930$ cubic yards]) over a period of 3 years would result from the demolition of buildings under GJPORAP. The amount of solid waste, which physically would take up an area 12.5 cubic meters (41 cubic feet) in size, would not substantially affect available capacity at the Mesa County landfill. The landfill typically receives 1,100 to 1,400 cubic meters of solid waste per day, and on a busy day, may receive 2,000 cubic meters of solid waste (Rulf 1995). Likewise, the deposition of the additional UMT waste at the UMTRA Cheney Disposal Cell would not substantially affect the available capacity of the cell. The additional volume of waste represents about 6 percent of the cell's total capacity.

Overall, beneficial and adverse impacts of this alternative would be similar to those under the No Action Alternative.

\subsubsection{Shutdown Alternative}

Termination of operations under the Shutdown Alternative would have several long-term beneficial impacts. Traffic volumes on and adjacent to the facility would be nearly eliminated, resulting in fewer traffic accidents, less pollutant emissions, and less noise. Suspension of renovation and construction activities would result in reduced noise levels and airborne $\mathrm{PM}_{10}$ concentrations. The elimination of wastes and fuel on the facility would prevent impacts to the environment from spills. 
The most substantial impacts under this alternative, however, would be adverse. Socioeconomically, the loss of up to 680 jobs would negatively affect the Grand Junction housing market, local tax base, vigor of many service industries, and well-being of the community in general. The mental well-being of the terminated employees and their families also would be adversely affected for several years, until new jobs could be acquired.

\subsection{Accident Analysis}

The DOE Office of NEPA Oversight (DOE 1993c) recommends that reasonably foreseeable accidents be analyzed in EAs so that readers may determine whether a proposed action has the potential for significant impacts. Three kinds of accident scenarios are analyzed in relation to GJPO facility operations: (1) an operational accident involving a single-container spill, (2) an accident involving a fire or explosion in the Hazardous and Mixed Waste Storage Unit, and (3) a worst-case accident involving spillage of the entire stock of chemicals in the Analytical Laboratory. The potential for these accidents to occur would be the same under the No Action Alternative and Proposed Action Alternative. Under the Shutdown Alternative, the potential for these accidents to occur would be negligible or nonexistent because chemicals and wastes would not be stored on the facility.

The scenarios and data discussed in this section were obtained from the DOE-GJPO Safety Assessment (DOE 1994a), which was prepared in accordance with DOE Order 5481.1B, Safety Analysis and Review System. In the accident analysis, Emergency Prediction Information (EPI) Code software was used to evaluate the atmospheric release of toxic substances.

\subsubsection{Single-Container Spill}

The most prevalent hazard at the GJPO facility is the presence of a large number of chemicals; the Analytical Laboratory stores and uses more than 2,000 different chemicals. The DOE-GJPO Safety Assessment (DOE 1994a) contains a list of these chemicals, chemical container sizes, and number of containers in inventory. Hazardous chemicals (e.g., benzene, hydrochloric acid, lead chromate, and mercury) are stored only in amounts expected to be used within the shelf life of the chemical or within the expected duration of the project or activity for which the chemical was obtained.

The most common chemical accident scenario would be one in which a chemical container is dropped to the floor of Building 20 and shattered. The chemical would be mixed with the atmosphere, drawn into the ventilation exhaust systems, and released to the atmosphere. At that point, the wind would carry the "cloud" to the off-site population. This scenario assumes that the entire contents of the largest container in inventory would be released to the atmosphere. In a real situation, this would not be 
possible because only a very small fraction of a chemical would become airborne as a result of a spill.

Results of the accident scenario modeling using EPI Code software indicated that none of the chemicals stored on the GJPO facility would adversely affect the nearest off-site population, which is 0.7 kilometer $(0.4$ mile $)$ from Building 20 . Adverse effects were determined by comparing modeled air concentrations with immediately-dangerous-to-lifeand-health (IDLH) levels, with 4 times the short-term-exposure-limit (STEL) values, and with 6 times the time-weighted-average (TWA) levels. The IDLH level is the maximum concentration from which one could escape, within 30 minutes, without any escapeimpairing symptoms or irreversible health effects. STEL values represent the maximum concentration to which a person should be continuously exposed for a period of 15 minutes (with a maximum of four such periods per day and at least 60 minutes between exposure periods). The TWA is the maximum concentration to which a person should be exposed during a normal 8-hour workday or 40-hour week.

The effects of a single-container spill also were determined for the on-site work force (defined as all GJPO personnel not working in Building 20), the responsible individual, and Building 20 occupants. Modeling results showed that none of the chemicals stored on the facility would result in an airborne concentration that exceeded IDLH, 4 times STEL, or 6 times TWA at a distance of 0.1 kilometer ( 100 yards) from the release point. In addition, none of the modeled concentrations exceeded IDLH in the building or in the room of the spill. Only lead chromate and hydrazine exceeded TWA in the building; several more chemicals exceeded TWA in the room of the spill. [Note: Hydrazine has since been removed from the laboratory's inventory.] Considering the relatively short time of exposure to the individual (either the chemical would be cleaned up immediately, or the individual would evacuate the room), the risk to the individual would be minimal. Likewise, the risk of exposure to building occupants would be minimal.

The primary accident mode for a single-container spill would be human error, which makes the probability of such an accident "likely," with an annual probability in the range of 0.1 to 1 per year. On the basis of modeling results, however, nearly all singlecontainer spills would have negligible effects on the responsible individual and building occupants and no effect on the off-site population and on-site work force. Additional mitigating factors such as the containment provided by Building 20, engineering controls such as fume hoods, mandatory personal protective equipment, and the immediate cleanup response would reduce the risks of exposure.

\subsubsection{Fire or Explosion in the Hazardous and Mixed Waste Storage Unit}

A second accident scenario involves a fire or explosion in the Hazardous and Mixed Waste Storage Unit (Building 42), which could result in a chemical or radioactive plume being carried by wind to the on-site work force or to the off-site population. EPI Code software was used to model the results of such a scenario. Typical waste types (which include hazardous, mixed, and radioactive wastes; see Section 3.1.7.1 for examples) and a 
maximum waste inventory ( 2400 gallons) were assumed in the model. For modeling radiological release rates, the DOE release fraction of $10^{-3}$ was applied to isotopes in the inventory. Modeled radiological values were compared to threshold values listed in Table A.1 in the Hazard Categorization and Accident Analysis Techniques for Compliance with DOE Order 5480.23, Nuclear Safety Analysis Reports (DOE 1992).

Modeling results showed that no chemicals exceeded IDLH at a distance of 0.1 kilometer from the release point. Only mercury exceeded any limit, and it exceeded the 4-timesSTEL value. All potential radiological releases were less than $1.0 \times 10^{-12}$ of the threshold values listed in Table A.1. Because of the transitory nature of fumes from a fire or an explosion, it is highly unlikely that an individual downwind of the release point would be adversely affected.

The Hazardous and Mixed Waste Storage Unit is constructed of metal siding on a concrete foundation and is not flammable. For a fire or an explosion to occur, a leaking or spilled drum of volatile or flammable liquid and an ignition source would have to be present. While it would be possible to have a leaking drum or a spilled container, the availability of an ignition source would be extremely unlikely. The building has a Class I, Division I electrical system and is equipped with an intrinsically safe heating system. Because of these factors, the annual probability of a fire or explosion in the storage unit would be less than $1.0 \times 10^{-5}$. The risk to an individual would be marginal, and the risk to the off-site population would be negligible.

\subsubsection{Worst-Case Accident, Earthquake}

The worst-case, foreseeable accident that could occur on the facility would involve the release of the entire stock of stored chemicals in Building 20. The most likely cause of such an accident would be an earthquake. EPI Code software was used to evaluate the effects of this scenario on the off-site population and the on-site work force not occupying Building 20 . Building occupants were assumed to die as a result of the structure collapsing on them.

Under the accident scenario, the entire contents of all chemical containers were assumed to be instantaneously disbursed at a height of 3 meters. Realistically, the likelihood of the entire contents getting disbursed would be extremely small. Building debris, intact shatter-resistant containers, and intact steel-storage cabinets would inhibit the release of many of the chemicals. Therefore, DOE release fractions from Hazard Categorization and Accident Analysis Techniques for Compliance with DOE Order 5480.23, Nuclear Safety Analysis Reports (DOE 1992) were used to quantify the amounts that would actually be released to the atmosphere. The model did not account for explosive chemical reactions that could occur from the mixing of chemicals, nor did it consider the plume height from an explosion, which could affect the diffusion of the chemical cloud.

Results of the modeling showed that none of the chemicals exceeded IDLH concentrations off site ( 0.7 kilometer downwind of Building 20 ). Because the wind would 
continue to transport the chemical plume downwind, total exposure to an off-site individual would be minimal. Health effects would range from no irritation to moderate irritation to the skin, eyes, and mucous membranes and other possible effects. Because of the short duration of exposure, only hypersensitive individuals would be at risk.

The maximum concentrations (measured at 0.1 kilometer from Building 20 ) to which onsite individuals could potentially be exposed exceeded those of the off-site population. However, none of the chemicals exceeded IDLH concentrations. For example, the modeled concentration for nitric acid, which has an IDLH concentration of $100 \mathrm{ppm}$, was $81 \mathrm{ppm}$. It would be possible, although unlikely, for an individual to incur adverse health effects from this temporary chemical exposure.

The probability of an earthquake toppling Building 20 would be about 0.001 , assuming that a $0.075 \mathrm{~g}$ (about "VI" on the modified Mercalli scale, which ranges from I [detectable only instrumentally] to XII [causing almost total destruction]) earthquake could destroy the building. The risk to the off-site population and to the on-site work force not housed in Building 20 would be minor. 


\subsection{List of Agencies and Persons Consulted}

Mesa County, Colorado (Mr. K. Rulf, Receiver at Mesa County landfill). Mr. Rulf provided information concerning the volumes of solid waste typically received by the Mesa County landfill.

U.S. Army Reserve, Grand Junction; Colorado (Mr. B. Gouldsberry, Unit Administrator). Mr. Gouldsberry provided information concerning the activities conducted on the U.S. Army Reserve area in the north end of the GJPO facility.

U.S. Department of Agriculture, Natural Resource Conservation Service, Grand Junction, Colorado (Mr. J. Currier, Supervisory Soil Conservationist). Mr. Currier confirmed that prime or unique farmland did not exist on or adjacent to the GJPO facility.

U.S. Department of Interior, Bureau of Land Management, Grand Junction District Office, Grand Junction, Colorado (Ms. S. Moyer, Wildlife Biologist). Ms. Moyer confirmed that the Uintah Basin hookless cactus, federally listed as threatened, had been observed in the Grand Junction area but was unlikely to be growing on or near the GJPO facility. 
page left

intentionally blank 


\subsection{References}

American Society of Heating, Refrigerating and Air-Conditioning Engineers, Inc., 1993. ASHRAE Standard, Energy-Efficient Design of New Low-Rise Residential Buildings, ASHRAE Publication Sales, Atlanta, Georgia.

Baker, D.A., and J.K. Soldat, 1992. Methods for Estimating Doses to Organisms from Radioactive Materials Released into the Aquatic Environment, PNL-8150, Pacific Northwest Laboratory, operated for U.S. Department of Energy by Battelle Memorial Institute, Richland, Washington.

Barker, C. E., 1995. Personal Communication, Financial Services, Rust Geotech, Grand Junction, Colorado, January 23.

Burm, R. J., 1992. Letter from Robert J. Burm, U.S. Environmental Protection Agency, Region 8, Denver, Colorado, to R. Eldon Bray, U.S. Department of Energy, Grand Junction Projects Office, Grand Junction, Colorado, dated July 28, 1992.

Currier, J., 1994. Personal Communication, Supervisory Soil Conservationist, U.S. Department of Agriculture, Soil Conservation Service, Grand Junction, Colorado, September 23.

40 CFR Part 61, Subpart H. U.S. Environmental Protection Agency, "National Emission Standards for Emissions of Radionuclides Other Than Radon from DOE Facilities."

40 CFR Part 61, Subpart M. U.S. Environmental Protection Agency, "National Emission Standards for Asbestos."

40 CFR Part 192. U.S. Environmental Protection Agency, "Health and Environmental Standards for Uranium and Thorium Mill Tailings."

40 CFR Section 261.4. U.S. Environmental Protection Agency, "Identification and Listing of Hazardous Wastes, Exclusions."

40 CFR Part 355. U.S. Environmental Protection Agency, "Emergency Planning and Notification."

40 CFR Part 370. U.S. Environmental Protection Agency, "Hazardous Chemical Reporting: Community Right-to-Know."

40 CFR Part 403. U.S. Environmental Protection Agency, "General Pretreatment Regulations for Existing and New Sources of Pollution."

40 CFR Part 761. U.S. Environmental Protection Agency, "PCBs Manufacturing, Processing, Distribution in Commerce, and Use Prohibitions." 
40 CFR Section 761.180. U.S. Environmental Protection Agency, "PCBs Manufacturing, Processing, Distribution in Commerce, and Use Prohibitions; Records and Monitoring."

40 CFR Section 761.205. U.S. Environmental Protection Agency, "PCBs Manufacturing, Processing, Distribution in Commerce, and Use Prohibitions; Notification of PCB Waste Activity."

40 CFR Part 763. U.S. Environmental Protection Agency, "Asbestos."

49 CFR Parts 101-178. U.S. Department of Transportation, "Transportation."

Gouldsberry, B., 1995. Personal Communication, Unit Administrator, U.S. Army Reserve, Grand Junction, Colorado, August 10.

Grand Junction Chamber of Commerce, 1995. Community Profile-1995, Grand Junction, Colorado.

Hightower, M. L., 1994. Personal Communication, Safety Coordination Technician; Health, Safety, and Security, Rust Geotech, Grand Junction, Colorado, September 27.

Hurd, J. D., 1994. Personal Communication, Security Specialist; Health, Safety, and Security, Rust Geotech, Grand Junction, Colorado, September 26.

International Conference of Building Officials, 1994. Uniform Building Code, Whittier, California.

Kelleher, C. R., 1994. Personal Communication, Manager, Technical Support, Field Assessments, Rust Geotech, Grand Junction, Colorado, October 11.

Mesa County, 1988. Conditional Use Permit Application and Certificate of Designation for Climax Uranium Mill Tailings Remedial Action Project in an Industrial and Agricultural Forestry Transition Zone-Climax Uranium Mill Site-Haul Route, Cheney Reservoir Disposal, Resolution No. MCM 88-30, Planning Department No. C11-88, Mesa County Courthouse, Grand Junction, Colorado.

Meyer, T., 1995. Personal Communication, Budget Analyst, Oak Ridge National Laboratory, Grand Junction, Colorado, January 23.

Morrow, L. F., 1995. Personal Communication, Contracts and Procurement, Rust Geotech, Grand Junction, Colorado, January 23.

Moyer, S., 1993. Personal Communication, Wildlife Biologist, U.S. Department of Interior, Bureau of Land Management, Grand Junction District Office, Grand Junction, Colorado, March 30. 
Price, J. E., 1994. Personal Communication, Air Quality Specialist, Rust Geotech, Grand Junction, Colorado, September 22 and October 13.

Rulf, K., 1995. Personal Communication, Receiver, Mesa County Landfill, Grand Junction, Colorado, October 20.

Rust Geotech, 1994a. Analytical Chemistry Laboratory Chemical Hygiene Plan, Grand Junction, Colorado.

Colorado.

, 1994b. Environmental Services Desk Instructions, Grand Junction,

, 1994c. Grand Junction Projects Office Facility, Grand Junction Projects Office Remedial Action Project, Monticello Mill Tailings Site Sampling and Analysis Plan for Environmental Monitoring, Grand Junction, Colorado.

Colorado.

, 1994d. Handbook of Petrology Laboratory Methods, Grand Junction,

,1994e. Radon/Environmental Sciences Laboratories Chemical Hygiene

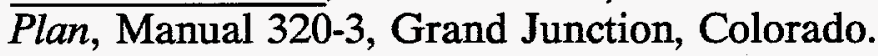

, 1994f. Radon Laboratory Procedures, Manual 320-4, Radon

Laboratory, Grand Junction, Colorado.

Junction, Colorado.

1994g. Stores, Property, and Transportation Desktop Manual, Grand

Junction, Colorado.

1995a. Environmental Protection Manual, Manual 102, Grand

, 1995b. Health and Safety Manual, Volume 2, Manual 103,

Radiological Control Manual, Grand Junction, Colorado.

Spears, C. F., and E. V. Kleven, 1978. Soil Survey of Mesa County Area, Colorado, U.S. Department of Agriculture, Soil Conservation Service, in cooperation with Colorado Agricultural Experiment Station, Grand Junction, Colorado.

10 CFR Part 835. U.S. Department of Energy, "Occupational Radiation Protection."

10 CFR Section 1021.330. U.S. Department of Energy, "National Environmental Policy Act Implementing Procedures; Programmatic (including Site-Wide) NEPA Documents."

29 CFR Part 1910. U.S. Department of Labor, "Occupational Safety and Health Standards." 
29 CFR Section 1910.95. U.S. Department of Labor, "Occupational Safety and Health Standards, Occupational Noise Exposure."

29 CFR Section 1910.1000. U.S. Department of Labor, "Occupational Safety and Health Standards, Air Contaminants."

29 CFR Section 1910.1001. U.S. Department of Labor, "Occupational Safety and Health Standards, Asbestos."

29 CFR Section 1910.1450. U.S. Department of Labor, "Occupational Safety and Health Standards, Occupational Exposure to Hazardous Chemicals in Laboratories."

29 CFR Part 1926. U.S. Department of Labor, "Safety and Health Regulations for Construction."

29 CFR Section 1926.58. U.S. Department of Labor, "Safety and Health Regulations for Construction, Asbestos."

U.S. Army Corps of Engineers, 1976. Flood Hazard Information, Colorado River and Tributaries, Grand Junction, Colorado, prepared for the city of Grand Junction and Mesa County, Sacramento District Corps of Engineers, Sacramento, California.

U.S. Department of Energy (DOE), 1986. Final Environmental Impact Statement, Remedial Actions at the Former Climax Uranium Company Uranium Mill Site, Grand Junction, Mesa County, Colorado, DOE/EIS-0126-F, Albuquerque Operations Office, UMTRA Project Office, Albuquerque, New Mexico.

, 1989. Final Remedial Investigation/Feasibility Study-Environmental Assessment for the U.S. Department of Energy Grand Junction (Colorado) Projects Office Facility, DOE/EA-0402, prepared by UNC Geotech for U.S. Department of Energy Grand Junction Projects Office, Grand Junction, Colorado.

,1990a. Declaration for the Record of Decision and Record of Decision Summary-Grand Junction Projects Office Remedial Action Project, Idaho Operations Office, Grand Junction Projects Office, Grand Junction, Colorado.

, 1990b. GJPO Waste Minimization Program Plan, prepared by UNC

Geotech for U.S. Department of Energy Grand Junction Projects Office, Grand Junction, Colorado.

, 1991. Environmental Regulatory Guide for Radiological Effluent Monitoring and Environmental Surveillance, U.S. Department of Energy, Assistant Secretary for Environment, Safety, and Health, Washington, D.C. 
DOE, 1992. Hazard Categorization and Accident Analysis Techniques for Compliance with DOE Order 5480.23, Nuclear Safety Analysis Reports, DOE-STD-1027-92, Washington, D.C.

, 1993a. Administrative Record: Grand Junction Projects Office Remedial Action Project, Direct Truck Haul of Residual Radioactive Material to the Cheney Repository, GJP-93-048, Albuquerque Operations Office, Grand Junction Projects Office, Grand Junction, Colorado.

, 1993b. Radiological Surveillance of Biota at the Grand Junction Projects Office Facility, Internal Technical Report ES-GJ-93-17, prepared by Rust Geotech for U.S. Department of Energy Grand Junction Projects Office, Grand Junction, Colorado.

,1993c. Recommendations for the Preparation of Environmental Assessments and Environmental Impact Statements, Office of NEPA Oversight, Washington, D.C.

, 1993d. "Waste Minimization and Pollution Prevention Awareness Plan," in Appendix B of Environmental Protection Manual, prepared by Rust Geotech for U.S. Department of Energy Grand Junction Projects Office, Grand Junction, Colorado.

, 1994a. DOE-GJPO Safety Assessment, prepared by Rust Geotech for U.S. Department of Energy Grand Junction Projects Office, Grand Junction, Colorado.

, 1994b. GJPO Emergency Preparedness and Response Plan, prepared by Rust Geotech for U.S. Department of Energy Grand Junction Projects Office, Grand Junction, Colorado.

, 1994c. "National Environmental Policy Act Documentation for the Proposed Action to Perform Remedial and Demolition Type Activities on Radiologically Contaminated Buildings at the U.S. Department of Energy Grand Junction Projects Office (GJP-94-031)," Administrative Record for Compliance with DOE NEPA Process, Albuquerque Field Office, Grand Junction Projects Office, Grand Junction, Colorado, August 15, 1994.

, 1995a. Draft Waste Management Programmatic Environmental Impact Statement, Office of Environmental Waste Management, Washington DC.

, 1995b. Final Report of the Decontamination and Decommissioning of the Exterior Land Areas at the Grand Junction Projects Office Facility, GJPO-GJ-13, prepared by Rust Geotech for U.S. Department of Energy Grand Junction Projects Office, Grand Junction, Colorado. 
DOE, 1995c. First Annual Monitoring Report for the U.S. Department of Energy Grand Junction Projects Office Wetland Mitigation Project, prepared by Rust Geotech for U.S. Department of Energy Grand Junction Projects Office, Grand Junction, Colorado.

, 1995d. GJPORAP Health and Safety Plan, prepared by Rust Geotech for U.S. Department of Energy Grand Junction Projects Office, Grand Junction, Colorado.

, 1995e. Grand Junction Projects Office Facility, Grand Junction Projects Office Remedial Action Project, Monticello Mill Tailings Site Environmental Monitoring Plan, prepared by Rust Geotech for U.S. Department of Energy Grand Junction Projects Office, Grand Junction, Colorado.

, 1995f. Grand Junction Projects Office Proposed Site Treatment Plan, prepared by Rust Geotech for U.S. Department of Energy Grand Junction Projects Office, Grand Junction, Colorado.

, 1995g. Performance Objective for Certification of Nonradioactive Hazardous Waste, prepared by Rust Geotech for U.S. Department of Energy Grand Junction Projects Office, Grand Junction, Colorado.

DOE Order 4330.2D, In-House Energy Management, Washington, DC.

DOE Order 5400.1, General Environmental Protection Program, Washington, DC.

DOE Order 5400.5, Radiation Protection of the Public and the Environment, Washington, DC.

DOE Order 5480.3, Safety Requirements for the Packaging and Transportation of Hazardous Materials, Hazardous Substances, and Hazardous Wastes, Washington, DC, and Albuquerque Operations Office.

DOE Order 5480.5, Safety of Nuclear Facilities, Albuquerque Operations Office.

DOE Order 5481.1B, Safety Analysis and Review System, Washington, DC, and Albuquerque Operations Office.

DOE Order 5820.2A, Radioactive Waste Management, Washington, DC.

DOE Order 6430.1A, General Design Criteria, Washington, DC.

Wiesner, G., 1995. Personal Communication, Budget Analyst, U.S. Department of Energy, Grand Junction Projects Office, Grand Junction, Colorado, January 23. 


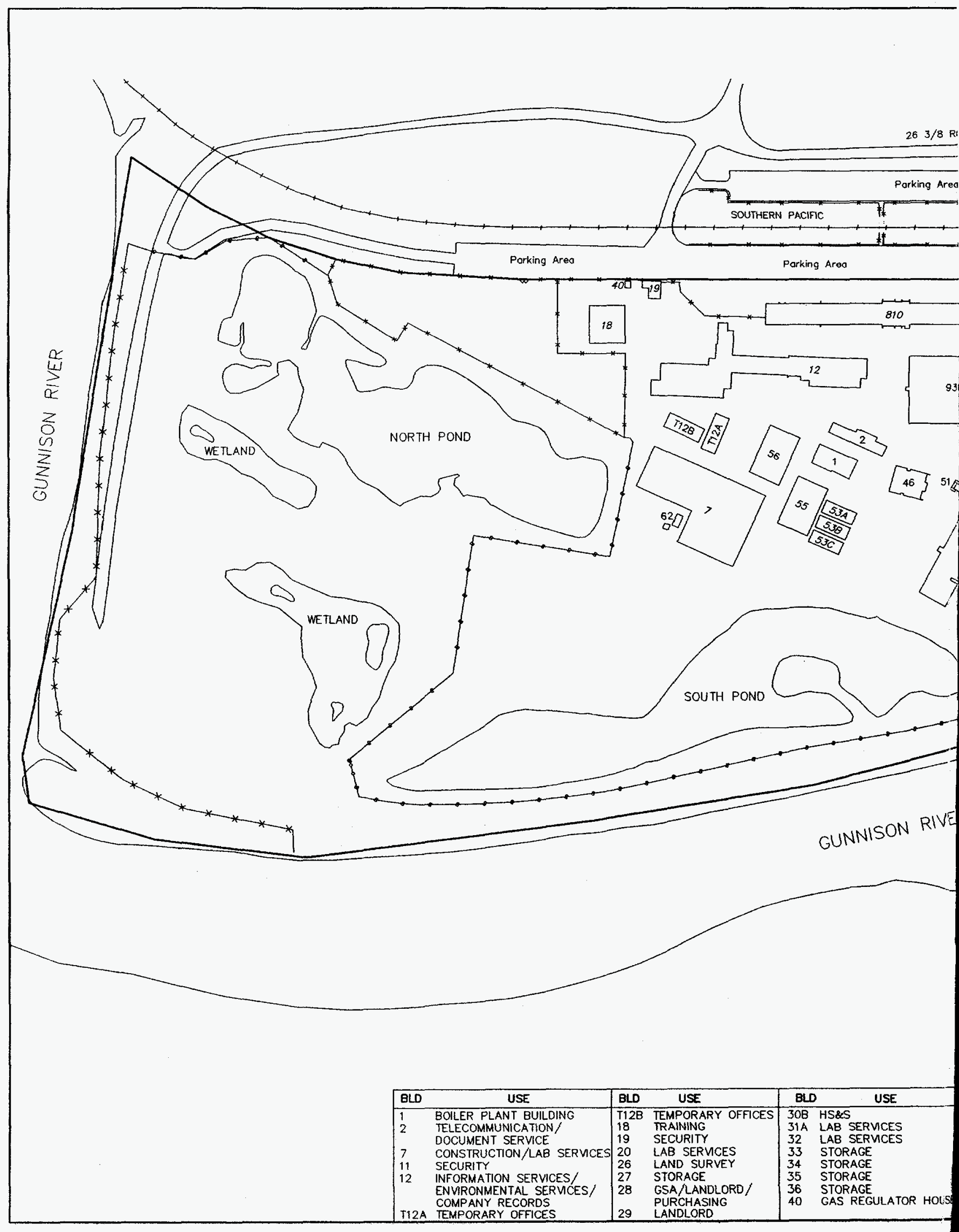


page left

intentionally blank 
